

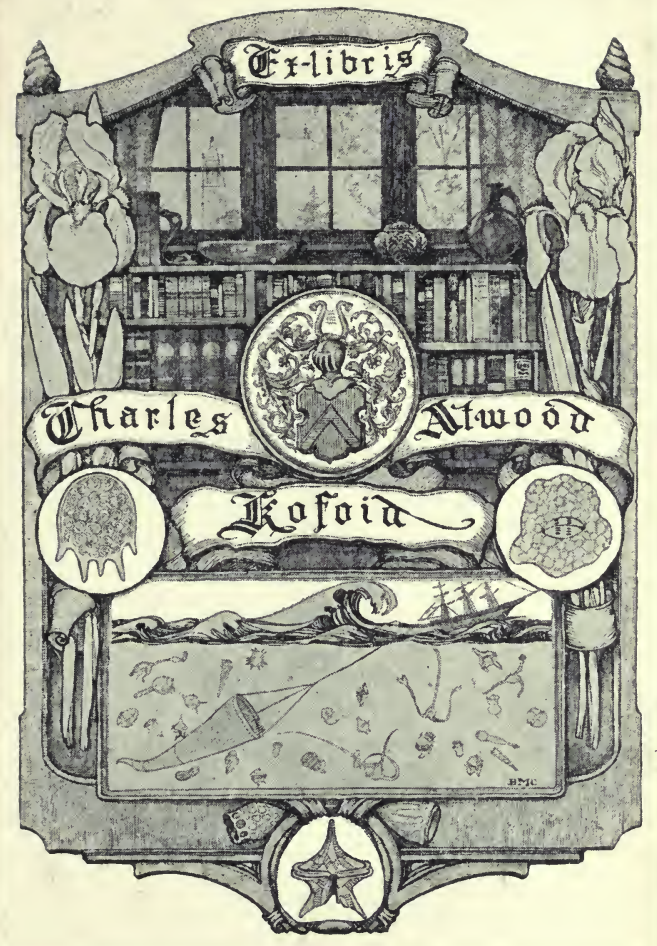




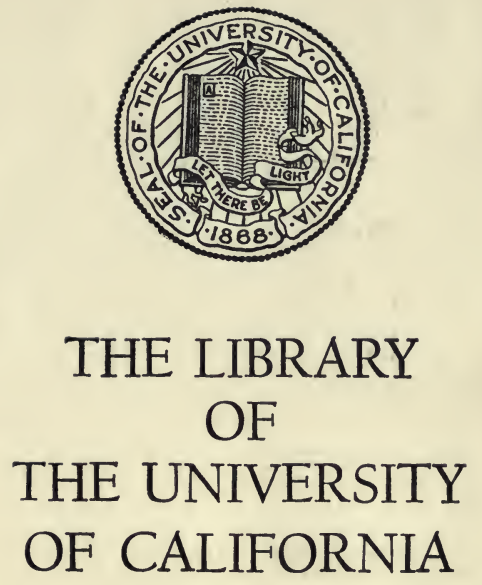

PRESENTED BY

PROF. CHARLES A. KOFOID AND MRS. PRUDENCE W. KOFOID 


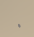

1

Y

,

- 1 

Digitized by the Internet Archive in 2007 with funding from Microsoft Corporation 


\section{THE ANGLER'S GUIDE}

TO TIIE

RIVERS \& LOCHS OF SCOTLAND. 


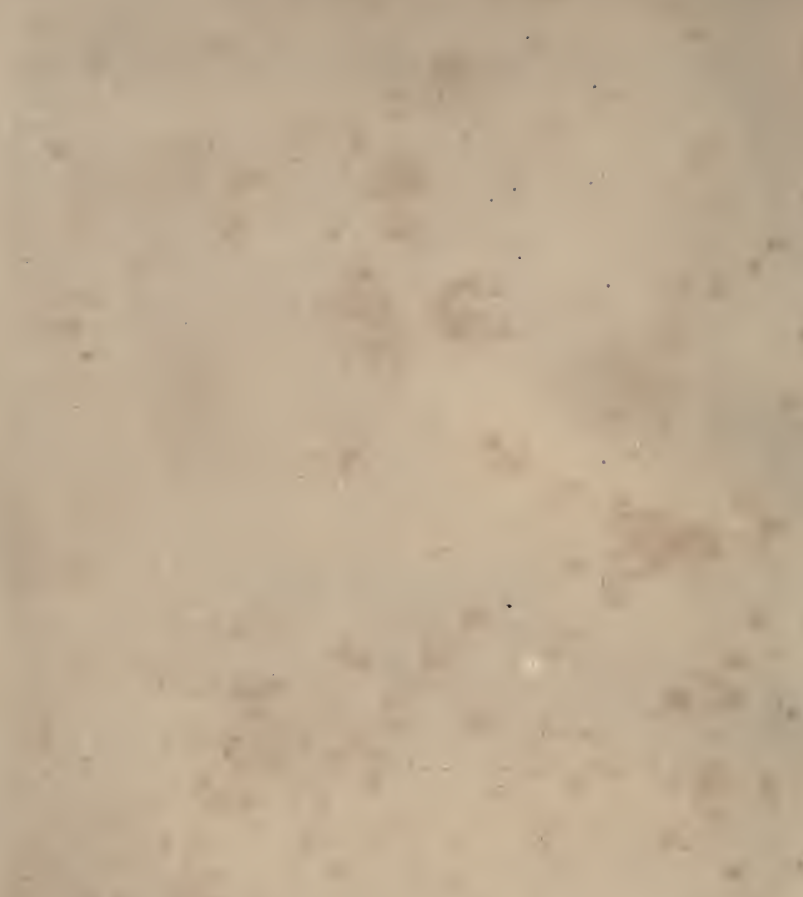

$$
\begin{aligned}
& \text { n } \\
& =\frac{1}{2}
\end{aligned}
$$

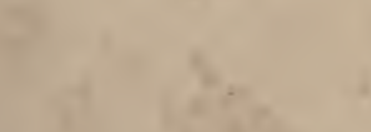

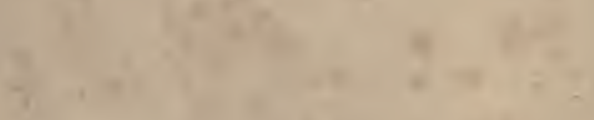

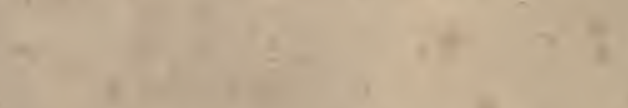

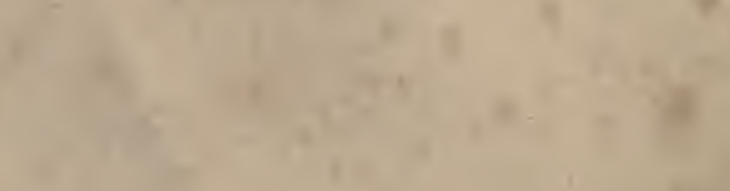


$+$

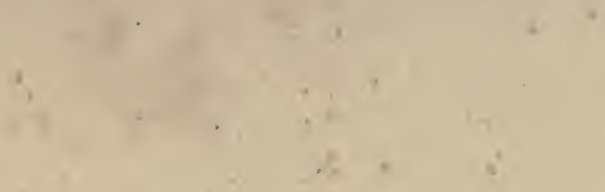

4

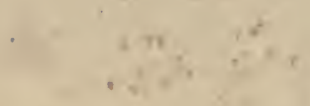

$\ln ^{2+1}+2$

$4, t^{2}+4,45$

$$
\text { c) }
$$

$$
+
$$




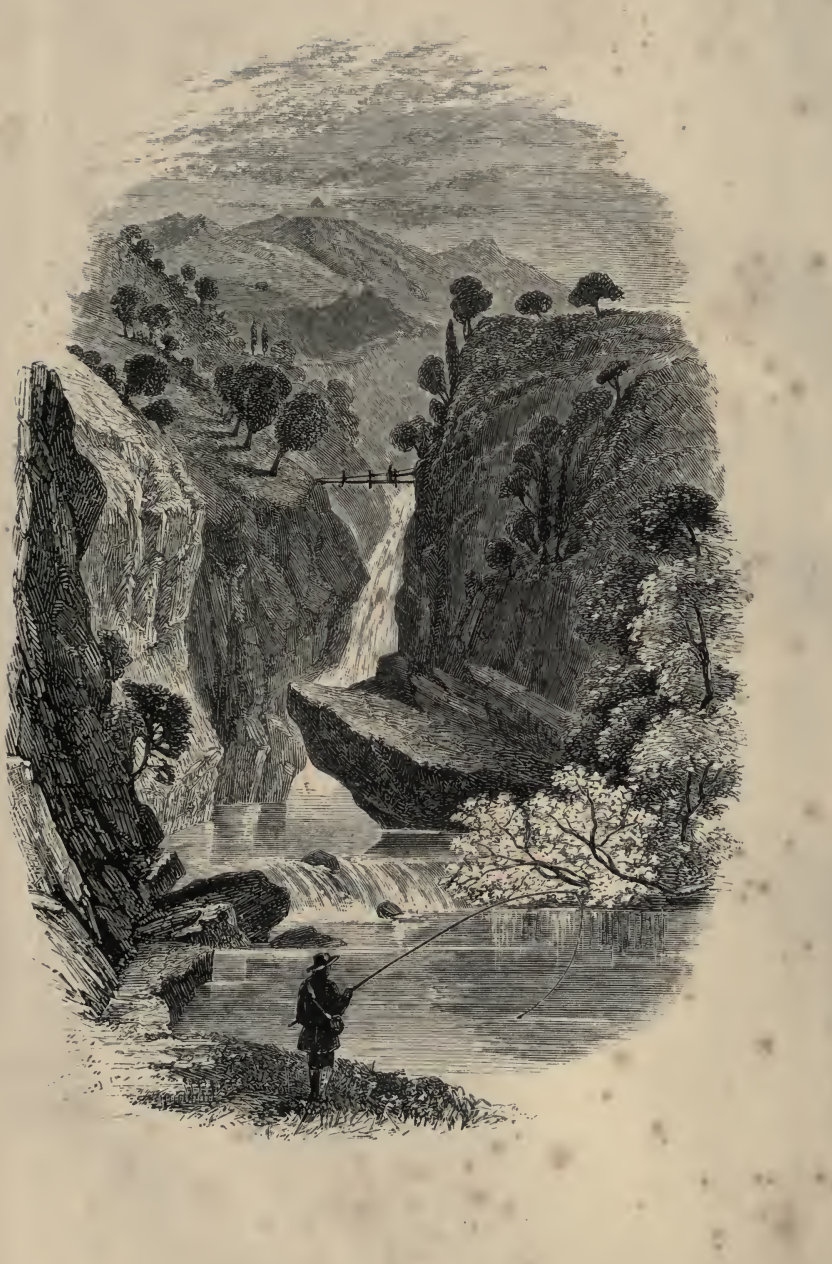




\section{THL \\ ANGLER'S GUIDE}

TO THE

\section{RIVERS \& LOCHS OF SCOTLAND.}

$$
\text { BY }
$$

ROBERT BLAKEY,

$\triangle O T H O R$ OF

"The Ansler's Guide to the Rivers and Lakes of England and Wales:"

" Hints on Angling:" “ The History of the Philosophy of Mind ," \&cc., \&cc.

\section{G L A S GO W :}

THOMAS MURRAY \& SON. JOHN MENZIES, EDINBURGH.-DAVID BOGUE, LONDON. MDCCCLIV. 


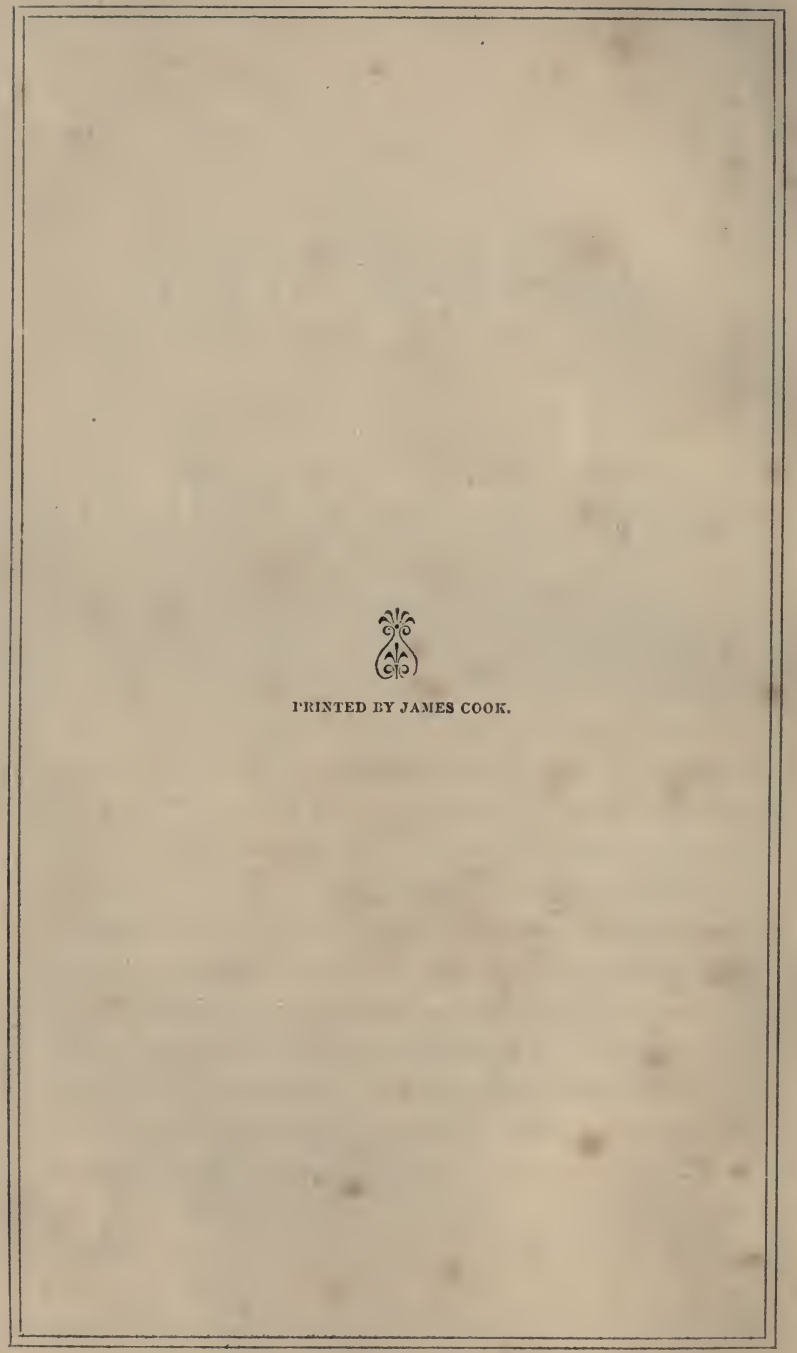




\section{PREFATORY REMARKS.}

ANGLING is, unquestionably, one of the most ancient arts or amusements of which we have any record. It is mentioned in the books of the Old Testament. It is engraved on Egyptian remains of three thousand years old; and, in the monuments from Nineveh, recently deposited in the British Museum, we have a representation, almost as large as life, of a man angling, with a rod and line, and with a fishing-creel on his shoulders, precisely similar in shape to those we use in Great Britain at the present day. The art is mentioned by Herodotus, one of the earliest Greek historians ; and Theocritus, a Grecian angler, who flourished B.C. 270, treats of his favourite sport in a poem of considerable length. The Romans fished with net and hook, as we do at present; and a caricature of angling has been found among the remains of the City of Herculanæum. 
vi

From the Christian era to the discovery of printing, there were many works written on the piscatory art; most of them have, however, been lost, or are now mouldering in manuscript in the chief public libraries of France, Italy, Spain, Iolland, and other northern countries of Europe. Since the establishment of printing to the present day, there have not been fewer than from five to six hundred works written on the art, in the several kingdoms of the European Continent; more than onehalf of the number belonging to the English literature on the subject.

But our own nation has taken a decided lead, from the earliest times, in disseminating a knowledge of rod-fishing in every quarter of the globe. There is scarcely a section of its surfacc, on which a Briton has set his foot, where the art is not known. There are angling clubs or societies in every country of Europe. The art is practised in all our extensive Indian territories; throughout the colony of the Cape of Good Hope; in various portions of Australia; and in the Canadas. In all the United States of $\Lambda$ merica,-particularly in those of New England,-rod-fishing is generally followed as an amusement, and has been eloquently written about, as is manifest from the treatises and occasional papers on the subject, which have issued from the pens of Washington Irving, Dr. Smith, Dr. Beecher, and the late Hon. Daniel Webster. We see from the American newspapers that angling societies are formed in districts that lie a thousand miles west of the city of New York. In fact, the Anglo-Saxon race are destined to make angling a common and rational recreation all over the world. In their diversified migrations, a fishing-rod is now 
vii

almost as necessary an appendage to their outfit as the rifle or the pistol.

As a proof of the vast increase in the number of anglers, both in this and other countries, we may refer to the fact, that forty years ago, there were not more than six or seven fishingrod and tackle-makers and sellers in the metropolis; now, there are between forty and fifty; and no small portion of the business of these establishments, is the exportation of rods and tackle to almost every part of the civilized world.

In reference to the present small work, on the Rivers and Lochs of Scotland, now offered to the public, I have little to say; nor is there much required. I have told my own story, I hope in plain and simple language, and in my own fashion. I hold the opinion that angling should be lightly treated, and that nothing tends to depress the art, and make it a dull and lifeless thing to be written about, than the practice of compiling treatises upon it, like Parliamentary Blue Books, full of statistical and foreign matters, not in fair keeping with the end or object of rod-fishing. That end is ehiefly to open out and stimulate the contemplative and reflectire powers of the inward man; and to make him feel the delightful pleasures flowing from a free and direct intercourse with external nature. Unless this grand end be kept in view, and all our written dissertations upon it have a reference to it, angling is not worth a moment's consideration. The moral and thoughtful habits ought to be the primary objects we aim at forming and strengthening; in every mode of describing and recommending the art. Besides, minute matters of detail can be of no real service in the acquirement of the art. No man can be 


\section{viii}

made an angler by books, any more than he can be made a shoemaker, a joiner, or a mason. It is a practical art, depending upon experience and imitation. What we have to do, therefore, in writing works upon the subject is, to induce men, and more especially youthful ones, to become anglers; to lead them to contemplate the recreation as one, both physically and morally, of a healthful and improving character. This must ever be the chief end and recommendation of the art, and a test of the value of works written upon it.

February 2, 1854. 


\title{
ANGLING RIVERS AND LAKES
}

\author{
or \\ S C OT L A N D.
}

"Once more, O North! I view thy winding shores, Climb thy bleak hills, and cross thy dusky moors; Impartial view thee with a heedful eye, And still by nature, not by censure try. England, thy sister, is a gay coquette, Whom art enlivens and temptations whet; Rich, proud, and wanton, she her value knows, And in a conscious warmth of beauty glows. Scotland comes after, like an unripe fair, Who sighs with anguish at her sister's air, Unconscious that she'll quickly have her day, And be the toast when Albion's charms decay."

AARON HILL.

\section{INTRODUCTORY OBSERVATIONS.}

As the angler travels northward, and turns his back on the rich and variegated scenery of England, he discovers, on entering Scotland, a comparatively bleak and open country, thinly ornamented with wood and hedgerows, and where high and naked mountains aspire to a towering elevation, and present a cold, yet romantic picture, varied by numerous streams and water-falls between the rocks. The whole of the northern portion of the kingdom is 
covered with high mountains, with the exception of Caithness, the coast of Sutherlandshire, and a portion of Ross-shire. In the centre of the country there are high and mountainous grounds, but there are here intervening valleys of great fertility and beauty. In the South, except towards the Eastern coast, elevated and wild tracts of land prevail, especially from Glenluice to the Cheviot Hills. The lofty nature of Scotland generally gives rise to numerous precipitate streams, forming also many occasional lakes or lochs, the waters of which, as well as the rivers, are remarkably limpid. Altogether, the disciples of the "gentle art," who ramble from the South, will readily perceive that the scenery, as well as the manners and customs of the people, are of a different cast from what are to be found in England.

As I have elsewhere said,* there is, perhaps, no. country in Europe, taking all things into accountits comparatively limited extent, number and length of streams, size of lakes, \&c., \&c.-so favourable for the purposes of the angler, as Scotland. Every little river, burn, torrent, or creck, however narrow its bed or limited its range, is full of fine trout; whilst at the same time the whole country abounds with immense quantities of the varicties of the noble salmon; the fish, above all others, best qualified to afford the angler the most heart-stirring and refined amusement to which his art can aspire.

* See IIints en Angling; by Palmer ITackle, Esq. London, tst6. 


\section{3}

Scotland being but a small country, bounded on all sides but one by the ocean; and being, moreover, very hilly and mountainous, all the waters which flow from its bosom have an easy, short, and rapid descent to the sea; and these cireumstanees are favourable to the prolific powers of the trout and salmon, and are the cause of those remarkable facilities which the rod-fisher enjoys in every portion of the "land o' cakes." There are here no long tracts of flat country, through which drowsy rivers meander with a sluggish motion, and thus become comparatively unfit for the higher and more skilful species of angling; but everything is rushing, rapid, clear, and sparkling, from the banks of the Tweed to John-o'-Groat's house. In every direction, and in beautiful variety, you fall in with the fine majestic river, the limpid bubbling stream, the mountain torrent, and the silvery rivulet, with their countless millions of salmon and trout, which revel in unbounded freedom in their delicious waters, without a rival, and unconscious of any enemy, save the tyrant-man.

But, rich as Scotland is in piscatory resourees and facilities, this is not her only claim upon the attention of the angler. There is a remarkable degree of case and pleasure in angling in this country, arising from another source. Scotland affords, in the first place, a comparatively open, and free ficld for the pursuit of this delightful and national amusement. Impediments arising from exclusive reserves, and pet waters, are but of rare occurrence; and the fair 
and gentlemanly sportsman will experience but little interruption from obstructions of this description. Indeed, it may almost be said, that nuisances of this nature are entirely unknown in Scotland. On this account, all the morements of the wanderer are free and unfettered. The sport of angling is so universally indulged in, that there is not a town or village in the whole eountry, situated near a river or stream of any kind, in which you will not meet with anglers of first-rate pretensions; - men, too, who are far above any mean feeling of petty jealousy at your intrusion into their accustomed haunts, or your participation in their farourite amusement. In fact, despicable and unworthy feelings or sentiments of this kind ean never be encouraged or even generated in a country where every mere boy ean go out and fill his creel with the finest trout in a few hours, and perhaps bring home half-a-dozen prime and delicious salmon, or salmon trout, into the bargain.

But free and unrestrained as the angler's personal movements are in this country, compared with England, they are not more so than the movements of his tackle. Here there are scarcely any impediments to the full and free use of the fly, arising from trees, or bushes, or underwood of any kind. The country is remarkably open; and the rushing and impetuous waters of the fresh streams, scoop out for themselves such broad and eapacious beds, that ample room is afforded for the full swing of the very longest line which a man can use with a rod. You may, in many cases, ramble down the banks of 


\section{5}

a river for several miles, and never stumble on a single tree or bush.

Another great advantage which the angler enjoys in Scotland arises from the fact, that he need not be so fastidious about the choice of his flies as he would require to be, or rather he would be compelled to be, in other countries, by the mere form of custom and prejudice. If you have any tolerably well made flies, and the waters are in good order, you may as surely calculate upon a good day's sport, as upon the appearance of to-morrow's sun. In a word, disappointment can never be permanently, or even generally, experienced in this splendid fishing country.

To impart something like orderly arrangement to our descriptions and remarks, we shall ideally divide the country into four chief compartments, making the City of Glasgow the centre spot of our imaginary fishing excursions. The First division is that of the South and South-Eastern; the Second, the SoutII-W Estern; the Third, the North and Norti-Westers; and the Fourth, the EAstern and North-EAstern. 


\section{PART I.}

\section{SOU'H AND SOUTH EASTERN DIVISION,}

Comprehexding the Counties of Berwickshire, Peebleshire, RoxBurghsmire, Selkirkshire, Haddingtoxshre, Edixburghshrre, LINLITHGOWSHIRE, AND LAXARKSHIRE.

13 E R W I C K S H I R E.

THE RIVER TWEED.

"I've seen the smiling primrose flower Among the braes of Yarrow;

I've felt the cutting winds of Mareh Among the hills of Barra:

I've wander'd Scotland o'er and o'er, From Beauly to the Reed,

But the bonniest spot to throw a line, Is the bonny-bonny Tweed."

THe Tweed is, beyond all question, the finest river in Scotland for either trout or salmon; nay, we may almost venture to add that, take it as a whole, there is no river like it in all Europe. The angler can fish it with the fly perfectly unmolested, from its source to its mouth. During the first thirty miles of its course, scarcely a bush or a tree is to be seen; nothing but the limpid stream winding its murmuring way among the hills of considerable elevation, in many cascs rounded as in a lathe, and corered 


\section{7}

with the loreliest verdure to their very summits. To an eye long familiarised to the soft and rich, but comparatively tame scenery of merry England, a ramble along the banks of the Tweed, in this section of its course, will afford a novel and truly delightful treat. Fine rippling rushing streams, as clear and transparent as the purest erystal, will attract the enraptured angler every fifty or sixty yards on his route; whilst the broad channelled bed of the river, free from bush or twig, or impediment of any kind, will afford him erery possible facility for easting his line, and landing his fish. If there be a single breath of wind moving about these romantic hills, it soon frisks upon the surface of the glassy waters, so that, even in the brightest weather, the industrious angler can scarcely be disappointed of his sport. The supply of fish seems to be inexhaustible, for from 16 to 20 dozen of trout, with a goodly sprinkling of salmon, are no uncommon results of a single day's work by an expert and perserering sportsman.

Another great advantage which the Tweed possesses, as a fishing river, to the general mass of anglers, arises from the cireumstance, that all her tributary streams afford an almost endless succession of splendid sport. They are all supplied in rich abundance with trout and salmon; and as they flow from many opposite directions, they afford to the inhabitants of widely separated sections of the kingdom, the opportunity of enjoying the most delightful amusement in all parts of their waters. But, good as these tributary streams unquestionably are, as 
experience will prove them to be, they are still not to be compared with the parent water. The angler will be compelled to acknowledge that the Tweed stands unrivalled, and that there are few streamswe may almost say none-which can compete with this delightful fishing river.

We have angled the Tweed several times, from its earliest risings to the town of Berwick. We have likewise fished sections of it, by three different routes. The first is from the source to the sea. This is the best, at least to our fancy. We never like wandering up a river, and could give, if necessary, a thousand and one reasons for not liking to do so. But, should an angler come from the South, by way of Carlisle, to try his luck in the Tweed, then let him stop at the Elvanfoot station, on the Caledonian Railway, and walk over to the Tweed, which he will find among a cluster of alpine mountains, at about six miles' distance. Or, should he be at the village of Moffat, let him find his way to the Shaw's Inn, or Tweedshaws, as it is often ealled, and here he will meet with the river in its infant struggles through the mountain passes, follow it down, making such daily advances as his pleasure or time may dictate. We promise him, if he has the pure and simple feelings of a real angler, and has a mind susceptible of being affected with the sublimities and beauties of nature, he will not find that his labour has been ill requited.

We have gone by another route to the Tweed. We have traversed, starting from Carlisle, the vale 
of the Teviot, and reached the main river at Kelso. We have likewise set off from Berwick, and gone to Coldstream or Kelso by railway, and thrown a line on some of the intervening sections of the Tweed. Anglers from Edinburgh may reach the Tweed by Melrose, and those from Glasgow by way of Biggar. Circumstances must guide the angler as to the eligibility of each of these routes.

But supposing that a tourist wishes to ramble down the entire river, then he may commence fly fishing for trout, soon after he leaves Twcedshaws. In the spring, if it has been long very dry weather, the streams are rather too small and clear to do much execution, till you get below the Crook Inn. Here the water widens a little. and gets fuller and decper. We meet with longer reaches of still water, in which fish take shelter. They are, however, but small fish in this part of the river, and salmon and large bull trout are but seldom caught by rod. There are very fine streams and long pools of water from-the Crook to the junction of the Biggar water with the Tweed.

The Heartstone mountain, near the Crook Inn, is a magnificent object. The river runs here through the hills in great beauty. Many anglers make the village of Broughton their head quarters in fishing this section of the Tweed. It is about a mile and half from its banks, and there is a good inn, long established, ealled the II'Queen Arms, where there is good fare at reasonable prices. This village is seven miles from the Crook, and fourteen from Tweed- 
shaws. As we come down the hill from the village, and eatch a first glanee of the Tweed, the prospect is very imposing. On every side lofty hills present themselves; and the farm houses, and well cultivated fields, round their base, and the plantations which skirt the mansion of Tweedy House, furnish one of the most beautiful sights that any country can boast of.

The Biggar water, which enters here into the Tweed, is a fair fishing stream; the trout not numcrous, but rather large, and of rich quality. Worm fishing, in the hot and dry season of the year, is often practised here with great success. The brandling is the best bait, and next to it is the common red worm.

We have always found, in angling for trout in these higher sections of the waters of the Tweed, that in the months of March, April, and May, large flies are the most successful. They should likewise be of a lightish colour, with good sized wings. The woodeock wing, with hare's ear body, is a general farourite with the resident anglers in these localities.

From the entrance of the Biggar to the village of Stobo, there are some delightful angling streams, and reaches of still water. The rillage is pleasantly situated. The parish chureh is said to be full five hundred years old. Michel de Dunde, the rector of it, swore fealty to Edward I., at the town of Berwick, on the 2d August, 1296 . The scenery in the neighbourhood is particularly interesting. The hills 


\section{1}

are of moderate elevation, well wooded, and neatly arranged. The valleys are in the highest state of eultivation, and the antique church stands by the margin of a sthall stream, which pours its limpid waters into the main river. The burial ground, containing the mouldering ashes of many generations, is of great antiquity. A more swcetly sequestered spot it would be difficult to find.

There is a magnificent view obtained from the top of Dramore Hill, in this neighbourhood, over a spacious plain, which lies at the bottom of a deep basin, around which the Tweed winds its path. Not far off is the grave of the famed prophet, Merlin, who flourished in the sixth eentury.

The river Lyne enters the Tweed at Barnes. This is a delightful fishing tributary of the main water, and has a run of about twenty miles. Its streams are gushing and rapid, with deep holes and eddies. When the water is in order in summer-that is, is not too small and clear-there is excellent sport to be obtained. We have often taken large fish out of it, with red worm, in bright sunny days, when the fly was useless. Trolling, after a freshet, is deadly in this stream. The Tarth will afford a good day's angling when in full trim.

The Manor river enters the Tweed a little before it passes Neidpath Castle ; a most beautiful object in the general landscape. There is, at certain times, capital trout fishing in this tributary. The whole of the river seenery is here of the most fascinating 


\section{2}

character, and has often brought to our recollection the lines of the poet Thompson :

" And here awhile the muse,

High hovering o'er the broad cerulean scene,

Sees Caledonia in romantic riew;

Her airy mountains, from the waving main

Invested with a keen diffusive sky,

Breathing the soul acute; her forests huge,

Incult, robust, and tall, by nature's hand

Planted of old; her azure lakes between,

Pour'd out extensive, and of wat'ry wealth

Full ; winding deep and green, her fertile vales;

With many a cool, translucent, brimming flood

Wasl'd lovely, from the Tweed (pure parent stream)

To where the north-inflated tempest foams

O'er Orca's or Betubium's highest peak."

Peebles is a fine angling station on the Tweed. The river presents in every locality the finest ranges of angling water. The small tributary ealled the Eddleston runs into it at this town. This feeder abounds with small trout; and after a fresh in summer the angler may fill his basket with them in a few hours. We once tried the red-worm in its waters, when very low, and in the brightest weather, and took about six dozen out of it during the afterternoon. But few of them were more than a quarter of a pound in weight.

There is much to interest the lover of fine scenery, and the antiquary, about the town of Peebles, and the banks of the Tweed, above and below it. The most conspicuous object is Neidpath Castle, which is one among many of the strong castles erected in 
former days in this part of the kingdom against the incursions of the English marauders. These buildings were in the shape of square towers, three stories in height; the lowest one, on the ground floor, being vaulted, was commonly appropriated for the reception of cattle and horses in times of danger. These towers of refuge are placed alternately on each side of the river, and eommand a view of each. A fire kindled on the top was the ordinary signal of alarm, and by this simple means a large extent of country was readily called into hostile activity.

\section{" $\mathrm{A}$ score of fircs, I ween,}

From height, and hill, and cliff were seen,

Each with warlike tidings fraught,

Each from each the signal caught;

Each after each they glanced in sight,

As stars arise upon the night,

They gleam'd on many a dusky tarn,

Haunted by the lonely earn,*

On many a cairn's grey pyramid,

Where urns of mighty chiefs lie hid."

\section{- Lay of the Last Minstrel.}

Following, with rod in hand, the course of the river, on its northern banks, we pass a succession of country seats, the grounds about which are cultirated with singular care and neatness. The fishing waters, all the way down to Innerleithen, a distance of six miles from Peebles, are of the most farourable and inviting kind, both for salmon and trout.

Inverleithen has, of late years, become quite a

* Scottish Eagle. 
fashionable place for anglers and tourists. Its situation is both healthy and beautiful. The Quair, and the Leithen, both tributaries of the Tweed in this locality, are full of small trout, which are best obtained after a flood, when their waters have subsided a little, and have assumed an ale colour. We have seen both these streams nearly dry, in certain seasons of the year.

Leaving Innerleithen, and passing down the Tweed, we come to Caddon Water, a feeder to the main river, containing small trout in great quantities. The country is magnificent in every direction, and the fishing in all the various localities of the Tweed, is first rate. In the height of the angling season-that is, from the middle of Narch till the month of June-we find every bit cottage by the river side, from Peebles downwards, that can muster a bed of any kind, occupied by some piscatory amateur. It is often amusing to see to what personal inconveniency, in the way of lodging, men of rank and fortune will put themselves, in order to pursue their favourite sport.

We shall now, for a short time, leave the "bonny bonny Tweed," and make an excursion from its fertile and beautiful banks, to other scenes, not less interesting, and fruitful both of sport and serious and profitable contemplation. We shall make an imaginary trip to Selkirk, which lies at a short distance from the part of the Tweed we are now at. It is a capital fishing station, with an interesting looking country around it. The tour we purpose 


\section{5}

taking the reader is to fish the Yarrow and the Ettrick, two considerable feeders of the main river, and which jointly pour their waters into it, a little above Abbotsford.

Well, the distance from Selkirk to Moffat is thirtyfour miles. No coaches, nor railways, nor anything save the limbs, can assist us. Shall we ascend the Yarrow, and come down by the Ettrick, or aseend the Ettrick, and deseend by the Yarrow? It is Hobson's choice; we decide for the first. We leave Selkirk, and after about a two miles' walk, arrive at the entrance of the Yarrow into the Ettrick. The most magnificent scenery all around, and the landscape down the united streams, with Selkirk in the distanee, is very imposing.

A portion of the Yarrow is preserved for the first few miles after its junction with the Ettrick, but when the angling tourist reaches its free waters, near Broadmeadows, he will not be disappointed of a fair share of sport. But we must confess that the Yarrow is not quite to our fancy; and one of the chicf reasons for placing it low in our estimation is, that it has no long and deep reaches of water. It is too streamy. The declivity of its bed is too great from Loch St. Mary, out of which it flows. No river can lay claim to first-rate fishing qualifications that does not abound in long stretches of still and deep water. These are the natural places of shelter and protection for fish, and especially for large ones. These still and tranquil pools are the nurseries-the preserves-the batteaux-so to speak, that supply 
the streams. The still sheets of water are never without a large portion of trout, whatever may be their condition-whether turbid or clear-shallow or flooded. Now, in angling the Yarrow, we have sundry times noticed, that there is not one single piece of still water that trout would take shelter in for any length of time; all is tumbling, broken, shapeless streams. For, to an angler's eye, it is requisite that a stream ever should have a certain shape-a contour-a physiognomy-a character-to solicit his attention and favour. Every disciple of the rod carries about with him an ideal figure of a perfect stream, where, in all rivers-under every parallel of latitude and longitude-he is morally certain to find the object of which he is in quest. This beau ideal of watery conformations is not a variable or uncertain thing; it has in every one's eye the same general outline and expression. We know that what is at this moment prefigured to our imaginations as the height of perfection, is the same as that which occupies the mind of every other angler in the kingdom, who is entitled to the appellation. A fine fishing stream has all the standard elements of permanent beauty that appertain to the beautiful in every branch of art or seience whatever.

But we must take the Yarrow as we find it, and, with all its drawbacks, it is an interesting stream to throw a line in. The distance from its junction with the Ettrick to St. Mary's Loch is about fifteen miles, and the public road runs close to its banks for the entire route. They are generally lofty, and the 


\section{7}

mind is kept continually upon the stretch by the constant succession of delightful landscapes which burst upon the eye from the numerous windings of the river. When the tourist arrives at Douglas burn, he may readily obtain a few fine trout out of it, by means of worm, should he feel so disposed. This small rivulet is a favourite haunt of the salmon and salmon-trout in spawning time, and many hundreds of them fall a prey to the spears and leisters of the poachers at this season of the yeiar.

When the angler arrives at the vicinity of Altrive, formerly the residence of the late James Hogg, the poet, he must consider himself on classic ground. Whether the fish be taking well or ill, he must lay down his rod, look around him, and think of bygone genius, and the mutability of human affairs. Here, upon these very identical river banks, and in these very streams before us, some of the most highly gifted of men were wont to relax the severity of their intellectual studies by the rational hilarity and enjoyments of the rod. Should the tourist's personal experience, like our own, carry him back for five-andthirty years, and should he have been so fortunate as to have ever thrown a fly, for a few hours, with Sir Walter Scott, Hogg, John Wilson, Sir William Chantrey, and Sir Humphrey Davy, how serious will be the train of his thoughts, and what a tender melancholy will insensibly steal over his spirit! These most devoted and enthusiastic anglers, who have filled the world with their fame, have all, alas! save one, quitted the stage of life, and he, it is much 
to be feared, will never again throw a line on his favourite Yarrow. In the little parlour of the Inn by the roadside, the Gordon Arms, in this locality, many a most delightful hour has been spent by these eminent men in recounting afresh their piscatory adventures on the varied waters of the neighbourhood. It will be long before we see their like again.

It is delicious to ascend the valley of the Yarrow in the month of June, when nature appears in her loveliest attire. The woods by the skirts of the mountains send forth the sweetest music. The blackbird and the thrush pipe their richest notes on " the green-wood tree;" and the gentle cooing of the wood-pigeon falls with interesting softness from the surrounding groves. Here, too, we have the joyous lark, pouring a flood of melody in the solitary wilderness. The wild bees, likewise, hum among the honeyed blossoms; and the scented wind, breathing over the fragrant heath, plays with the rustling foliage. Nor do all these fill up the interesting materials of the landscape. We have the soothing murmurings of the river as it falls over its rugged bed; the sheep grazing peacefully by the mountain side; while on some distant part of its breast the shepherd may be seen, wrapped in his plaid, with his sportive dog at his feet, winding his way up the deep ascent.

When the angler arrives at St. Mary's Loch, the general scenery impresses the mind with feelings of loneliness and solitude. This sheet of water is bean- 


\section{9}

tifully described in the second canto of Sir Walter Scott's "Marmion."

"Lone St. Mary's silent lake. .Nor fen nor sedge

Pollute the pure lake's crystal edge. Abrupt and sheer the mountains sink At once upon the level brink; And just a trace of silver sand Marks where the waters meet the land, For in the mirror bright and blue Each hill's huge outline you may viow, Shaggy with heath but lonely bare; Nor tree, nor bush, nor brake is there, Save where of land yon slender line Bears 'thwart the lake the scattered pine. Yet even this nakedness has power, And aids the feelings of the hour; Nor thicket, dell, nor copse you spy, Where living thing concealed might lie. There's nothing left to fancy's guess : You see that all is loneliness. And silence aids : though the steep hills Send to the lake a thousand rills, In summer-tide so soft they weep The sound but lulls the ear asleep ; Your horse's hoof-tread sounds too rude, So stilly is the solitude."

This loch is about three miles in length, and, in some places, nearly a mile in breadth. The upper loch which joins it is called the Loch of the Lowes. It is about a mile in length, and is joined to St. Mary's by a narrow stream of a few feet in width. Both waters are well stocked with good-sized trout. Bull trout have occasionally been caught of great 
weight. One in particular was killed by an English gentleman, in 1846, which weighed nineteen pounds six ounces. There are also pike, eels, and perch, in considerable quantities.

The Meggat, the main feeder of the loch, is a most fruitful stream for trout. It was in this water that Hogg, in some of his writings, tells us, that he once took out of it nearly a cart load of fine trout. When it has been long dry weather, this stream becomes exceedingly small, and will scarcely bear fly fishing; but to take it after a few hours' rain, or when it has subsided into what is called half flood, then is the time to fill a basket. The fish are generally of very fair size for such a water. Some of two pounds weight have occasionally been taken, even in the higher sections of the stream.

The Chapelthorpe and Corse-cleugh streams, that enter the Lowes Loch, are likewise full of trout. To be successful in these small but prolific waters, attention must be paid to their state as to fulness, for, when very small in volume, it is of little use the angler troubling himself with them, except it be for the wildness and grandeur of the scenery in their respective runs.

I have seen almost all kinds of flies used in this district, and with a fair share of success ; but I have generally found that the Yarrow requires good-sized winged flies, and a lightish colour is commonly preferred to any other. There is here, however, no great nicety required; such is my own impression, at least, from what I have myself seen and heard. 


\section{1}

The angler should not visit St. Mary's without calling at the cottage of Mrs. Richardson, known under the cognomen of Tiby Shiels, situated at the junction of the two lochs. Good accommodations can be had; and though the house is small, and its embellishments of rather primitive cast, yet he must not be peevish or fretful, seeing that she can furnish him with a long list of Dukes, and Earls, and Lords, and Baronets, and Savans, who, in their piscatory excursions, have from time to time made themselves happy and cozy under her humble roof.

After leaving St. Mary's Loch and its neighbouring streams, the angler cannot make a more interesting journey than to pass, on the main road which leads to Moffat, to the point where Loch Skene flows over the mountain edge, and forms the wellknown cascade, called the Grey Mare's Tail, and which constitutes the commencement of Moffat water. The walk through the defile of mountains is singularly grand and impressive; and an effort should be made, at the proper locality in the route, to pay a visit to Loch Skene, where fine trout are to be caught, but not in any great numbers.

After the angler is satisfied with this sheet of water, he may then pass off the Moffat road, at the left hand side, and endeavour to make his way through a very rugged and wild district, towards the sources of the Ettrick. This is one of the most romantic angling tours which can be taken in Scotland, inasmuch as it is singularly calculated to impress the mind with a deep sense of loneliness, 
coupled with ideas of wild sublimity and power. A man holds here a somewhat strange communion with himself; he feels an overwhelming sense of strange joy. His own voice and his own movements seem odd and grotesque. He can scarcely for the moment realise that there are such things in existence as great cities, full of people-splendid palaces -crowded streets - and the everlasting din of coaches and vehicles of all sorts, heard for miles, and which falls upon our ear like the distant noise of the ceaseless ocean. All these things seem like a dream to an angler in the Ettrick forest. All things around and about him are so primeval, solitary, and rudely beautiful, that he can scarcely entertain anything like a correct conception of his own position in the world around him. Talk of fish! What are fish to the vivid trains of strange thoughts that rush through the mind in this region of barren and rugged moorland; and which give to the hopes and fears and emotions of the human soul such a singular phantasmagoric representation! It is not the laden basket of fine trout, but the singular state our feelings are placed in, in traversing these desolate tracts of country, that makes a journey through them ever deeply engraved on the tablet of the memory.

As a fishing river, it is impossible to say too much for the Ettrick; every part of it is well filled with trout, with a sprinkling of salmon. It is full thirty miles in extent from its source till it arrives at Selkirk. It has likewise several feeders of some extent, and possessing good fishing waters, especially for 


\section{3}

worm, after a flood. The Timah and the Rankleburn are the chief of these. Whitlings have been caught in the Ettrick in the latter part of the year.

In fishing down the Ettrick, should the tourist feel inclined, he may throw a line into several lakes in the high grounds situated between the Rankle-burn and a stream called the Ale. These small lakes have fine trout, of good average size; and, when the weather is favourable, afford a fair portion of sport. The chief of these waters are Clear-burn, the Shaws loch, and Alemoor. We have seen four dozen of fine rich trout taken out of the last sheet of water, with a brown-winged fly, in less than three hours. We have heard anglers, who have often fished in these lochs, say, that they were always more successful when the wind blew from the east than from any other quarter.

Having now completed the tour of the Yarrow and Ettrick, and arrived at the point of the Tweed from which we set out, we must descend further down this prince of rivers, and give a brief notice of the several sections of it, which require, and are worthy of, particular remark.

The parts of the Tweed below Innerleithen are considered those which form the starting points of good salmon angling. This fish is not found in great abundance higher up in the river, but confines his excursions to those deep and broad stretches of water which afford him shelter, and which we more frequently meet with as the river approaches the sea. The rod-fisher will find that his sport for this noble 
fish is in an inverse ratio to his distance from the mouth of the river; and this rule likewise regulates the market value of all the salmon stations upon its banks.

And here it may be requisite to remark, for the especial guidance of English anglers, who often come to the Tweed entirely ignorant of the rules and privileges connected with their favourite amusement in this part of the kingdom, that there is no substantial restriction put upon rod-angling for trout in any part of the Tweed; but for salmon, and salmon-trout, the same liberty does not exist. The fisheries for the latter fish are, collectively, of considerable value; are regulated by Act of Parliament, and belong to various individuals, some of whom keep them in their own hands, and some rent them to others. The value of these different fishing sections of water depends upon their nature, extent, and distance from the mouth of the river. In 1851, a station at Spital, opposite Berwick, of two hundred yards in extent, yielded a rental of $£ 800$ per annum, while there were many places of five times the extent, between Berwick and Innerleithen, that scarcely brought more than a five-pound note per annum. But the river is thus parcelled out into separate lots, whatever their value, and become subject to the jurisdiction and rules of private property. Many sections of the stream are rented by professional fishermen, who keep a boat, nets, \&c., for the taking of the fish within their respective limits. These men make a trade of accommodating private 
gentlemen with their boats, at the general rate of ten shillings a-day, with refreshments; and this arrangement affords facilities for strangers to indulge in this mode of angling, who would otherwise be cut off from its enjoyment. These boatmen are commonly very skilful anglers, and excellent guides to the haunts of the salmon. To gentlemen who are anxious to try their skill in this highest branch of the "gentle craft," we would recommend them to place themselves under one of these boatmen, who will initiate them, in a short time, into all the mysteries of the art of angling in the Tweed.

What is connected, in the way of legal right and privilege, with the salmon fisheries on this river, apply, in substance, to all the salmon rivers in Scotland.

The waters about Abbotsford, and below it, to the mouth of the Gala, are excellent fishing spots, both for salmon and trout. The Gala itself is now but an indifferent stream for the rod. In hot summers it is often quite dry for some distance from Galashiels; and the manufactures now carried on in this town have gradually rendered the fishing of this feeder scareely worth notice. Higher up in the Gala a few trout are to be had in certain states of the water. The Tweed, from Galashiels to Melrose, presents many stretches of water of great beauty, and which abound with fish at all seasons of the year.

The famous Abbey is only a short step from the river, and its ruins are well entitled to a visit from 


\section{6}

the angler. It was founded about the twelfth century. It unites the minute beauties of its peculiar architecture with the lofty and solemn grandeur for which it is remarkable, more completely than any other monastic ruins in the British Empire. Those unequalled models of delicate workmanship which Sir Walter Scott has so well described, and which particularly display themselves in the upper part of the building, excite the surprise and admiration of all artists.

The stream called the Leader enters the Tweed a little below Melrose, and is well supplied with trout, and will richly afford a day's angling when its waters are in fair order. The Rutherford water is the next feeder of the main river, and is esteemed as a first-rate water. The trout in it are larger, upon an average, than those in any other tributary of the Tweed. It is chiefly to the Rutherford stream that the members of the Tiviotdale Fishing Club resort when contesting for the annual prizes.

The Tweed, from Melrose down to Kelso, is one succession of admirable fishing waters, both for salmon and trout. There is scarcely one locality better than another; they are all equally good. They are frequented every year by the first anglers in the kingdom; and it is in this neighbourhood that they achieve the greater part of their piscatory triumphs.

Having arrived at Kelso, which is a first-rate angling station, we shall here take breath, and propose another tour to the great tributary or branch of the Tweed, namely, the Tiviot, and all its chief 


\section{7}

feeders. This is well entitled to the angler's attention; and we shall attempt to be his guide, commencing at the head of the water, or at that part of its main tributaries which join the English border. But we shall make a few prefatory remarks ere we formally commence our proposed ramble.

The Tweed is very beautiful in the neighbourhood of Kelso. In looking up from the bridge, the scene is very imposing. We see the junction of the two rivers-the ruins of Roxburgh Castle; in the foreground, the Palace of Fleurs, with its sloping and close-shorn lawn, and its drooping trees touching the surface of the waters. On the South side of the river we recognise the mansion of Springwood Park, with the light and handsome bridge over the Tiviot. On the North side is the town, extending along the banks of the river, with Ednaur House, and the lofty ruins of the Abbey, in the distance.

The Tiviot runs through nearly the whole extent of Roxburghshire, conferring the name of Tiviotdale on that portion of it through which it passes. This great arm of the Tweed rises out of the mountain range on the south-west border of the kingdom, and flows a direct north-east course past Hawick, Denholm, to Eckford, and then joins the Tweed a little above Kelso. It runs a course of full forty miles. Its tributary streams are numerous, and are all delightful angling waters, where the sportsman confines his ambition to small trout. The principal of these are the Allan, the Slitrig, the Jed, and the Kail, from the Northumberland border; and 
the Borthwick, and Ale, Selkirkshire. The whole course of the Tiviot is exceedingly beautiful. The valley through which it passes is very fertile, and the banks of the stream are often abrupt, lofty, and picturesque, and in many places studded with gentlemen's seats. The part of the route of the river above the town of Hawick is more pastoral than agricultural. It is a good deal fished in the neighbourhood of Hawick by the manufacturing population of the town. It is advisable to commence a short distance from it. In taking the general tour of the river, the angler will pass through the chief vale of Rule, and the principal mountain ranges of what is denominated Tiviotdale-the Dunian and Ruberslaw. In this interesting ramble we perceive both sides of the river studded with interesting cottages and noble mansions; the most distinguished of the latter is Minto House, the seat of the Earl of Minto. The scenery in the vicinity is exceedingly picturesque and beautiful, particularly from a spot called Barnhill's Bed, which is said to have been the hiding-place of a famous robber of that name, to which circumstance and allusion is made in the following lines of the great Scottish poet :-

"On Minto's crags the moonbeams glint, Where Barnhill hewed his bed of flint, Who flung his outlawed limbs to rest, Where falcons hang their giddy nest. For many a league his prey could spy- 
Cliffs doubling on their echoes borne,

The terrors of the robber's horn;

Cliffs, which for many a later year

The warbling Doric reed shall bear,

When some sad swain shall teach the grove

Ambition is no cure for love."

In the higher departments of the Tiviot, it is difficult for the mind to fix upon any particular spot of its banks more interesting and beautiful than others. There is quite a constellation of fine scenes. Isolated hills and mountains present themselves in defile, and project one behind another like sidescenes in a theatre. They are often intersected by small valleys and strips of land, divided, in some cases, by a small rivulet, which reflects upon its limpid waters the beauty of the trees and bushes by which its banks are adorned. Again we see other hills, which exhibit a mixture of the gloomy and the gay; while those which appear at the back of the scene are veiled with magical effect in the transparent mist of the horizon. On the one bank we see verdant meadows rise with gentle slope to a distant prospect, formed and bounded by small chains of abrupt mountains; on the other we see jutting promontories, and bluff headlands, studded with clumps of dwarfish trees or shrubs, which give a most pleasing effect to the general landscape. It would be difficult to find rural pictures in which the pleasing and the romantic predominate with such a delightful alternation, and such perfect harmony.

Leaving Carlisle, or some of the neighbouring 


\section{0}

parts of the country on the English border, we cross the moors, and arrive at the sources of the Tiviot. The Lymy-Cleugh, and Frostly burns are two of its first feeders. These abound with small, but good trout, and are sometimes taken with worm, in the summer months, after rain, in great numbers. After the main river is increased by these rivulets, it becomes a fair fishing stream, and yields capital sport to the fly-fisher. The streams are commonly compact, full, and rippling, and afford places of shelter for fish of some size. Passing down the stream, we come to where the Allan and Borthwick waters join it. Both these tributaries abound with plenty of trout, of fair average size, and may be caught readily by the worm in summer weather, when not too low and clear. Their respective banks are interesting to the tourist, and many beautiful views present themselves, fitted to captivate the eye of an artist. Near to Goldielands, where the Borthwick joins the Tiviot, stands the interesting ancient border fortress, called Hardin Castle. In the front of this place there is a dark and precipitous dell, clothed on both sides with fine timber; and in the recesses of which the Scottish freebooters of former times were wont to assemble for the division of their lawless spoil. This is alluded to by Sir Walter Scott, in his "Lay of the Last Minstrel."

"Wide lay his lands round Oakwood tower, And wide round haunted Castle Ower; High over Borthwick's mountain flood, His wood-embosomed mansion stood. 
In the dark glen so deep below

The herds of plundered England low."

When the tourist arrives at Hawick, a manufacturing town of considerable extent, he will fall in with the Slitrig, a feeder of the Tiviot. It is only, however, in certain states of the water that this stream is entitled to much notice. Its trout are good, and some even of considerable size have occasionally been taken out of it; but when an angler's time is limited, he must not trifle it away in doubtful and fitful streams. The main river, both for some distance above and below the town, is much fished by the manufacturing population; but, after a good day's rain, I have seen capital sport obtained even in these much frequented localities. For some miles below Hawick the river is beautifully adapted for fly-fishing; and the streams are singularly enchanting to the angler's eye, in point of conformation, and rippling expression.

The Rule enters Tiviot nearly opposite Minto hills. Fine trout are to be had in it, and its banks are pleasing and diversified. The Ale joins the main stream about two miles below the entrance of the Rule. The Ale springs out of the high grounds of Selkirkshire, and has a considerable run-about eighteen or twenty miles. It is a good fishing tributary, and yields trout of fair size and excellent quality.

The angler will find the banks of the Jed, in the neighbourhood of Jedburgh, very picturesque and interesting. The walk through the grove which 
adorns the left bank, near the town, is a really delightful one. The Abbey, a place of great antiquity, is best seen from the banks of the river. The angling in the Jed is good, particularly after a summer's fresh, when the minnow and. worm will be found to do great execution. A fly-fisher must here practice the art of chucking his line underneath the trees and brushwood.

A little below the entrance of the Jed into the Tiviot, we find the Oxnam water. It is not of any great extent; but the main river about this locality, and for some distance down, is exceedingly favourable for the general angler. These places abound with admirable stretches of water.

The Kale tributary is a great favourite with all the anglers about Kelso and its vicinity, and deservedly so. It is full of fine trout; and when they are in the humour-and they are by no means sulky or capricious-they greedily seize everything in the shape of a fly presented to them. Nay, when all shape seemed to have gone-when wings and body were torn to tatters-we have seen them rise at the bare hook as eagerly as at the most highly finished fly that ever came out of a London tackle-maker's shop. The Kale trout are, in fact, the most ravenous and unscrupulous feeders we ever saw.

Finding ourselves again at Kelso, there is a fine succession of streams and stretches of still water, for many miles below it. These have various names bestowed upon them by anglers of the neighbourhood, but they are of no importance to the general 


\section{3}

piscatory tourist. Some of these spots, bearing names, are great favourites with some anglers, while by others they are but lightly esteemed. But the real truth is, that they are all excellent-excellent in the highest sense of the word. They are not to be equalled by any similar extent of water in the kingdom. From Kelso to the mouth of the Eden, a distance of three miles, there is a succession of the finest streams and pools of water that an angler's eye can behold.

He should, if possible, make a point of throwing a line into this small but interesting feeder of the Tweed. The most suitable spot for a short excursion to the Eden is at Ednam, distant about two miles from the main river, and famous for being the birth-place of the poet Thomson, the author of "The Seasons," to whose memory a column has been recently erectéd. The angler of literary taste cannot but feel a great degree of pleasure at visiting a spot hallowed by the memory of such a brilliant genius. The poet left this village in childhood, but he was ever afterwards remarkably attached to the banks of the Eden; and it was probably from his early associations with this stream that he penned his well-known lines on the art of angling:

"When, with his lively ray, the potent sun Has pierc'd the streams, and rous'd the finny race, Then, issuing cheerful to thy sport repair :

Chief should the western breezes curling play, And light o'er æther bear the shadowy clouds. High to their fount, this day, amid the hills 


\section{4}

And woodlands warbling round, trace up the brooks; The next pursue their rocky-channel'd maze Down to the river, in whose ample wave Their little Naiads love to sport at large. Just in the dubious point, where with the pool Is mix'd the trembling stream, or where it boils Around the stone, or from the hollow'd bank Reverted plays in undulating flow, There throw, nice judging, the delusive fly ; And, as you lead it round in artful curve, With eye attentive mark the springing game. Strait as above the surface of the flood They wanton rise, or, urg'd by hunger, leap, Then fix, with gentle twitch, the barbed hook; Some lightly tossing to the grassy bank, And to the shelving shore slow dragging some With various hand proportion'd to their force. If yet too young, and easily deceiv'd, A worthless prey scarce bends your pliant rod. Him, piteous of his youth, and the short space He has enjoy'd the vital light of heaven, Soft disengage, and back into the stream The speekl'd captive throw; but, should you lure From his dark haunt, beneath the tangled roots Of pendant trees, the monarch of the brook, Behoves you then to ply your finest art. Long time he, following cautious, scans the fly, And oft attempts to seize it, but as oft The dimpled water speaks his jealous fear. At last, while haply o'er the shaded sun Passes a cloud, he desperate takes the death With sullen plunge: at once he darts along, Deep struck, and runs out all the lengthen'd line, Then seeks the farthest ooze, the sheltering weed, The eavern'd bank, his old secure abode, And flies aloft, and flounces round the pool, 


\section{5}

Indignant of the guile. With yielding hand,

That feels him still, yet to his furious course

Gives way, you, now retiring, following now,

Across the stream, exhaust his idle rage,

Till floating broad upon his breathless side,

And to his fate abandon'd, to the shore

You gaily drag your unresisting prize."

The Eden rises near to Mellerstain Mill, and has a range of about ten miles. Its banks are covered in many localities with trees and brushwood, and, therefore, a short rod and line are required. It contains no great volume of water, for, even at its entrance to the Tweed, it may, in dry weather, be crossed by a good leap. The trout are fine and rich, and of fair size. The stretches of still water in it are full of fish. It is said that the salmon never ascend its waters, but that the salmon-trout do very freely. The Leet water, which joins the Tweed at Coldstream, abounds with fine large trout, but they are only to be taken when the water is in a certain state of fullness, and with the worm or minnow. A good part of its waters are preserved.

The Tweed, from Coldstream, a good station for the angler, down to the Whitadder, is delightful fishing water, abounding with both salmon and trout. This feeder is an important one to the fishers on the Eastern coast, and is much frequented by sportsmen from many of the towns in the North of England. The Whitadder enters the Tweed about six miles from Berwick-upon-Tweed, and on its northern side. It is a noble stream, and fine salmon and trout are 


\section{6}

taken in it, at all times of the year. The river has a run of full twenty-five miles from its higher feeders, near Blackerstone, till its junction with the main water. The fish are, however, but of poor quality, and run rather small. The Blackadder joins it about ten miles from its mouth, and about two miles from the village of Whitsome. The trout of the Blackadder are quite different from those of the Whitadder. The former are rich in quality, and of large size; they are not, however, so numerous. Some portions of the Blackadder are preserved.

There are some spots of singular beauty on the banks of the Whitadder. I have often ascended some of the more elevated of the hills which bound its course, above the village of Linton, and have been struck with the picturesque grandeur of the views. You see the river winding its way, like a crystal thread, amidst undulating hills and valleys, forests, meadows, country-houses, and church steeples. Sometimes you obtain a glimpse of the Blackadder skirting along a rich and comparatively level track, and pouring its waters into the larger stream. The eye dwells upon the varied prospect with enchantment. As the Whitadder ascends further among the Lammermoor hills, it becomes narrower, and is frequently confined between two deep rocks, which force the waters into rushing streams, which again, after flowing short distances, form deep and wide pools, full to the brim of trout and salmontrout.

If we have angled the Tweed and its tributaries 


\section{7}

with care, and in the genial and loving spirit of the true angler, we shall experience something like regret on leaving its banks. It is a noble and heartstirring stream; and it must be dear to the memory of all who, with rod in hand, have sauntered by its placid waters. In the language of the poet, let us bid it farewell :-

"Sportive young river, we've rambled together Over the mountain-moors, purpled with heather; On, where the foxglove and bracken wave over The blackcock and curlew, the pewit and plover; And down the rough rocks with a shout of delight, Where the wild elfin birches are dancing in white : And onwards again with a sparkle and splash To the dark, dusky woods of oak, alder, and ash; And down deeper still to the green sunny valley, With frolic and laughter, with song and with sally.

"Beautiful river! full many a day In that green happy valley we've sauntered away, Watching the flight of the light cloudy shadows, Listing the low of the kine in the meadows, The chirp of the grasshopper, hum of the bee, And sweet loving song of the bird on the tree; In a world of our own, without sorrow or sin, All peaceful around ns, all peaceful within; While gay pleasant fancies, profuse as the flowers, And musings of calm meditations were ours."

Now, leaving the Tweed, and turning our steps towards the north, along the sea from Berwick, the first stream we meet with is the Eye. It has but a short run of twelve or fourteen miles. Its waters are preserved from Ayton bridge down to the paper 
mills, a distance of about two miles and-a-half. The river is quite free from Ayton to its highest sources; and after a summer fresh, the streams in this direction will yield a fair portion of sport. No salmon or salmon-trout are found higher up than the papermills just mentioned, on account of a wier placed there, which effectually obstructs the fish from ascending higher up the stream. The trout of the Eye are rich, and of average size. There are here and there long stretches of deep water, which are places of shelter for trout, and in which there is commonly good fishing when there is a curl on them. Red-coloured palmer flies are killing in the summer months, but winged ones suit best in the early portions of the spring season. There is often good sport in that section of the river, from the papermill below Ayton House and the sea, during dry weather and the prevalence of easterly winds. There are sometimes good baskets of trout taken here, especially out of the portions of deep and still water in this direction. The Eye is a good stream for worm fishing in fine weather, as its banks are well covered with brushwood.

Should the angler keep by the coast towards Edinburgh, he will enter Haddingtonshire. This is not a first-rate locality for angling, but as it has now the facility of a railway communication from the English metropolis, its streams may become more frequented by anglers than they have hitherto been.

The principal river is the Tyne, which springs out 
of Mid-Lothian, a few miles west from the county. In its course it passes the town of Haddington, and thence flows through the remainder of the Midland district, and falls into the sea three miles west of Tenningham House. There are very large trout in it. Several have been caught weighing six and eight pounds. There are also a good quantity of salmon, and many eels of great size.

The other principal streams in Haddingtonshire are Coalstone, the Biel, Whitewater, the Fastria and the Peffer. These waters run but a short course to the sea, but they all have a good stock of trout; only they are too small to suit first-rate fly anglers.

The best flies are the palmers, the coachman, and blue duns, in these several minor waters.

The angling in Mid-Lothian is of little moment. The principal streams are the Almond, the Leith, the Forth, and the Esk. The scenery in some parts of the last river is beautiful in the extreme, and its streams yield some good trout, but they are preserved in some localities. Salmon are to be found in considerable numbers in all of them.

Trout are very early in season in the lower parts of the Esk. I have often witnessed fine dishes of fish, as red as in the month of May, caught in February or March, a little above Musselburgh. It is one of the curious questions connected with the natural history of the trout, the variation which takes place in their condition in the different streams of Great Britain. 


\section{0}

The following song, by Sir Walter Scott, on the Esk, is worthy of transcription :-

"Sweet are the paths-Oh, passing sweet!

By Esk's fair streams that run, 0'er airy steep, through copsewoods deep, Impervious to the sun.

"There the rapt poet's step may rove, And yield the muse the day;

There beauty, led by timid love,

May shun the tell-tale ray.

"From that fair dome where suit is paid, By blast of bugle free,

To Auchindinny's hazel glade,

And haunted Woodhouselee.

"Who knows not Melville's beechy grove, And Roslin's rocky glen, Dalkeith, which all the virtues love, And classic Hawthornden."

Some of the localities of the Esk are associated with the names of poets of renown. We have Hawthornden rising precipitously from one of its deep glens, anciently the residence of the celebrated poet, William Drummond. It is said that the present house was built by him. In 1619 , Ben Jonson paid him a visit; and the retailers of gossip and anecdote relate that Drummond, when he saw the English poet approaching his residence, ran out to meet him, saying-

"Welcome, welcome, Royal Ben;" to which Jonson promptly responded, "Thank ye, thank ye, Hawthornden." 
As the angler traverses this district from Edinburgh up the Firth, he will pass through a very fertile carse, with a distant view of the Grampians, from Ben-Lomond to Uam Var, and a nearer one of the Ochills, to the ferry opposite Alloa, where there is a crossing over the Firth, just at the point where it changes from a river to an inlet of the sea. It is evident that the country in this neighbourhood is part of a vast coal formation, distinguished from those of England by the absence of the two formations of mountain and magnesian limestone, between which the coal fields of England generally occur, and by the extreme number and magnitude of the beds and veins of secondary trap, which certainly have all the appearance of having been forced up from below by volcanic action. Above Carron and Alloa, on the banks of the Devon, the clay iron ore is particularly abundant, and affords employment to many thousands of industrious and ingenious workmen.

The Devon is an interesting stream to angle, not for the quantity of its trout, but for the interesting and picturesque scenery of its banks. Near to Dollar is the famous Caldron Linn. Here the river is contracted into a narrow chasm, over which men accustomed to the feat, have not unfrequently leaped. It then falls about twenty feet, into a caldron of rock, passes with great violence into a second and a third, and then falls about forty fect into the plain below. Hence we proceed to what is called the Rumbling Bridge, where the river forces its way 
through a chasm of two hundred yards, in one succession of cascades, rapids, and caldrons. For a great part of this length it is at such a depth, and the rocks so nearly meet over it, that it is not possible to see the water, though it announces its presence by a noise that stuns the ear. One of the caldrons, having a noise something like that of a mill, is called the Devil's Mill, because it is at work on Sundays as well as on lawful days. On the lower part of the chasm are two bridges-a new and an old one. A little above this is the Crook of Devon, where the river makes a remarkably acute angle; having previously run in a glen of the Ochills, of the most picturesque beauty, in a direction towards the northeast, it suddenly turns and runs by the base of the same hills, in a south-westerly course, so that, though it runs nearly forty miles, the direct distance from its source to the point where it joins the Forth is little more than five miles. 


\title{
THE CLYDE AND ITS FEEDERS.
}

\author{
"Come to the Banks of Clyde, \\ Where health and joy invite us ; \\ Spring, now, in virgin pride, \\ There waiteth to delight us : \\ Enrobed in green, she smiles serene- \\ Each eye enraptured views her; \\ A brighter dye o'erspreads her sky, \\ And every creature woos her. \\ Come to the Banks of Clyde, \\ Where health and joy invite us; \\ Spring, now, in virgin pride, \\ There waiteth to delight us. \\ "Mark! how the verdant lea, \\ With daisies she is strewing; \\ Hark! now, on every tree, \\ The birds their mates are wooing: \\ Love wakes the notes that swell their throats, \\ Love makes their plumage brighter; \\ Old Father Clyde, in all his pride, \\ Ne'er witness'd bosoms lighter. \\ Mark! how the verdant lea, \\ With daisies she is strewing; \\ Hark ! how, on every tree,
}

The birds their mates are wooing."

ALEX. RODGER.

We come now to sketch out another extensive and interesting angling tour, taking Glasgow as our central point of view. But we would recommend all anglers, who can spare the time and money, should they be in this city or its neighbourhood, to fish the river downwards from its early risings, this being infinitely more pleasing and convenient. The Caledonian Railway will take the rod-fisher above sixty miles along its banks, and place him at once in the midst of splendid angling water. To the tourist from the English border, the Elvanfoot station, on the same railway, must be his starting point. 
The Clyde is the third river in Scotland in point of magnitude. It takes its rise from the summit of the mountain range, traversing the South of Scotland-the Lowthers, 3,150 feet above the level of the sea; the Lead hills; Queensberry hills, 2,259 feet; and the hills connected with Hart-Fell, 2,790 feet. These form a sort of semicircle, out of which the rivulets spring, which, when united, constitute the Clyde. The largest of these is called the Daer, and another, smaller, is termed the Clyde, before their union. Where this takes place is called the Meeting of the Waters, or Water-meetings. The joint streams flow in a northerly direction for several miles.

Supposing the angler makes his way to the sources of the Clyde, he will have to do this through a wild and naked country; and should he be in that section of the county of Dumfriesshire in which Moffatt is situated, a walk over the hills, extending to eight or ten miles, will bring him amidst the several springs of the main river. He will meet with the Croak Burn, Powtrail Water, Elvan Water, Evan Water, and Little Clyde. All these, and other minor rivulets, are comprehended within the range of the chief stream, when it arrives at the village or station of Elvanfoot.

The angling is good nearly the whole of the distance from where the river becomes fishable to this spot; and it gradually improves as the waters increase in breadth and volume. The river presents one continued succession of finely formed and rip- 
pling streams, where there is neither bush, nor tree, nor obstacle of any kind to impede the rod-fisher's movements in the prosecution of his art. The trout are, even in these higher branches of the river, much larger than could be anticipated in such localities. Indeed, there have some been caught of gigantic size; one burn trout of ten, and another of seven pounds, come within the range of our own knowledge, within the last three years, as having been taken out of these comparatively small and limpid streams. It may be here observed, that the trout of the Clyde generally are much larger, and of much richer flavour, than those commonly caught in the Tweed. There are some of the tributaries of the latter river which abound with larger and finer tasted trout than even those of the Clyde; but what are to be had in the main channel of the Tweed are neither so large nor so highly flavoured as those found in all the sections of the Clyde. Both rivers differ considerably in their leading features, and both fish, and the art of fishing, are modified accordingly.

There is a beautiful succession of fishing streams between Elvanfoot and Abington. In the latter village, situated a few hundreds of yards from the banks of the river, there is a good Inn for general accommodation, and where many anglers during the season make their head quarters. The fare is good, and charges moderate; and the landlord is always provided with a couple of good fishing-rods, and a stock of lines and flies, which are at his guests' service in case of need. The Glenooner Water enters 
the Clyde near this spot, and contains a great number of small trout, quantities of which are often taken with worm in the summer months after rain.

Near to Crawford is a magnificent Roman encampment at Gadenica, or Little Clyde. There was here a Celtic town, the remains of which have for ages escaped the researches of the antiquary, but which have been recently discovered. The Damnii, a British tribe, that spread from the shores of the western ocean, and filled the glens and valleys of upper Clydesdale, had here a strong fortress, and a populous town. A stranger now surveying the bleak and dreary locality would never imagine that Roman legions and Celtic clans peopled this wilderness with an active population, where now only a single farm building, or a solitary shepherd's hut, is to be seen.

The waters of the Clyde continue excellent all the distance from Abington to Biggar Bridge. There is a constant alternation of fine streams and long and deep pools. The trout are often found here of considerable size. In traversing this district, the tourist will pass Duneaton Water, which enters the Clyde near a village of the same name. This tributary is itself fed by the Black Burn and Snar Water. There is good worm fishing in all these smaller streams. About a mile before coming to Biggar Bridge, the stream called Culter Water is worthy of notice. It runs among the hills in a most enchanting manner; and its narrow streams and deep gullies are full of small but excellently flavoured trout. There arefew anglers in the neighbourhood but like to have a 
ramble, once in the season at least, up to Culter Water.

When the angler is in this locality, he must pay a visit, if possible, to the top of Tinto, one of the finest hills in this part of Scotland. There is a kind of foot-path to its summit from the village of Symington. It will require about an hour to arrive at the heap of stones placed on its crown; but the pleasure from it, on a fine day, will amply repay the toil of the ascent. We enjoy a most delightful prospect. The valley of cultivated country stretching out to the east and north, cleared of mist, and illumined by the radiance of a declining sun, is a lovely object for the eye to rest upon. The vale of the Clyde, like a rose just expanded, lies at our feet, displaying its woods, its hills, its plains, highly cultivated, and its numerous terraces covered with hamlets and farm-houses. Amidst the most deathlike stillness, we occasionally hear the barkings of the shepherd's dog, the flowing of the waters, and the murmurings of the wind, mingled together, softened by distance, and which, uniting with all that lies before us, express a state of existence, calm, extensive, and diversified. One cannot describe the soothing, consolatory, but infinite and sublime ideas, which overpower the soul at a sight like this, and which fill it with love for the God of nature, and confidence in his works. And if, in the interval of such noises, which succeed each other like waves of the ocean, the song or whistling of a shepherd is heard for a moment, the thoughts of man seem to 
elevate themselves with such intimations of humanity, and to carry his wants and his troubles to heaven, and to implore it to relieve them. How many things does the distant voice of this mountain shepherd make us feel and think of! But such delightful emotions pass away like a beautiful dream, like a fine piece of music, like a striking effect of light, like everything that is good, like everything which affects us strongly, and must, for that reason, endure but for an instant.

What is here said of this delightful prospect from the top of Tinto, may, indeed, be said of twenty other localities in this interesting land of beautiful and splendid scenery. I wish that all the anglers of England could see this diversity of woods, and plains, and meadows, and torrents, and villages, surrounded by mountains, either green to their very summits, or peaked with bold and rugged grandeur. There are some things in nature that one feels somewhat competent to deseribe but such scenes as these make one lament the poverty of language; even the pencil cannot represent that effect of immensity, nor express those confused and delicious sounds, nor make us breathe the pure and bracing air which renders the spirits so lively and buoyant. We must send the reader to the spot, and give up the attempt to paint natural beauties which are inimitable.

There are many excellent stretches of angling water below Symington, and between it and where the Douglas Water falls into the main river. The banks of the river are here quite open, and beautiful 
for fly fishing; and in the deep pools the largest and best fish are to be obtained. The Douglas tributary joins the Clyde about four miles above the falls and should the angler feel disposed to ramble up its streams, he will find a very beautiful and interesting series of views and landscapes. A short distance up, the waters of the rivulet called Paniell Water join it. Good fishing may be had in both streams, with worm, after a summer's rain. The trout of the Douglas are rich, and of fair average size. We have seen six dozen caught here in a couple of hours, chiefly with the fly. The red and black hackles are killing flies in the summer months.

The romantic valley of Douglasdale is full of interest, both to the lover of fine scenery and to the historian. The hills, and woods, and glens about it, are of a most interesting kind; and the country legends connected with the towers and family residences on its banks, are full of the marvellous and exciting.

On the opposite side of the Clyde, the Medwin Water falls into it, in which there is a fair stock of smallish trout. Some parts of the banks of this tributary are very interesting. Those who are fond of lake fishing, will find the Crane Loch, in the parish of Dunsyre, lying in a wild moorland locality. It has both pike and perch of considerable size. Not far from this is the White Loch, containing fish of the same kind. It may here be mentioned, that in all this range of the Clyde we have invariably found the minnow to be a great favourite with the 


\section{0}

anglers who frequent the river regularly. The largest and best fish are eaught in this way.

It is likewise worthy of remark, that this long range of the Clyde, that is, from the entrance of the Douglas Water to the highest springs of the main stream, is much damaged by net-fishing. It is astonishing, as well as lamentable, to hear of such quantities of fine trout taken by this murderous and unmanly method. The angling is also greatly impaired from the practice of fly-fishing with double rods; one person at each side of the river, with a line stretched right across, baited with perhaps forty or fifty artificial flies, suspended from it. This unfair eontrivance has, indeed, been put down in some districts of the river, but it still prevails to a shameful extent in other localities.

All unfair modes of fishing tend to destroy the real pleasure attending the art. This has been the prevailing sentiment among all the disciples of the rod and line in England from the earliest times of her angling literature. More than two centuries ago, in 1646, we have some verses, of a quaint cast certainly, written by Llewellyn, in his "Men Miraeles," in which the writer rails and satyrises the encroachments upon the gentlemanly modes of fishing in his own day, in no very courteous and measured terms :-

"You that fish for dace and roches, Carpes and tenches, bonus noches, Thou was borne betweene two dishes, When the Fryday signe was fishes. 


\section{1}

Angler's yeares are made and spent, All in Ember weekes and Lent.

Breake thy rod about thy noddle, Throw thy worms and flies by the pottle, Kcepe thy corke to stop thy bottle, Make straight thy hooke, be not afeared To shave his beard;

That in case of started stitches, Hooke and line may mend thy breaches.

"He that searches pools and dikes, Halters jackes, and strangles pikes, Let him know, tho' he think he wise is, 'Tis not a sport, but an assizes. Fish to hooke, were the case disputed, Are not tooke, but executed.

Breake thy rod, \&c., \&c.

"You whose pastes fox rivers throat And make Isis pay her groat, That from May to parch October, Scarce a minnow can keep sober; Be your fish in open thrust, And your owne red-paste the crust. Breake thy rod, \&c., \&c.

"Hookes and lines of larger sizes, Souch as the tyrant that troules devises, Fishes nere believe his fable, What he calls a line is a cable; That's a knave of endless rancour, Who for a hooke doth cast an anchor.

Breake thy rod, \&c., \&c.

"But of all men he is the cheater, Who with small fish takes up the greater; He makes carps without all dudgeon, Makes a Jonas of a gudgeon; 
Cruell man that stayes on gravell, Fish that great with fish doth travel. Breake thy rod, \&c., \&c."

We assume that the angling tourist will take a peep at the celebrated Falls as he passes down the river. We shall say a word on the subject, and only a word or two, as these waterfalls are elaborately described in all the host of handbooks and guides of the day.

The two celebrated cataracts are the Corra Linn and Stonebyres. At Corra Linn, the rocks at both sides compress the bed of the river so much, that the waters in some places rush down a chasm of not more than four or five feet wide. At the fall itself, the river dashes over a height of nearly one hundred feet. On the pointed cliff, just opposite to where the water falls over the steep ascent, stands the ruins of a Castle. When the torrent is much swollen, this entire cliff, and likewise the Castle, are sensibly shaken; and this is made manifest by water in a glass being spilled by the concussion of the mighty stream. A mile further up the river is the fall of Stonebyres, still more striking and sublime than that of Corra. The walk between the two is delightful and interesting in the highest degree. The rocks rise on each side to the height of full one hundred feet above the bed of the river, and are well covered with wood. The channel is of solid rock, here and there worn into cavities by the force of the agitated waters. The Clyde is broader here than at Corra, but the scenery is more diversified by the wild and 
turbulent eddies which the foaming billows make, and which impress the imagination with a deep sense of awfulness and grandeur.

Salmon and salmon-trout are found in the Clyde below the falls. The fishing is generally pretty good for some distance below the last fall, and the country improves very much in appearance. The banks of the river become better clothed in timber and brushwood; and the land for some distance from its bed presents an aspect of great fertility, and a consummate skill in husbandry. There are many delightful landscapes which cannot fail to take hold of the fancy of the tourist and man of taste.

The Nathan Water enters the Clyde about six miles below Lanark, and will afford the angler some sport when its waters are in order, after a summer freshet. The stream rises out of the higher grounds on the confines of Dumfriesshire, and it receives several small feeders, in which fine trout are occasionally taken with worm, even in hot and dry weather, when the waters are both clear and shallow.

The Nathan forms a junction with the Logan at Cleuchbrae. The streams of the main water after this run deep and narrow in many localities; and the precipitous sides of the rocks on its banks are richly decorated with the stately oak, the fragrant birch, and the tapering mountain ash.

The Clyde, below the entrance of the Nathan, and as far as the palace of Hamilton, presents many stretches of water of great fishing capabilities. 
There are long deep pools in which large fish may always be found; and even in the clearest weather, and when the river is very low, if there be a good breeze from any quarter of the compass, a basket of fish may be readily taken. As the stream widens, it becomes less manageable unless by wading, a thing we do not by any means recommend to the tourist, except he be well fortified by habit, and a strong constitution.

The tributary called the Avon enters the chief river at Hamilton. It has a circuitous run of about twenty miles, through a somewhat cold and ungenial country. It has several small feeders in its higher localities, in all of which there is an abundance of small trout, which are often taken in profuse abundance of summer rains, and principally by the worm. The entire banks of the Avon are delightfully picturesque and beautiful, and abound with those abrupt and grotesque peeps into dells and groves, in which the pencil of the artist loves to dwell. As a fishing stream, it is not, on the whole, of much value. Its waters generally get so low in the summer months, that little or nothing can be effected with the fly; red worm, in the still pools and shady avenues of the river, being the only bait that can be used with any chance of success.

Passing down the Clyde from Hamilton, where its streams are for some distance strictly preserved, we come to the beautiful neighbourhood of Bothwell Castle, so full of historical recollections of ancient date, and stirring interest. The river is splendidly 


\section{5}

adorned with fine wood, which adds so much real beauty to all running water scenes, but which is often an impediment to the free and unshackled exercise of the fly-rod.

The country in this section of the Clyde is very interesting to Scotchmen especially, on account of the poetical associations connected with it, and likewise as being one of the chief battle-fields where the Covenanters fought and suffered for the sake of religious freedom. There was a great slaughter made of them at Bothwell Bridge, in the early part of the sixteenth century; and there is scarcely a remote dell or sequestered rock, for many miles on each side of the river, that is not hallowed as a traditionary hiding-place of some of these truly heroic and cruelly persecuted men. This locality is likewise considered as the cradle of Scottish poetry and song. "Oh! Bothwell bank, thou bloomest fair," carries with it both the feclings of ontiquity and admiration in the minds of the country-people in the neighbourhood. And a story is told by historians of credit, connected with this popular air, which, though it may appear to ordinary readers as partaking of the marvellous, is, to our minds, perfectly natural, and, we have no doubt, perfectly true. The fact is derived from a work published at Amsterdam, in Holland, in the year 1605. It runs thus:-A Scotch gentleman, travelling through Palestine, recognised a female at a door lulling a child to sleep, to the tune of Bothwell Bank. Under the influence of surprise and delight, he accosted the female. She said she was 


\section{- 56}

a native of Scotland, had wandered thither, married a Turk of rank, but still took especial delight in singing the songs of her native land. She introduced the traveller to her husband, whose influence proved of service to the traveller, who was ever after deeply impressed with the value and important influence which national melodies have over the human heart.

The fisher will find many beautiful streams between Bothwell Castle and the tide-way, at the confines of the City of Glasgow. This section of the water is, however, a good deal fished, at all seasons of the year, both by fair and unfair means. 


\section{PAR'T II.}

\section{SOUTH WESTERN DIVISION,}

Embracing the Counties of

Renfrew, Axr, Dumfries, Kirkcudbright, ANd Wigton.

WE have taken the angler, in the preceding part, over an interesting section of the country, and placed him on the banks of some of the very finest streams that any one can visit. We now come to another piscatory tour, along the South-Western part of Scotland, taking Glasgow as our centre of observation and departure, The angler has a ready and commodious means of transit to many of the rivers in this district, by the South-Western Railway to Carlisle. This skirts along the low and fertile parts of the country in the form of a half-circle, and joins the great trunk of the Caledonian Railway near to Gretna Green.

The various rivers and streams in this direction are not so large, nor so highly celebrated in angling history and exploits, as the Tweed and the Clyde, with their tributary waters, but they are, on the 
whole, very pleasant rod-fishing localities, and calculated to afford the tourist a series of agreeable riverside rambles.

We shall commence our notice of these fishing waters from the English border, for the especial guidance of tourists from the south part of the island, who may make Carlisle the point of their departure. Within a few miles to the north of the city, there are several streams which fall into the Solway Firth, in which good trout fishing is to be obtained. And first, we have the river Esk, which has a long and winding run through the SouthEastern section of Dumfriesshire, and falls into the Solway about four miles from Carlisle. This stream abounds with both salmon and salmon-trout, as well as with the common burn trout. The coach-road to Hawick leads close by the sides of the river as far as the town of Langholm, and this is a very excellent spot to go to at first, in order to angle the river down to the sea. It has a run, however, of full twenty miles above this town, but its waters are small from its rise downwards till they receive an accession from the Black Esk, which enters it at Panlaw Hill. Capital sport may be had in both these higher waters, especially with worm, or, if after a flood, with minnow. The fishers in Langholm and its neighbourhood often obtain large baskets of fine fish during the summer months. The prevailing colours of the flies, when here used, are the light brown winged ones, and the red and black palmers. But, indeed, the trout often take here so 
greedily, that no great nicety in the choiee of flies need be observed.

The Ennis Water joins the Esk at Langholm, and has a run of full ten miles. It is full of small trout, but not to be fished with fly. The Tarras is another feeder, which enters the main river a few miles below, and it partakes of much of the same character as the Ennis.

'The Liddal, which springs from the English border, and which flows a few miles within the boundary line of Scotland, is a good fishing stream, when its waters are not too fine and low. It has long been celebrated from the beautiful lines ascribed to it, and other neighbouring rivers, by Dr. Armstrong, in his poem, "On the Means of Preserving Health," who, in his younger days, was a keen angler on the banks of the Liddal.

"But if the breathless chase o'er hill and dale

Exceed your strength, a sport of less fatigue,

Not less delightful, the prolific stream

Affords. The crystal rivulet that o'er

A stony channel rolls its rapid surge,

Swarms with the silver fry. Such through the bounds

Of pastoral Stafford, runs the brawling Trent;

Such Eden, sprung from Cambrian mountains ; such

The Esk, o'erhung with woods; and such the stream,

On whose arcadian banks I first drew air.

Liddal till now, except in Doric lays,

Tuned to her murmurs by her love-sick swains,

Unknown to song: though not a purer stream

Through wood more flowery, more romantic groves,

Rolls towards the western main. Hail sacred flood!

May still thy hospitable swains be blest 


\section{0}

In rural innocence; thy mountains still

Teem with the fleecy race; thy tuneful woods

For ever flourish; and thy vales look gay

With planted meadows, and the golden grain.

Oft with thy blooming sons, when life was new,

Sportive and petulant, and charmed with toys,

In thy transparent eddies have I laved;

Oft traced with patient steps the fairy banks

With the well-imitated fly to hook

The eager trout, and with the slender line

And jielding rod, solicit to the shore,

The struggling panting prey; while vernal clouds

And tepid gales obscured the ruffled pool,

And from the deeps call'd forth the wanton swarm.

There are few rivers of the same limited range, whose banks are more picturesque, and streams more agreeable to fish, than those of the Esk. Its entire bed, except near or about the tide-way, is comparatively narrow, which circumstance gives a fulness and depth to its waters, favourable, even in dry and parched seasons, to the rod-fisher's sport. The winding and circuitous route of the river adds, likewise, to its interest; as we have ever and anon presented to us some fine view, or agreeable combination of brushwood, and running water-things which have a remarkably plesant effect upon those who have an eye for beauties of rural scenery.

The next stream, towards the north, is the Sark, which runs into the Firth, but has no great range. In particular states of its waters, in the summer months, a good dish of smallish trout may be readily obtained. The Kirtle Water, which enters the same estuary a little lower down towards the sea, is 
a longer and more fishable stream. I have found the palmer flies, both red and black, very successful here in the summer season after the rain. The Kirtle trout run rather small, and not of first-rate quality.

It may be observed here, that the Caledonian Railway runs through the South-Eastern portion of Dumfriesshire to five or six miles north of Moffat, and nearly parallel with the river Annan and some of its tributaries. This renders the rivers in this section of Scotland casily and cheaply accessible. The Annan rises out of the same range of hills from which the Tweed and the Clyde derive their first feeders, and it has a run, including its numerous windings, of about forty miles. It flows by the small town of Moffat, now yearly visited by numerous persons from all parts of the United Kingdom for the medical springs in its immediate vicinity. But the Annan is not worth much as an angling stream till it comes to what is called the Meeting of the Waters, that is, the junction of the Moffat Water and the Avon with the main river, about two miles below Moffat. The higher portions of it are exceedingly beautiful in the way of mountain scenery, but the fish are both scaree and small in these localities. The angler is, however, earnestly solicited by the poet to ascend these higher waters, and to visit the Devil's Beef Tub.

"Away to the hollow, among Moffat hills

Nam'd the Devil's Beef Tub, wherein three little rills, The Tweed, Clyde, and Annan, pure rippling arise 'Mong bold mountain tops, that brave cold growling skies. 


\section{2}

Here nature-wild nature-reigns glorious and free,

Then come here in summer, and angle with me.

"It is life to the soul to climb these steep knolls,

To watch the gay trout, as he sports in the pools;

The scene is so rich, and the landscapes so fair,

That the mind feels content to dwell always there,

To sean the bright shadows on the grey mountain's brow,

Is a pleasure that dullness itself must allow.

"There's strength in the mountain, and health in the vale,

There's glow in the zephyr, and glee in the gale;

A buoyant hilarity rests on the mind,

And lightness and joy at each step are combin'd.

So come, anglers, come, rare sports here invite you,

Sure pleasures so pure ean't fail to delight you."

Moffat is the best starting point to fish the Annan and its chief feeders. The Annan is not a good trout stream. It has a run of several miles, and its streams look very imposing to the eye, but there are very few trout in them. What there are, however, are often tolerably large. The Moffat Water comes from another direction. It flows down the narrow valley between St. Mary's Loch and Moffat, and has a connexion with Loch Skene by means of the Grey Mare's Tail burn. There is good trouting in the Moffatt Water, but I have never seen very large ones taken out of it. It is a pleasant stream to angle with a single-handed rod; and its banks and windings among the high hills have a solemnising and contemplative effect upon the mind.

If the angler ascends the stream till he comes to the rivulet that leads up to the Grey Mare's Tail, he will be much interested. This glen forms an 
immense cliff between two high mountainous ridges, running from east to west. The descent from either side is stcep and rugged in the extreme. The valley is very narrow through which the Moffat makes its way, with many abrupt windings. The river is stretched out like a silver thread as we cast an eye down the vale from any of the surrounding hills. For a considerable distance, the vale does not average more than two or three hundred yards in width; and the whole scene often recalls to the mind the vale of Tempe, so graphically described by Ailian. There are here, however, no smoking altars of incense-no thickets overshadowing the sides of the stream, to screen the weary traveller from the rays of the sun-no convivial parties enjoying themselves in sequestered groves-no musical birds warbling among the green branches of the iry-mantled trees, described in the celebrated defile between Ossa and Olympus ; but, notwithstanding all this, the glen is a scene which, for simplicity and grandeur, cannot easily be rivalled, and the tourist who has once passed through it will not soon forget it. Sir Walter Scott thus dashes off some of its leading features :-

"Through the rude barriers of the lake, A way the hurrying waters break, Faster and whiter, dash and curl, Till down the dark abyss they hurl; Then issuing forth, one foaming wave, And wheeling round the giant's grave, White as the snowy charger's tail, Drive down the pass of Moffat dale." 


\section{4}

Good fishing in the Annan commences about Wamphray, nearly five miles below Moffat. The streams here become broader, deeper, and abound more with places of shelter for good trout and salmon. There is a succession of fine streams and stretches of still water from this village to the neighbourhood of Lockerby. This small town is a good station for a day or two's sport. It has a good inn, at moderate prices: and the river is about a mile and-a-half from it. The scenery in the vicinity is very prepossessing, though flat, and rather of a swampy character. The trout of the Annan are above the average size, and of good quality. Some, indeed, have been caught of very great weight, chiefly by means of the minnow.

Before the river reaches Lockerby, it receives the waters of several tributaries, such as the Wamphray, the Drife, and the Kinnel, in all of which there is good trout fishing at particular seasons of the year, chiefly, however, with worm. In the vicinity of the Kinnel, lie the Lochmaben lochs, which are much frequented by anglers. They are nine in number, and the longest one, ealled Castle Loch, contains fifteen distinct species of fish that may be angled for. There are trout in all these still waters of twelve and fourteen pounds weight, and a good number which run from two to five pounds. There is a club of Dumfries anglers who fish for the vendace, in Castle Loch, yearly, and prizes are awarded to the most successful competitors. Large and somewhat gaudy flies are used; and trolling with a small trout is a very deadly bait, on particular occasions, when 
wind and weather are favourable. There are considerable quantities of bottom fish in these lochs, such as bream, roach, chub, perch, and pike; some of the latter kind of fish having been taken upwards of thirty pounds weight.

The vendace just mentioned is a somewhat singular fish, and is described as a species of fish known nowhere else, and which, from its peculiar delicacy, as an article for the table, is highly prized. It has hitherto defied all attempts at being transported to other waters. "It is a beautiful fish, from four to six inches in length, and of a bright silvery appearance, with a slight tendency to a light blue along the back and sides. Upon the top of the head there is a very distinct shape of a heart, covered with a transparent substance of a brownish colour, resembling a thin lamina of mica slate, through which the brain is visible. Nothing to the naked eye is found in the stomach, though a late inquirer has said that their food consists of incredibly minute eutromostracea. Overlooking the fact that the vendace dies the moment it is touched, or brought to the air, and has hitherto defied transportation, the common people speak of its having been brought by one of the Jameses, from Vendois, in France."

The angling continues good from Lockerby to the town of Annan. The trout are commonly larger the nearer you approach the sea. I have seen almost all kinds of flies used on the Annan, and nearly with equal success; and my impression is, 


\section{6}

that a trout-fisher need not be very fastidious in making a selection from his stock.

The vale of Annan, taken altogether, forms a most interesting part of Scotland. From the rising ground on the east of Totherwold heights, there is a splendid prospect. Beneath lies "Margory of the mossy beds," and the ancient castle of the Bruce, mouldering among the stately trees. On the margin of the glassy lake, whose silvery waves, rippling before the southern breeze, murmur in the ear many tales of feudal times, connected with the grey ruins which still appear in solitary grandeur, the entire valley, stretching from north to south, where it terminates at the base of the frowning mountains between it and the wilds of Tweedsmuir, furnishes a diversity of scenery so enchanting, that few localities in the South of Scotland can equal it. The wilder parts of the country, on either side, are full of covenanting associations.

The stream called the Locher lies between the Annan and the Nith, and contains good sized trout, in tolerable abundance. It has a range of about fifteen miles fair fishable water. In some spots its banks are pleasant and picturesque; and an angler who has time at his command may spend a day here very agreeably.

The Nith is the great river in this section of Scotland. It springs from near New Cumnock, in Ayrshire, where it receives the tributary called Afton Water, which is full of small but good flavoured trout. These can only be had with worm in any 


\section{7}

considerable quantities. The waters of the stream issue from among the dusky mountains in the south. The scenery on their banks is a constant theme of exultation among the inhabitants of the neighbourhood.

The Nith is not, by many anglers, considered a firstrate water for salmon and trout fishing; yet it is well entitled to a visit by any one who has not previously scen the country on and around its banks. A tour along its waters is highly interesting in the summer months. It has a great range, amounting to above a hundred miles, taking all its windings and doublings into account, and presents to the eye an agreeable diversity of landscapes, the majority of which are, however, of the bleak and rugged kind. The mountains of Nithdale are exceedingly interesting. From the tops of their lofty heights an extensive and magnificent view is obtained of the greater part of the west and south of Scotland. On the south we recognise the range of the Galloway hills; on the west, the desolate solitudes of Kyle; on the east, the heathy mountains of Crawford Moor; and on the north, the majestic Tinto, waving afar his misty mantle, and revealing through the opening of its folds the rudy and fiery scars which the angry elements have made on his shaggy and time-worn sides. The dark blue mountain of Crieffil is likewise a conspicuous object in the upper part of Nithdale. It commands an extensive view over the Solway Firth, and a large tract of land lying towards the west. The scenery in the immediate locality of the moun- 


\section{8}

tain is of the richest kind. The hills around are not clad with heather, but covered with deep verdure.

The history of bygone times, and religious associations, impart a lively interest to our rambles in these districts. The solitudes of the upper parts of the river were favourite places of refuge for the Covenanters in the days of persecution and bigotry. The imagination is deeply affected in visiting such localities. One can scarcely conceive retirements more sterile and dreary than those which lie towards the north-west of Sanquhar. From the summit of the loftiest hills we discover nothing but an interminable range of rugged mountains, covered with brown heath. Vast tracts of dark moorland stretch for miles in the distance, and here and there the eye and the heart are relieved by the blue smoke curling from the chimneys of the lonely shepherds' huts and cottages. When we connect the scenes around us with the struggles for religious and civil freedom, made in these dreary solitudes, by a noble-hearted set of men, there is life and interest imparted to every spot and rood of ground we travel over.

Nor is this at all surprising. The fate of these high-minded men touches some of the deepest sympathies of the human soul. They have long passed into another state, and are no more cognizable to human eye; but their memories will prove as enduring as the rocks and glens in which they took refuge. The shadows which fleeted over the mountain's brow, and on which they were wont to gaze; the deep wilderness around them, speaking more 


\section{9}

loudly to the inward man than a thousand tongues, must have greatly heightened their devotions-must have impressed them with a vague sense of infinity - of the littleness of human life-and of the grandeur of a divine existence and eternity.

"At the risk of their lives with their flocks they would meet, In storm and in tempest, in rain and in sleet;

Where the mists in the moor-glens lay darkest-'twas there, In the thick cloud concealed, they assembled for prayer.

"In cities the wells of salvation were sealed,

More brightly to burst in the moor and the field;

And the spirit which fled from the dwellings of men,

Like the manna-cloud rained round the cup in the glen."

In fishing the Nith from its highest feeders down to Sanquhar, we found brown-coloured flies very successful ; but still, even here, no general rules can be laid down on this subject. As an instance of this, while we were one day fishing the stream, and obtaining fair sport with coloured fly, we saw two country lads, one using a black fly, and the other a very light grey one, both appearing as successful as ourselves.

The Crawick Water enters the Nith near to Sanquhar, and having had a run up its banks, we were delighted with them. It is a pastoral stream, which

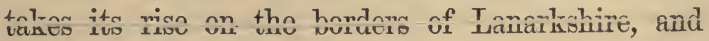
wends its course in a south-western direction until it falls into the Nith at the place just mentioned. The whole range of the Crawick exhibits scenes of surpassing interest and beauty. The mountains by its side, covered with a lively verdure, present the 
appearance of newly mown meadows; while again, some of the hills jut out so abruptly from their base that a person can scarcely walk steadily along the velvet slopes. The trout in the stream are but small, but firm and well tasted. A few dozens are soon taken when the waters are in good trim.

The angler who travels through those mountain passes must beware of the mists which suddenly arise on these heights, and which render travelling both disagreeable, and sometimes dangerous. These mists give little warning of their approach. Sometimes, instead of descending in a body, like a large snowy cloud, spreading itself along the ridges and down the slopes of the mountains, they come edgeways, trailing along, and like a thin white veil, extending from the clouds to the earth. Then it is that the pedestrian must move with care and circumspection.

The Kello Water enters the Nith a little above Sanquhar, and the Minnick below it. They are both good for small trout, but in the summer months are often extremely low, and this renders sport somewhat precarious. Sanquhar itself is a burgh which lays claim to considerable antiquity. The scenery in its neighbourhood is interesting, and in snme snots magnificent. There is a nastrnal sweetness about some of its localities, which deeply rivets the attention of a stranger. The clear and silvery streams, the Minnick and Cramock, present a picture not always to be met with. The town is noted for many daring and bloody scenes perpetrated 
in former days of religious and political contention and faction.

Speaking generally, we may say with justice, that there are few rural scenes, upon a narrow scale, which present a more lovely and agreeable spectacle than those which are to be found in the several localities of these. upper waters of the Nith. In many places the uncultivated moorlands are flanked by hills whose summits rise like lofty colonnades to the clouds, and remind us of the sublime Scriptural expression, "the pillars of heaven." Here and there we see a beautiful mountain, clad in velvet green, and tipped with its warder cairn; while at its base we recognise some little and solitary hamlet, sending up its smoke, and skirted with a few acres of well cultivated land. In the stillness of a summer's evening, when the mind is in a contemplative mood, one surveys such scenes as these with a feeling of enchantment one is loath to dissipate.

The Euchan stream enters the Nith from an opposite side to that of the feeders just mentioned, but still in the locality of Sanquhar. This is a beautiful stream. Its banks are ornamented with wood to their very edges. The bed of the river, for the most part, is composed of blue whinstone, and is worn by the action of the water as smooth as a polished pebble. The stream has a run of only about ten miles.

The angling in the Nith from Sanquhar to where the Enterkin, or Ken Water, enters it, about seven miles below the town, is excellent. Some of the 
finest streams of the main river are to be met with in this locality. Most of the streams are of that precise conformation which gives pleasure to the angler's eye, and assures him of sport.

The Ken is an interesting and pastoral stream, of no great length, and fed by several small rills from the neighbouring mountains, whose bold and majestic head-lands tower to a stupendous height. The angler, when on the Nith, should make a point of ascending the Ken. Few localities in Scotland are more full of interest than those on its banks. There are, indeed, some spots which present such harsh and melancholy aspects as to produce an absolite depression of spirits; but this circumstance rather adds to than detracts from the interest we feel in such rugged wildernesses.

The stream abounds in small fish. We have known six dozen taken out of it, with worm, in three or four hours, after a freshet in July.

The Scar joins the Nith a considerable distance below the Ken, on the opposite side of the main river. The Scar has a range of full twenty-five miles, and is a good stream for rod-fishing. The trout run small, though we once saw a fish of four pounds and-a-half taken out of the stream near its entrance to the Nith. But this was considered a great novelty. There is an immense rock in the valley of the Sear of nearly a thousand feet perpendicular. This is one of those bold features of nature which inspire the beholder with the mingled feelings of delight and awe. A multitude of legends are 


\section{3}

connected with the place, and are handed down from generation to generation in the minds of the rustic inhabitants of the neighbourhood. In many places the mountains on the north side of the river are lofty and rugged, and present immeasurable tracts of brown heath, and large spaces occupied with grey rocks, and scattered stones, thrown about in the most fantastic and chaotic confusion. There are deep glens and ravines, covered over with short stumpy brushwood, which renders walking both treacherous and dangerous. We stammer, however, here and there, upon spots of great beauty, which surprise and delight us for the toil of our wanderings. We meet with the elear and silvery brook at every turn of the landscape, on spots of the margin of which grows the palmy willow, drooping over the murmuring waters, as they leave the upland wastes to visit the distant ocean, and be absorbed in its bosom.

The Cluden Water is a favourite locality in the estimation of the Dumfries anglers. It has a run of about twenty miles, and is well stocked with trout, and likewise with salmon-trout, when the water is in a fit state for this particular fish. There are some small feeders of the Cluden in which there is an abundance of trout, though but of inferior size. The Cairn Water is also a good trouting stream, and will afford a fair day's sport to the tourist. Worm fishing, as well as the minnow, when the waters are suitable after summer rains, are very successful modes of sport in these tributaries of the Nith. 
On the kinds of flies commonly used on the Nith, and its dependent streams, we have little in the way of advice to give. We have here, as elsewhere, found nearly all colours, and combinations of colours, highly extolled, and successfully used. Perhaps, if a fair estimate could be made, it would be found to recommend flies of a moderate size, lightish and brownish wings for the summer months, and grey and mottled wings, with red body, for the entire spring season. But to dogmatise on the matter is little better than sheer folly. We have seen fine baskets of fish taken by country lads, in the higher sections of these waters, with the queerest looking things, in the shape of flies, that ever were seen. Nothing in the history of Entomology could approach them; and yet, strange to say, the fish seemed to take them most greedily.

Below the town of Dumfries, this fine river of Nith is navigable for small vessels. Its picturesque scenes and landscapes terminate at this spot; so likewise terminate its rod-fishing capabilities as a pastoral stream. From the town to the sea, the country is low, ill-looking, swampy, and nearly destitute of every object on which the mind rests with pleasure and satisfaction.

When the angler visits Dumfries, he must pay his tribute of respect to the memorials which are here, of the greatest of Scotland's bards-Robert Burns. He resided in this town for the last five years of his life. The house in which he took up his abode, is situated in what is now called Burns 


\section{5}

Street, and is the same dwelling in which Mrs. Burns lived till her death, in 1834. In the cemetery connected with the Clureh of St. Michael, is the Mausoleum erected to his memory. It was executed by an Italian artist; and represents the Poet at the plough, and his attendant genius throwing her "inspiring mantle" over him. Thousands of tourists visit the spot every year. His fame is ever fresh on the memories of men.

How intense, elevating, and refined, are the feelings connected with a visit to the hallowed spot of departed genius! How deeply is such a rush of thoughts-such a commotion of internal sympathies, calculated to strike the mind with surprise and admiration, at the wonderful mechanism, if we may so term it, of our spiritual frame. There seem to be two conspicuous elements in this veneration for departed worth-identity, and memory. As in the case now before us, we believe Robert Burns to be the same identical personage who sojourned, sang, died, and was buried here ; and we have perpetually before us, in our memories, what he said, and thought, and did. What a collection of living wonders is here! The mind is pinned down to the physical structure, as sternly as if it were itself a thing of flesh. It never wanders from its otwn habitation;-never passes the threshold of its own dwelling. It never fancies itself really severed from the beloved frame which it clothes, and feeds, and cherishes with such unwearied solicitude. Though there is nothing apparently in the human structure 
to imprison or confine this spiritual force-though there is no casket in which we can suppose it to be locked up securely as a piece of muslin, yet for years in sureession the mind remains the same. That this should be the case, as it really is, would have been inexplicable to us, had we not known it to be a fact, as if some had proposed to shut up a sunbeam in an apothecary's vial, or to carry about a quantity of electricity in a carpet bag. The most marvellous circumstance in connection with this view of the mind, is, that the subtle fluid and inanimate thing which we call spirit, is at the same time more distinctive, more personal, more durable, than if it were. carved out of marble, or cast in metal. Look at the faculty of memory! It is this faculty which connects us with the past, by stretching out our own consciousness over a long series of years. It is this faculty which binds the separate events of our existence, together, and assures the grave old gentleman of fourscore that he is identical with the rampant boy who used to play at leap-frog. In spite of the lapse of years, the whole spectacle may now probably be reproduced in the mind of the individual. The very process of remembering, implies that the Agent which does so, is identical with that which, twonty years before, observed the transaction so remembered. True, many circumstances in the life of man appear to grow dim-many may seem to sink into positive oblivion; but we cannot avoid the conclusion, that if the chain of our consciousness stretching across an expanse of years, distinctly 
connects the child with the man, it must be complete in every link, though many may appear to be hidden from the sight.

These are but a few-very few, of the marvels connected with man's nature. His structure scems to incarnate positive contradictions. His frame is a reservoir of different and conflicting forces. It is a mighty apparatus which knows no rest, yet exhibits no turmoil or confusion. We sit by the side of a human being, and all is calm, and scemingly motionless. It is just as if you listened at the door of an immense mill, where hundreds of processes were in progress, and yet could not catch one sound, or discern one symptom, of internal activity. That the man himself who is the scene of all these numerous operations should yet be almost unconscious of their existence, is one of the most striking and merciful paradoxes which could have been devised. And think, too, how strange that these vital movements should be kept up year after year, though the primitive impulse must long ago have been exhausted by the resistance which it continually encounters. Man being the nearest approach to a purely perpetual motion, since, spite of that resistance, his heart beats in his breast for seventy or eighty years, and at the rate of some forty millions of strokes per annum, without a single hour's holiday. Wake in the night, and still you find the trusty servant at work, beat, beat, beating. Whilst the mind seems to slumber, and the limbs to recruit, still the noble engine proceeds with its steady strokes. Through youth 
and age-through sickness and health-through growth and decay - through all the vicissitudes of existence, the gallant organ faithfully prosecutes its task, and never for a moment ceases to beat. But above all, think of the mysterious principle for which this bodily mansion was built; which yet no search has ever been able to discover in any of its apartments-which no eye has seen, no hand touched, no science probed; which enters it we know not how, which forsakes it we know not why; but which, when it departs, leaves the splendid house it inhabited a hopeless ruin, as if a soverign has scarcely died ere the palace he occupied sank into a heap of sand! Man is a compendium of marvels; a perfect mass of mysteries!

From Dumfries the angling tourist, if desirous of prosecuting his rambles to the west, through what is commonly called Gallowayshire, will find no more assistance from railway conveyances. There are two routes for angling the various interesting streams in this part of Scotland; the one by taking the mail coach road, which keeps by the sea coast, right through to Portpatrick, a distance of eighty-four miles, and fishing the rivers as he crosses them at right angles as they flow into the Solway Firth; or, he may strike right up the country, where he will meet with the same rivers in their higher localities. We have gone both routes more than once; and though both are highly interesting, we give the preference to the upland route, on account of the picturesqueness of the entire range of country. There are, un- 


\section{9}

questionably, many delightful sea views on the mail coach line of road. The waters of the Solway, the Isle of Man, the distant mountains of Cumberland, and, in clear weather, those of Ireland, afford constant objects of attention and pleasure to the traveller. But we confess we have, rod in hand, an unquenchable thirst for wild and unbeaten tracts; and if the angler has as much time to throw away, let him leave all the roads and towns on the coast, and traverse the mountainous part of the country as the "crow flies." Time to throw away, did I say. No! not thrown away, but most usefully and profitably employed. The saunterings of the angler over such lands as we have first noticed is not idleness. Thoughtless persons are apt to imagine that rambling about in fields, by the banks of rivers, listening to the cheerful song of the birds, smelling the sweetness of the flowers, and delighting in the freshness of the mountain breeze, is idleness, because there is no immediate mercenary profit. They forget that all the delights of nature-the beauties of the meadows and the forests, the balmy breath of the air wafted over the wild luxuries of the earth, the waving of the trees, the murmurings of the brooks, the shelter from the mid-day sun, the lowing of the cattle on a thousand hills, the peaceful labours of the peasant, surrounded by all these gratifications - they forget that these, when pouring their riches npon the mind of a solitary man, upon the soil prepared by the softening hand of self-examination, prove the brightest volume, the sagest lessons of ex- 


\section{0}

perience- the noblest picture of the Divine naturethe most powerful incentive to industry, that can be communicated in our brief career while here upon earth. In reading the writings of others we flag, we slumber, and we often desist from instruction to which we are not wakeful enough to hearken-hearing even the most elegant admonitions, we are not enthusiastic. Not so the admonitions which the angler sees, and hears, nay, often feels, in his wanderings. These never pall upon " the stomach of his sense." They are fresh and invested with new beauty every visit. They penetrate into his bosom, and mingle in the actions and feelings of his daily life. Every thing he has to do may be doubled-nay, rendered tenfold, by the vigour and newness of spirit communicated by his love of the "gentle craft." But whatever route the angler may find it convenient to take, we shall give a sketch of the rivers in such a manner as will, it is hoped, afford him all the information he requires.

Leaving the Nith and its tributaries, let the angler dash on to the Urr, in Kirkcudbrightshire, distance about fourteen miles. This is an excellent angling stream. It springs out of Loch Urr, on the confines of Dumfriesshire, and has a run of more than thirty miles, taking its numerous windings into calculation. It has but few feeders, and those are of little or no moment. For several miles from the loch out of which it springs, its streams are small, and, in dry seasons, not well adapted for fly-fishing. But they deepen and widen as they proceed on their 
way to the ocean; and from the neighbourhood of Kirkbride to the parish of Urr, there is a succession of good angling streams, in which fair sized trout are to be had. And indeed, the river is excellent for the rod, all the way down to the sea. There are a great many neat gentlemen's residences on its banks, and as beautiful sketches of scenery as can meet the eye in any other parts of Scotland. There is a large Roman Camp, and in good preservation, at a place called the Moat of Urr, which is well entitled to the notice of the antiquary. I have known minnow very successfully used in the Urr, during the summer months. The largest trout ever taken in it, have been captured by this seductive bait. Red and black hackle flies seem to be favourites here.

The river Dee takes precedence of all others in this county. It springs out of Loch Dee, and has a run of above forty miles. It is a capital water for common trout, salmon, salmon-trout, bull-trout; and there are likewise a few pike and perch in it. The salmon fisheries are of considerable value; and large quantities of this species of fish are taken throughout the season, and transported to London, and to the markets of neigbouring provincial towns. The river enters the sea a little below the town of Kirkcudbright.

Tarf Water enters the Dee a short distance above the town, and has a range of about ten or twelve miles. It contains a good stock of fish, and is much frequented by anglers in the vicinity. The vale through which it flows is very interesting. The Dee, 


\section{2}

from where this stream enters it, and to where it is joined by the river Ken, embraces a choice collection of fishing waters, all richly stocked with the various kinds of fish for which it is celebrated. This range of country on the Dee goes by the name of the Glen Kens, and contains many rural scenes and landscapes of singular beauty. Alexander Montgomery, the Scottish poet, who flourished in the reign of James VI., was born in this neighbourhood. In his well-known work, "The Cherry and the Slae," he describes some scenes on the river near to Tongland-hill, where it falls over some rocky eminences, in the following lines:-

$$
\begin{aligned}
& \text { "But, as I lukit me alane, } \\
& \text { I saw a river rin } \\
& \text { Out ower a steepie rock o' stane, } \\
& \text { Syne lichtit in a linn; } \\
& \text { With tumbling and rumbling } \\
& \text { Amang the rockies round; } \\
& \text { Devalling and falling } \\
& \text { Into a pit profound." }
\end{aligned}
$$

In the ancient history of Tongland Abbey, it is mentioned that the people enjoyed great sport with the salmon, which, in dry summers, could not get beyond this cataract. "Here it is," says the historian, "that the Viscount of Kenmure, as bailie of the Abbey of Tongland, hath privilege of a Bailieday, prohibiting all persons from fishing in that time, so that, on a day appointed, there is excellent pastime; the Viscount and his friends, with a multitude of other persons, coming thither to the fishing 


\section{3}

of the salmon, which, being enclosed among the rocks, men go in and catch them in great abundance with their hands, spears, yea, with their very dogs."

The stretch of water from where the Dee is joined by the river Ken, in the direction of the sea, abounds with fine fishing streams, and no angler need want sport who knows his trade, and will devote himself to it. Large baskets of trout ean be had in almost all states of the water; and I have found here, what I have often witnessed elsewhere, that strong east and north winds, though piercingly cold, when they fall fairly upon portions of still and deep water, are very favourable to the feeding of fish. I have seen them quite ravenous under such circumstances.

In this section of the Dee, immense quantities of grilse are occasionally taken. In 1836, there was caught, at one draught, three hundred and fifteen! It is chiefly in this section of the water that the large bull-trout are found, sometimes weighing upwards of twenty pounds. It is in these parts where both the Ken and the Dee flow through Loch-Kcn, that perch and pike are to be found in any quantities. It was here that one of the latter species of fish was taken with fly, of the astonishing weight of seventy-two pounds.

The Ken has a run of about twenty miles before it falls into the Dee; and in its higher portions is a very pleasant stream for trouting. Should the angler make Sanquhar a starting point for this river, he will find the public road leading into the higher parts of Kirkcudbrightshire passing close to upper 
waters of the Ken, which, when followed down a few miles, soon become fine streams for the fly. But the trout are here much smaller than in the lower sections of the stream. It has few feeders; the Deugh Water and the Garpel Burn being the principal. They are not, however, of much consequence.

There is some lake-fishing in this locality to those who are fond of it. The lochs of Grannoch, Dornal, Lochinbreck, Glentoo, and Roan, which contain trout and pike, and a few perch, will afford a fair share of sport. There is a loch in Girthon parish, in which there are large quantities of charr. Loch Brack is celebrated for its fine and large trout; and Barscobe, Houie, and Loch Skae, have a high reputation among the anglers in the neighbourhood.

The entire scenery of the upper parts of the Ken is of a singularly wild and desolate cast. We travel for miles and find no human dwelling to cheer our eye, or call forth our human sympathies. Yet this kind of country is full of interest to a contemplative mind. It produces a soft and soothing melancholy which some poets have imagined to be the highest standard of human bliss. And so, in one sense, it eertainly is. Nature is never sad; in all her phases she speaks to the heart and affections, and imparts to them the most exquisite pleasures. These heathy moors, these solitary wastes, these barren and frowning mountains, and these dells and caves, in which the human foot has seldom trodden, light up a more intense and bright flame in the breasts of men than the bustle of the great city, or the gaities of the 
ball-room. Nature's teachings are always to the purpose-always directed to self-examination, selfculture, self-government, self-gratification and improvement. Every thing she teaches, she teaches for time and eternity.

The angler will find it a most delightful ramble to go from the junction of the two rivers to the higher sources of the Dee. There is excellent trout fishing in this direction, and the country is beautiful along many parts of its banks. From the neighbourhood of Poulloch Water, which flows out of Loch Grannoch, to near the source of the stream, there is a regular succession of the finest fishing waters imaginable. The entire route is full of wild and picturesque grandeur.

We cannot leave these angling waters without noticing that, near to the junction of the Dee and Ken, there is a locality rendered sacred by the wellknown song, called "Mary's Dream." It was written in 1770 , by one John Lowe, the son of the gardener of Kenmure Castle. We are told that Burns specially visited this neighbourhood, hallowed by the outpourings of genius, and "lingered, and lingered, and lingered on the spot, as if he expected the passing spirit to appear." The author of this song fell in love with one of the daughters of a gentleman, in whose family he was a preceptor. The sister to this young lady was called Mary, and her lover was drowned at sea; and this unfortunate occurrence induced the young man to write the song in question. As it is a great favourite with the 


\section{6}

inhabitants in this part of Scotland, and a most beautiful thing in itself, we shall take the liberty of here transcribing it:-

\section{MARY'S DREAM.}

The lovely moon had climb'd the hill, Where eagle's big aboon the Dee, And, like the looks of a lovely dame,

Brought joy to everybody's ee.

$\mathbf{A}^{\prime}$ but sweet Mary deep in sleep,

Her thoughts on Sandy far at sea;

A voice drapt saftly on her ear-

"Sweet Mary, weep nae mair for me !"

She lifted up her wakening een,

To see from whence the sound might be, And there she saw young Sandy stand,

Pale, bending on her hollow ee. "0, Mary, dear, lament nae mair!

I'm in death's thraws aneath the sea ;

Thy weeping makes me sad in bliss,

Sae, Mary, weep nae mair for me !

"The wind slept when we left the bay,

But soon it waked and raised the main, And God he bore us down the deep,

Wha strave wi' him, but strave in vain.

He stretch'd his arm and took me up,

Tho' laith I was to gane but thee :

I look frae heaven aboon the storm, Sae, Mary, weep nae mair for me !

"Take aff thae bride-sheets frae thy bed, Which thou hast faulded down for meUnrobe thee of thy earthly stole-

I'll meet in heaven aboon wi' thee !" 


\section{7}

Three times the grey cock flapp'd his wing,

To mak the morning lift his ee;

And thrice the passing spirit said,

"Sweet Mary, weep nae mair for me !"

Passing from the Dee, and proceeding westward, we meet with the river Cree, which springs out of Ayrshire, passes through Loch Cree, and, after a course of about twenty miles, falls into Wigton Bay, near the town of Creetown. The Minnick enters it a little above Loch Cree, and is a good trout stream. In the higher parts of both streams, the trout are very numerous, but they run small; and the best fishing waters for the salmon and grilse are below the town of Newton Stewart.

The Blandenoch Water is one of a similar character to that of the Cree. It springs out of the same locality, runs parallel with it, and then enters Wigton Bay a few miles west of Creetown. Near to Kirkcowan, the Blahdenoch receives the Tarf Water, which comes from the same mountainous range on the borders of the county of Ayr. Both streams have a good share of trout in their higher waters, but not many salmon or salmon-trout. The scenery upon many parts of their banks is very fine and picturesque. The flies we have used in these waters have generally been of a brown and black-bodied cast. But our impression is, that the fish here are not very particular as to colour, only size is of some moment.

The Fleet and the Luce, both entering Luce Bay at a short distance from each other, are streams 


\section{8}

worth throwing a line into, though they are not of a first-rate character. We have seen the minnow a very deadly bait in both waters, in the summer months, after rain.

Turning from Gallowayshire to the right towards the north, we enter Ayrshire, a county which has some fine angling streams. If we cut through the country by the higher parts of the Cree, we shall at no very great distance fall in with the river Stinchar, which runs a course of about thirty miles. It is a good angling water, and has a fair portion of salmon. Its feeders are the Dusk, the Tig, and the Muck; in all of which a great number of small but rather rich flavoured trout are to be found. The anglers who frequent this stream use a great variety of flies; the minnow is likewise in great request in certain seasons of the year.

Should the tourist wish to have a little loch fishing, he will find several sheets of water in the localities near to the higher parts of the Minnick and Cree. These are Loch Darnal, Maberry, Chirmany, and Moam, in all of which there are trout, pike, bull-trout, perch, and several other species of bottom fish. The rural scenery in the neighbourhood of these lochs is often very beautiful and impressive, and cannot fail to yield the angler a large portion of rational pleasure and enjoyment.

If the angler has wandered with his rod through these mountainous tracts of Gallowayshire, and has had the right feelings of a genuine piscatorian, his mind will look back upon these wild regions with 


\section{9}

some degree of regret. His eye has become familiar with certain features of nature-the hills, the peaks, the dells, the gorges, the rushing waters, and the smiling but narrow valleys. They have all administered to his pleasure, whether he caught fish or not. The imagination has dwelt upon them with more or less intensity and affection; and now, when he has to bid them farewell, he feels they have obtained a hold upon his heart, which he did not previously anticipate. This is one of the grand secrets which nature teaches us, in courting and wooing her. She has an irresistible fascination about her. Her smiles, and even her frowns and scowls, have something seductively winning and engaging. She stamps her character upon our remembrances, and places it for ever before us. The rivers and the trees, the hills and the fields, are the marks she leaves on the journal of our memory. She fills us with admiration at this spot, and overawes us at that. We have derived rich stores of joy and beauty from east and west, north and south. We have revelled in luxurious feelings from nature's inexhaustible storehouse. The heavens and the earth have administered to our gratification, and filled us with lively hopes and aspirations. And now we are about to leave these spots of sublimity and grandeur, and to saunter among tamer views and champagne landscapes. The hum, and noise, and bustle of active and social life, will again engross the senses, and fill our minds with images and materials of thought, of an altogether different character. 
Coming suddenly from such pure and bracing airfrom the still sublimities of nature-the hum of a city falls upon the ear like a dream. One can scarcely realise the noise and turmoil of carts and carriages, or relish the odours from reeking gutters and cesspools, or attune our organs of hearing to the shouts and squallings of hundreds of ragged and dirty urchins, up the narrow lanes and alleys of the crowded emporium of wealth and traffic. All these things instinctively drive us back again upon ourselves; we grasp the rod, that true emblem of tranquility and peace, more firmly in the hand, and look back to the simplicity, and purity, and grandeur which enshroud all our mountain wanderings and rural contemplations.

Following along the coast, we come, at a distance of about twelve miles, to the Girvan, which springs from the hills in the neighbourhood of Barr and Straiton. One of its sources is Loch Spalander, which contains excellent and large-sized trout, with a goodly sprinkling of charr. Trolling with the minnow in this sheet of water, which is of no great extent, is very successful, at almost any part of the fishing season. The banks of the Girvan have long been highly celebrated for their fine scenery. Burns sings of "Girvan's fairy-haunted stream;" and the whole neighbourhood is more or less interesting from particular and striking incidents in Scottish history. A place called Turnberry was the property of Robert Bruce, and the spot, as Burns relates, "where Bruce ance ruled the martial ranks, and 


\section{1}

shook his Carrick spear." Here also was the farm of Shanter, belonging to Douglas Grahame, the hero of "Tam o' Shanter," which the Ayrshire bard has rendered familiar all over the world.

As an angling river, the Girvan is a pleasant water to perambulate with the rod. The streams are well adapted for throwing the line with ease and dexterity; and in the spring months they are commonly in very high condition for sport. Attention ought to be paid to the size of the flies used for this water; colour is not of so much importance.

The Doon and its feeders are classic waters in this section of the Scottish kingdom. Their streams have been immortalised by the fascinations of song. Its sources lie on the borders of Kirkcudbright, and it is connected with a chain of lochs, of which Loch Doon is the principal. The river has a run from this spot to the sea of about eighteen or twenty miles, and is altogether a very fine and interesting angling stream. Salmon, salmon-trout, the yellow and common trouts, and pike, are found in its waters. Its bed is very rocky ; and we every now and then meet with narrow gullies through which the watery element makes its way with irresistible impetuosity. The angling with fly is good nearly all the entire route, from Loch Doon to where the river joins the ocean. It is much frequented by numbers of anglers from the town of Ayr and its neighbourhood, by whom its higher waters are generally more warmly eulogised than those portions nearer the coast. Good fishing tackle is to be had in this town. 
Lake fishing in the higher parts of the Doon is very good. Loch Doon itself is a sheet of water six miles long, and about a mile in breadth. There are no less than twenty-six distinct lochs in or near to the parish of Staiton; in all of which there are more or less trout, pike, perch, \&c. In some of these lochs, such as Braden, Dercleugh, and Finlas, boats are kept for the accommodation of anglers.

This locality is interesting on account of its having been a celebrated spot for the shelter of the Presbyterians in former days; many of whom met here with cruel and savage deaths. There is a place called Ayr's Moss, where between sixty and seventy of them located themselves, determined upon resistance or death. They were attacked by a number of dragoons, and many of them killed on the spot. The scene of this bloody affair is marked by a flat monument, called Cameron's Stone.

The river Ayr has a larger range than the Doon, being nearly thirty miles in extent. It springs out of the hilly grounds about the neighbourhood of Muirkirk. It is a fair fishing stream, but does not stand so high in general estimation as the Doon. There are a few salmon and yellow trout in it. In the higher localities of the Ayr, we fall in with its two small feeders, the Garpel arid the Greenock, which have a considerable quantity of small trout; but these waters are scarcely entitled to the notice of the tourist, when other superior streams are so near and abundant. The Lugar and the Coyle likewise join the Ayr lower down towards the west. 


\section{3}

These are better tributaries than the other two first mentioned. We have seen fine trout, and in considerable numbers, taken in the Lugar, particularly with the minnow, during the summer months.

The entire valley of the Ayr is extremely interesting, both from its rural features and from the poetical associations connected with it, from its having been the birth-place of Burns, and where he spent the first twenty-five years of his life. Some of the most humorous and pathetic pieces were written on or near to the banks of the Ayr, and are descriptive of some of its well-known localities, even at this hour. It was at Mauchline, near the river, that he saw his "Highland Mary," his first love, of whom he sang,

"Ye banks, and braes, and streams around

The Castle o' Montgomerie,

Grcen be your woods and fair your flowers,

Your waters never drumlie.

There summer first unfaulds her robes,

And there they langest tarry,

For there I took my last farewell

Of my sweet Highland Mary.

"How sweetly bloom'd the gay green birk,

How rich the hawthorn's blossom,

As underneath the fragrant shade

I clasp'd her to my bosom."

*

The poet's biographers tell us that he and this object of his ardent affection "stood on each side of a small brook-they laved their hands in the limpid stream-and, holding a Bible between them, pronounced their vows to be faithful to each other." 
This Bible is, or was lately, in possession of a surviving sister of Mary, at Ardrossan. Upon the boards of the first volume, is inscribed, in Burn's handwriting, "And ye shall not swear by my name falsely, I am the Lord.-(Lev., xix., 12). On the second volume, "Thou shalt not forswear thyself, but shall perform unto the Lord thine oaths." (Mat., v., 33). And on the blank leaf of either, "Robert Burns, Mossgiel," with his free-mason mark. The parting was an eternal one. On returning to Greenock, on her way to Ayrshire, Mary Campbell died of inflammation, and was buried in the church-yard there, where there is a monument to commemorate her story.

It was in this locality of the Ayr that he afterwards wrote his famous ballad, which Mr. Lockhart says is the best he ever penned, "To Mary in Heaven."

"Thou lingering star, with lessening ray,

That lov'st to greet the early morn, Again thou usher'st in the day

My Mary from my soul was torn.

“ 0 , Mary! dear departed shade!

Where is thy blissful place of rest?

Seest thou thy lover lowly laid?

Hear'st thou the groans that rend his breast?"

Proceeding towards Glasgow, we meet with the Irvine, and its tributary, the Cessnack. The main river is not held in high repute by anglers, but its feeder has a fair portion of smallish trout. 


\section{5}

The Garnock springs from the higher lands of the county, in the vicinity of the two sheets of water called Kilbirnie and Castlesemple, both of which contain trout, perch, pike, \&c. The Garnock is considerably augmented by the waters of the Rye, Caaf, Dusk, and Lugton. There is a good sprinkling of small trout in all these feeders, but in dry seasons they become quite unfit for anything like pleasant rod-fishing. The chief river is greatly to be preferred. It falls into the sea near Irvine.

The banks of most of these waters are very beautiful, and at particular parts of their course present very rich and varied landscapes. They are a good deal frequented by anglers in the height of the fishing season, and prove a valuable auxiliary to the stock of angling streams so near to the great and increasing City of Glasgow.

The County of Renfrew is very small, and contains few waters of any note. The White Cart, the Black Cart, and the Gryfe, rise in the high moorlands, meet in one, and join the Clyde at Inchinnan. The White Cart, in its higher localities, contains a good many very fine trout; and in this neighbourhood there are several lochs: Loch Goin, Brother Loch, Black Loch, Long Loch, \&c., in all of which there are fine trout, and likewise charr. The feeders of the White Cart are Earn Burn, Kevack Burn, Auldhouse Burn, and Levern Water.

The Black Cart is, in some parts of its course, a fair fishing stream, though not exactly to our fancy. There are but few trout in it, and those of no great 


\section{6}

size. It has pike, braize, and perch. The Gryfe joins it, which has the Locher for its chief feeder.

Nearly all the rivers, and many of their chief tributaries, enumerated in this division of our work, with the exception of those situated in Galloway, are easily accessible by railway conveyance from Glasgow or Edinburgh, and likewise from the English border, by way of Carlisle. This circumstance is of great moment to the angler whose time and resources are limited. He may make a tour of many waters, and enjoy a great diversity of scenery, at a very trifling cost of money and time.

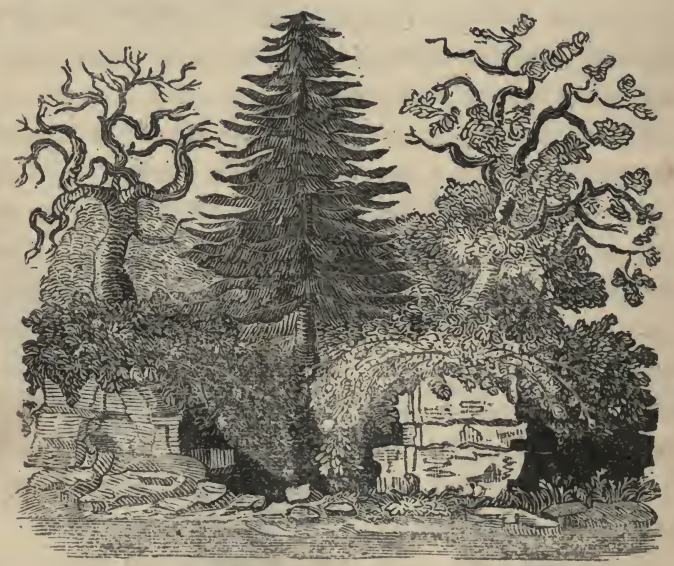




\section{PART III.}

\section{THE NORTH \& NORTH-WESTERN DIVISION.}

Embracing tue Counties of Dumbarton, Strrling, Argyle, Perte, Aberdeen, BanfF, NaIrN, INverness, Ross, SUtherLaNd, AND Caitherss.

WE are now about to enter upon our third great angling route, or, we ought rather to say, an entire series of routes, which are by far the most varied, and, to many minds, will prove the most interesting of any we have yet treated of. The vast range of waters we are now about to describe, are fitted to inspire high hopes, and heart-stirring adventures; and to those who visit, for the first time, the northern parts of the kingdom, a new sense is communicated. Never will the young angler forget the lively sensations experienced on the first glimpse of Highland scenery. The sight is unique; the feelings and emotions of delight carve out new channels for themselves; and he wonders that the refreshing and invigorating novelty should have been so long hidden from his eyes. His soul is elated beyond measure, 
98

when he scans, through the bright crimson of a setting sun, the lofty and rugged peaks of Argyleshire; and as he wanders through the narrow and rocky glens, he feels a pleasure as pure, lively, ennobling, and spiritual, as any which mortal man, in this mundane state of existence, is permitted to experience.

We beg to offer a word or two by way of explanation. As we have not undertaken to write an ordinary guide book of roads and distances, we must be excused from dwelling upon matters which are to be found in every general directory, or post-office hand-book. Our task is to point out the chief rivers and lakes which abound with salmon and trout, and which lie in the northern section of the Island. The fishing localities are so numerous here that we can do little more, in many cases, than barely enumerate them. Still we trust that what we have to say on the subject will prove useful and opportune. As our space is limited, minuteness of description cannot be indulged in; but we shall attempt to give such a faithful and general sketch as, we feel confident, will prove of advantage to most rod-fishers, and, to the comparative stranger to the country, a seasonable angling itinerary.

We may be allowed to mention, by way of introduction, and with a view to assist the sporting tourist to form a generally correct notion of the geography of this district, that the most celebrated chain of Highland mountains is that of the Grampians. It commences on the east of Loch Etive, in Argyle- 
shire, and terminates between Stonehaven and the mouth of the Dee. The most elevated portion of this chain lies at the head of this river. Ben Macdui is the highest mountain in Scotland, and rises 4,418 feet above the level of the sea. The mountains of Cairngorm, Cairntoul, and Ben Avon, are respectively 4,050,4,225, and 3,967 feet. Near to the east end of Loch Rannock is the mountain Schehallion, 3,613 feet, and Ben Lawers, on the north side of Loch Tay, is 3,945 ; Ben More, at the head of Glendochart, 3,818; Ben Lomond, on the confines of Loch Lomond, 3,191; and Ben Cruachen, at the head of Loch Awe, 3,390. Ben Nevis, commonly reputed one of the highest British mountains, lies in the vicinity of Fort-William, and is 4,358 feet above the level of the ocean. Its circumference at its base is computed at 24 miles. On the south of the Grampians, the Sidlaw, Ochil, and Campoie chains of hills cut the valleys of the Forth and Tay into three distinct portions.

Making a start with our rod and basket from Glasgow, we have a ready access, either by railway or river steamer, to the county of Dumbarton. We shall say nothing of the river Kelvin, in the immediate vicinity of the city, further than that it is a stream not worth a single rush to any angler who has the rest of Scotland before him. Well, get to Loch Lomond in a trice. The winding length of this lake is not less than four-and-twenty miles. It is narrow towards the northern extremity. On the western side the hills are well clothed with wood. 


\section{0}

A very narrow stripe of ground intervenes between the termination of the hills and the brink of the lake. The isles scattered towards the southern end of the loch present a most charming sight. They are for the most part covered with wood.

There is excellent fishing in the loch, which contains trout of great size, and a goodly portion of salmon and salmon-trout. The Leven Water, in extent about seven miles, is a piece of good fishing water. Smollett, who was born and educated in this locality, has sung the praises of the Leven in an ode, which has retained a well-merited celebrity.

" On Leven's banks, while free to rove, And tune the rural pipe to love,

I envied not the happiest swain

That ever trod the Arcadian plain.

Pure stream! in whose transparent wave

My youthful limbs I wont to lave;

No torrents strain thy limpid source,

No rocks impede thy dimpling course,

That sweetly warbles o'er its bed

With white, round, polish'd pebbles spread.

While lightly pois'd the scaly brood

In myriads cleave thy crystal flood;

The springing trout in speckled pride,

The salmon, monarch of the tide,

The ruthless pike, intent on war,

The silver eel, and mottled par.

Devolving from thy parent lake,

A charming maze thy waters make,

By bowers of birch, and groves of pine,

And edges flower'd with eglantine.

Still on thy banks so gaily green

May numerous flocks and herds be seen, 


\section{1}

And lasses chanting o'er the pail, And shepherds piping in the dale; And ancient faith that knows no guile, And industry imbrown'd with toil ; And hearts resolved, and hands prepar'd, The blessings they enjoy to guard."

Loch Lomond has several tributaries, the principal of which are the Fruin, Gudrick, Douglas, Luss, Finlass, Glenfalloch, and Inveruglass. The trout in all these streams run very small, though numerous. Anything in the shape and size of a fly will tempt them. Ten or twelve dozen of trout may be taken out of any of these feeders, in a very short space of time. To ramble on their banks is most delightful. The scenery in every direction is picturesque and imposing.

Should the angler feel disposed, a visit to the Iofty Ben Lomond will afford him inexpressible delight. In the immediate vicinity, a few lines were written on a pane of glass, in an inn, which are very descriptive, both of the mountain itself and the best mode of ascending it.

"Stranger, if o'er this pane of glass perchance, Thy roving eye should cast a casual glance; If taste for grandeur and the dread sublime Prompt thee Ben Lomond's fearful height to climb, Here gaze attention; nor with scorn refuse The friendly rhymings of a tavern muse.

For thee that muse this rude inscription plann'd, Prompted for thee her humble poet's hand. Heed thou the poet; he thy steps shall lead Safe o'er yon towering hill's aspiring head. 


\section{2}

Attentive, then, to this informing lay,

Read how he dictates as he points the way.

Trust not at first a quick advent'rous pace,

Six miles its top points gradual from the base.

Up the high rise with panting haste I pass'd,

And gained the long laborious steep at last.

More prudent thou, when once you pass the deep,

With measured pace and slow ascend the lengthen'd steep;

Oft stay thy steps, oft take the cordial drop,

And rest, 0 rest! long, long upon the top;

Where hail the breezes, nor with toilsome haste

Down the rough slope thy previous vigour waste.

So shall thy wondering sight at once survey

Vales, lakes, woods, mountains, islands, rocks, and sea ;

Huge hills that, heap'd in crowded order, stand

Stretch'd o'er the northern and the western land-

Vast lumpy groups; while Ben, who often shrouds

His loftier summit in a veil of clouds,

High $o^{\prime}$ er the rest displays superior state,

In proud pre-eminence sublimely great.

One side, all awful to the gazing eye,

Presents a steep three hundred fathoms high.

The scene tremendous shocks the startled sense

With all the pomp of dread magnificence.

All these, and more, shalt thou transported see,

And own a faithful monitor in me."

How often have we reposed under some overhanging rock on these streams in Dumbartonshire, and surveyed with interested eye, and feeling of intense pleasure, the sublime traits of nature-phenomena which fill the soul with astonishment and awe, and inspire it at the same time with heavenly ecstacy! This is a work which belongs to the Deity alone to execute. Here the mind of man rises in rapturous 


\section{3}

feelings towards the Author of all the wonders which surround him; here the most determined sceptic would be compelled to admit the existence of a Supreme Being. The most sublime of religious temples, the cathedrals, and even the magnificent and incomparable Vatican itself, where the Deity and religion display themselves in all their pomp and majesty, can never excite in the mind sentiments of faith and piety so perfect and profound as those inspired by the stupendous, transcendent, and prodigious creations of Divine Omnipotence displayed in these mountain passes.

It is not one of the least of the pleasures of the angling tourist to find, in many of those sequestered spots, such as we are now treating of, the beauties of nature, sterile and bleak as she often is, inspiring the love of song in the rural swains in the neighbourhood; and to witness how often the tender passion is awakened in the breast of the rodfisher, by rambling among the solitary haunts which his sport leads him to frequent. In angling down the Fruin lately, we met with one of those rural ditties, which pleased us much, chiefly on account of having been highly interested with the divers windings through its wild and romantic channel to where it empties itself into Loch Lomond. This is all the apology we can offer for inserting these lines here.

"Iv'e aften seen the roses blaw-

I've aften stray'd the flow'rs amang- 


\section{4}

I've aften heard, in birken shaw,

The little wood-lark's heavenly sang-

I've aften mark'd, in cloudless sky,

The progress of the rising moon-

But never ought could yield me joy

Like angling on the banks of Froon.

"'Twas here I saw a diamond bright,

Her raven hair's the jetty craw,

Her silvery neck's as pure an' white

As is the breast $o^{\prime}$ the sea maw.

The hinny drap frae aff the lip

$0^{\prime}$ this dear saint in beauty's noon,

An angel's sel' might fondly sip,

Sae sweet! the maiden of Glenfroon.

"Blind fortune, hence! I court thee not, Nor 'gainst thee shall I e'er repineGo, deal thy favours, lot by lot,

To them that kneel before thy shrine.

But night and day to heav'n I'll pray,

Until it grant me a' my boon,

Then will I clasp, in love's fond grasp,

As mine, the maiden of Glenfroon.

The Endrick is a good angling stream in the summer months after rain. We have seen large baskets of fish caught at such times in its waters. Its banks are famed as the birth-place of Napier, the discoverer of the Logarithms, and where he was engaged many years in his profound calculations.

"Th' Endrick, in wildly lyric mood,

Displays her laurel crown, And tells that, musing by her flood,

Sage Napier earned renown : 


\section{5}

That oft she paused, and marked at midnight hour The pale lamp glimmering in his ivied tower."

PROFESSOR RICHARDSON.

There are several small burns, and two or three lochs, besides Loch Lomond, in which there is fair fishing. There are trout, pike, and perch, in Loch Sloy, in the neigbourhood of Arrochar.

Stirlingshire is easily reached either by way of Glasgow, or from the Dumbarton side of the county. Its chief river is the Forth. It springs from the vicinity of the northern side of Ben Lomond, and for several miles of its course is called the Duchray. In this section of its waters, running over a barren and uninteresting range of mossy land, it is not of much fishing note. Its trout are often, however, above the average size, and always comparatively rich and highly flavoured. Light and gaudy flies are here very successful.

The waters of the Forth are greatly increased near Aberfoil from those which flow out of Loch Ard. The river again changes its name to that of Arondow; and, after running about six miles in the county of Perth, re-enters Stirlingshire, and again assumes its original designation of Forth. It receives the waters of the Teith and Allan before it reaches the town of Stirling. There is eapital salmon and trout fishing in this locality, and pike and perch are likewise to be obtained. The Corporation of Stirling own the greater part of the salmon fisheries on the water, which amount to a consider- 


\section{6}

able sum yearly. We shall notice in another place the eastern streams of this county.

Argyleshire is a district rich in numerous and varied fishing waters. Indeed, there are so many, that a formal enumeration and description of them would be both tiresome and unprofitable. The county is readily accessible from Glasgow, from whence the angler can plunge at once into the very heart of it, in a few hours, by steamers plying in every direction, and at a very trifling expense. In no part of the island is there a more interesting field for piscatory excursions than in this section of it.

If the tourist move from the Dumbarton side of the county, he may soon be in the neighbourhood of excellent fishing waters. Let him make his way to Inverary. He will be in the vicinity of Loch Fine, into which the rivers Ary and Shira fall. These are good trout streams. The fish are rich, and in fair size. The most seductive flies, in our experience, are the red and black hackles. We have known several dozens of trout taken with them in these waters, in a very short space of time.

Loch Fine is the largest arm of the sea which penetrates inland in Scotland. Its length, between Inverary and the Mull of Cantyre, is nearly one hundred miles. Near its mouth the sea communicates with many other large openings into the land. It is famous for its salmon and herring fisheries. The scenery is very beautiful in most localities. One of the most interesting objects in this neighbour- 


\section{7}

hood is Inverary Castle, the residence of the Duke of Argyle. Sir Walter Scott, in his legend of Montrose, has done ample justice to this ducal seat and the splendid scenery around it. "Embarked," says he, "on the bosom of Loch Fine, Captain Dalgetty might have admired one of the grandest scenes which nature affords. He might have noticed the rival rivers Ary and Shira, which pay tribute to the lake, each issuing from its own dark and wooded retreat. He might have marked out the soft and gentle slopes that ascend from the shores; the noble old Gothic castle, with its varied outline, embattled walls, towers, and outer and inner courts, which, so far as the picturesque is concerned, presented an aspect much more striking than the present massive and uniform mansion. He might have admired those dark woods, which, for many a mile, surrounded this strong and princely dwelling, and his eye might have dwelt on the picturesque peak of Duniquoich, starting abruptly from the lake, and raising its scathed brow into the mist of the middle sky; while a solitary watch-tower perched on its top like an eagle's nest, gave a dignity to the scene by awaking a sense of possible danger."

Douglas Water runs into Loch Finn, and is a good trout stream, though of very limited extent. There are several small burns which flow into the loch at various places, and in which fine trout are often taken with bait in the summer season after a good shower of rain.

If the angler be in the higher localities of the 


\section{8}

river Ary, Loch Awe lies only a short distance to the west, and the walk to it will be found picturesque and pleasant. Dalmally is a suitable angling station; it places the tourist in the immediate vicinity of first-rate fishing waters. Loch Awe itself is a splendid sheet of water for the rod. The most frequented sporting station on its banks is Port Sonnachan, which is twelve miles from Inverary. The lake is between five-and-twenty and thirty miles in length, bat averaging little more than a mile in breadth. It has a good supply of salmon, trout, bull-trout, pike, charr, and the sea trout. The loch is surrounded by lofty mountains of the most romantic and wild deseription, the highest of which is Ben Cruachan, whose base extends to Loch Etive, and occupies an area of full twenty square miles. The finest scenery on Loch Awe will be found at its eastern extremity. Its banks are generally sloping, well cultivated, and ornamented with timber. There are four-and-twenty small islands studded over its surface, some of which are very beautiful, and well wooded. The loch is said to be, in some parts, full seventy fathoms deep.

There is a beautiful view of the Orchy, from the old stone bridge that crosses it, near to Dalmally. The clear streams, the rich pastures, and the mountains in the distance, present as magnificent a prospect as the eye of man can rest upon.

From this point the mountain scenery is very imposing, and reminds the rambler of the romantic character of some of the valleys of the Rhine, only 
the volume of water is wanting. It exhausts all the powers of expression to do justice to the scene. Amidst a number of cultivated patches of land, encircled by the graceful sinuosities of the river, arises a conical and detached mountain. If you ascend it, you have to make your way through considerable quantities of firs and brushwood, strikingly contrasted, in many spots, with the huge blocks of barren rocks which lie interspersed among them; but when the summit is gained, a most delightful view bursts upon the eye, commanding the whole valley and cultivated grounds beneath. To see the first or last rays of a splendid sun gild the lovely picture, is a scene never to be forgotten. Casting a glance over the opposite mountains, we sce them ruggedly broken in abrupt rocks; and the imagination involuntarily moulds them into forms of towers, steeples, cottages, and the like.

The river Awe is a first-rate piece of water for salmon and trout fishing, but its extent does not exceed fire miles at the utmost. When there is a good stiff breeze on the still parts of it, very large fish can readily be taken. At the eastern extremity of the loch, there is likewise the Orchy, which is its chief feeder. It has its source in a sheet of water about fifteen miles from its mouth. It is on excellent trout and salmon stream, and the country along its banks is magnificently wild and impressive. There are sereral other short runs of water, and burns, flowing into the loch, in all of which there is abundance of fish, though of a smillewe cice than 
those found in the main waters. Gaudy flies are the favourite ones in these localities ; the size, of course, varying with the wind, the season of the year, and the state of the waters. Good and commodious inns will be found for the tourist at Dalmally, Cladish, Port Sonachan, and Bunaw. These are very agreeable and necessary things, especially to English piscatory tourists, who are generally very sensitive to all domestic comforts.

Argyleshire contains many antiquities. The ecclesiastical ruins in Iona are well entitled to especial notice. There are in Oronsa the remains of a Cistercian priory, one of the religious antiquities of the Hebrides. After those of Iona, of the ancient castles may be mentioned Dunstaffnage, at the entrance of Loch Etive, a square building, in a ruinous state, with round towers at three of the corners, having an old chapel of elegant workmanship near it; Ardterinish, or Ardternish, on the sound of Mull; Sknipnish, in Cantyre; Kilehurn, at the east end of Loch Awe, and others. There are, in different places of the coast, old "duns," or Danish forts. Druidical circles more or less complete, and cairns, are to be seen in different parts. Of natural curiosities, besides Staffa, with its basaltic columns and cave, may be noticed some singular caverns in the parishes of Loch Goyle-head and Strachur, both in Cowal.

In travelling over these mountainous tracts, and diverging any great distance from fixed and established resting places, often exposes the angler to 


\section{1}

some privations. He should make up his mind not to stand upon mere trifles as to eating and lodgment. A certain amount of uncomfortableness gives zest to one's piscatory adventures, and makes us feel more intensely grateful for a comfortable fire-side, and a full board, when we realize them. We were once ranging with a small party in this county with the rod; and, delighting in the wild freedom of going whithersoever we liked, we wandered by the sides of a good fishing stream, till we were far beyond any human habitation. We grew desperately hungry. At length we came to a little cottage, of rude and primitive construction, into which we ventured. We asked for something to eat; oat-cake was presented, but no milk, butter, nor meat of any kind. Hungry as we were, the dry oat-cake did not go down with any relish. One of the party, in prying about the corners of this rural abode, espied the entire bone of a shoulder of mutton, with a few of the integuments still hanging to it, but of real flesh there was scarcely anything. We bargained with the good wife of the house for the prize. It was laid with great care on a peat fire, dusted liberally with salt, and then divided amongst us. How keenly did the singed scrapings of the bone make us relish our oat-cake. They put us all in good humour. Mutton never had such a taste before; and we actually wished that all our legs of mutton could be made into bone. We had the essence of all animal essences-the meat next the marrow-the very penetralia of the feast. No man can form a just 


\section{2}

notion of what is meant by the fat of the land, till he has feasted off a bone of this kind, under such circumstances.

When we were done, we began to philosophise. Most men do so after being fed. We began to rummage up our knowledge of bones. We remembered that funny personage, Count Rumford, and his Essay on Bones; and likewise the story in the Persian Tales, where it is stated that a man "staid a whole year with the genii of the earth, feeding on nothing but herbs." As for the genii themselves, their common nourishment was bones; these bones made their rarest entertainments; and whilst they were grinding them with their teeth, they would cry out, "what excellent food they were." When our disquisitions had ended, and we had taken a little of the mountain dew, we made up a hash of the following lines on our rich and providential repast:

0 , noble bone! dear token of joy past, Have we not shown we lov'd thee to the last? Come ! let us tell thee, Shankie, ere we part, How like a sage philosopher thou art. Lean, insignificant, fit for the fire, We even threw thee on it in our ire. But from the ashes-like the phœnix-lo! Thou breathedst forth in re-existing glow Of flavour double strong.- 0 , glorious bone! Say, have we loved thee for thyself alone? Yet, though we've torn the meat from off thy back, And sucked the juices which thy sides now lack, An honourable bone thou art, indeed, For unto us thou wert a friend in need- 
And we would drink, if this pint were a keg,

Thy resurrection in some other leg.

And if two friends have such a bone to pick,

We hope they always may continue thick;

Nay, if they have but this one bone between them,

From every bone of discord may fate screen them;

And at their mutton, grant those friends most true

May make no bones about it, but fall to.

The distance is little more than ten miles from the eastern point of Loch Awe to the north-eastern point of Loch Etive, where the river Etive will be found. This is a fine ramble, when the weather is suitable. The river is a notable one for good fishing. It flows through a range of country, for about fifteen miles, which is at once the most impressively gloomy and grand. Everything around reminds us of the notion we commonly have of the end of time, and the universal chaos of the world. But the angling is excellent for salmon, salmon-trout, and common trout. Gaudy flies are the most in vogue on this stream. There is a rock stretching across its bed, forming a waterfall, near to Dalness, which prevents, in a great measure, salmon from ascending higher up its waters. We have known prodigious quantities of trout taken with fly above this spot. The river is by no means much frequented by anglers. Besides the Etive, the main loch has flowing into it the Kinlas, the Noe, the Liver, and the greater and lesser Esragans. These sereral streams, though of little extent, are full of small trout, but cannot always be caught with the fly. 
From the higher districts of the Etive, the distance to Loch Leven, through by the famous mountain defile, called Glencoe, is not above twelve or fourteen miles. This route the angler should take, as this is a spot of country rendered memorable by the great massacre which took place in it in $\mathbf{1 6 9 2}$ In passing through this narrow pass, the angler will fall in with the stream called the Cona, celebrated, it is said, as the birth-place of Ossian. On each side of the banks of this water, a range of lofty hills spring perpendicularly to the height of two thousand feet, throwing a shadowy gloom over the vale, which makes a deep impression on the mind of most travellers. The trout are but very small in the Cona, but when the water is in good order, they can be procured in considerable numbers.

Loch Crenan is near this part of the county, and has the Crenan river, and the Buie, Ure, Dergan, and Tendal, as supplemental waters. There is good fishing in all these places.

Should the angler set out from Glasgow by steamer, direct for Oban, he will fall in with a multitude of excellent sporting waters in the ricinity of this well known travelling station to the Western Highlands. Near the town, we have the stream called the Euchar, which springs out of Loch Scauradale, and the Oude from another lake, called Trallaig. There are ten or a dozen lochs, within a circuit of five or six miles of Oban, in which there is splendid trout fishing. There is one lake in particular, called Donolly Beg Loch, in which there is a peculiar spe- 


\section{5}

cies of trout, thick, short, very red in the flesh, and averaging about half-a-pound in weight. These are caught sometimes in considerable quantities. Loch Nell is about seren miles in circumference, and is connected by a small stream called the Clugh, with an arm of the sea, denominated Loch Feochan. In these separate waters very large trout are often taken, weighing from six to nine pounds. Salmon are likewise in abundance, and the Argyleshire banocks are to be found in great plenty. The yellow trout, weighing from four to six pounds, are very commonly met with in all the lochs and small streams in the neighbourhood. In what are termed the Black Lakes, about three miles from Oban, we have seen several dozens of sea-trout, of good size, taken in a very short space of time. There is a lake called Killyheeran, opposite to Oban, in which there is very rich, fat, red trout, in considerable quantities.

There is a large section of Argyleshire laying to the north-west of Loch Lihnne and Loch Eil, and which is known under the names of Morven, Sunart, Ardnamurchan, Ardgour, Knapdale, and Cowal, in which there is a large sphere for rod-fishing, both for salmon and trout. Loch Sunart, and two or three small streams which run into it, and Loch Shiel, which divides this county from Inverness, abound with trout of a very large size and rich flavour. All kinds of light and glaring flies are used in this division of the Highlands.

To the north of the opening of Loch Crenan lies the district of Appin, in which are the streams called 


\section{6}

the Coinich, Col, Duror, Laroch, and Leven. There are here a number of small common trout, and a few salmon, and salmon-trout, at particular seasons of the year.

There is a portion of Argyleshire, near to Glasgow, which is a good deal frequented by anglers, and it suits those who may have only a short time to spare to indulge in their favourite amusement. If the angler goes by steamer to Kilmun, he will fall in with the stream called the Euchar, which has a run of only about four or five miles out of Loch Eck, into the Holy Loch. There is an abundance of trout and grilse in it, and they take at gaudy flies with great readiness. Loch Eck itself is seven miles long, and contains, among a variety of other fish, the powan, or fresh water herring. It is said to possess the fish called in the neighbourhood goldie, known no where else; in length about five inches, and very curious on account of the succession of brilliant colours it displays before it dies.

The district known in Argyleshire as Cantyre, which stretches away to the south from the main portion of the county, contains several small streams, in which there is capital fishing, both for salmon, grilse, and trout. The chief of these rivulets, for they can scarcely be called by any other name, are Torisdale, Carradale, Saddell, Crossaig, Sunadale, Claonaig, and Skipness. The flies required here should be of a smallish size, but light and gaudy colour. There are a considerable number of small lochs scattered up and down this district, in which 
there is more or less of fine trout. The best known, and most frequented of those, is Loch-na-Break, in which very large fish have been often found.

In the Island of Bute, the angler will find Loch Fad, and Loch Ascog, good sheets of water for pike and perch. In the Grenan Loch there are large trout, but not numerous. Salmon are taken out of Loch Jorsa, in the Island of Arran; and good sized trout out of Loch Tanna. In Jura there are two or three localities for the angler, but not of any moment.

Leaving now this Highland district, we shall direct the angler's attention to the fishing grounds in the county of Perth. The chief rivers in it are the Tay, the Lyon, the Tummell, the Garry, the Almond, the Ericht, and the Earn.

The Tay rises in Breadalbane, on the frontiers of Larne. A short distance from its source, it receives the accession of several rills, which considerably augment its bulk. Soon after, it diffuses its waters into a small lake, called Loch Dochart; and, in fact, the river here bears the name of Dochart. Continuing its course from this lake, it soon expands into another loch of the name of Dochart. Here another river falls into it from the north-east. These waters are now diffused into the famous Loch Tay. Issuing from this at Kenmore, the Tay is further increased by the waters of the Lyon. It proceeds through Athol, receiving in its progress all the waters of the county, till at Logierait it is joined by the Tummel. The Tay now bends to the south, and advancing 


\section{8}

about eight miles, reaches Dunkeld, whence, taking another direction, it continues its course towards Perth, still receiving in its way the waters of several tributaries, amongst which the most considerable is the Almond. The main river then takes a southeastern course from Perth, receives the Earn, and passes by Abernethy, once the capital of the Pictish kingdom. Soon after this the river expands to the breadth of three miles, but contracting as it approaches Dundee, it flows into the German ocean.

The Tay is a splendid river for salmon and trout. The further the angler advances up the stream the better it is for rod-fishing. It winds majestically along between the mountain ranges. The noble course of this river; the magnified extent which its level situation gives to the appearance of the town of Perth; the spacious lawns, laid out with great taste and judgment; the gentle swellings of some hills, and the abrupt elevation of others; the wood which clothes their sides, or is irregularly scattered over the lower part of the country; the numerous dwellings spread throughout the scene, and the highly cultivated portions of ground-all produce a striking effect upon the eye of the stranger. $\mathrm{He}$ does not wonder why the Roman soldiers, nearly two thousand years ago, exclaimed, "The Tiber! The Tiber!"'

The county of Perth altogether is one of the most interesting to the general angler in all Scotland. The scenery on most of its streams is, in numerous localities, splendid in description. Trees of every kind 
seem to thrive well. Besides the picturesque and the beautiful, there are some of the most wild and gloomy views of nature which can be found in any part of the United Kingdom.

There are so many excellent fishing stations on the Tay, and its many important tributaries, that it would require more space than we have at command to dwell upon them individually at any length. We shall just dot down a few observations respecting them, leaving the angling tourist, when he pays the county of Perth a visit, to fill up the outline from his own experience.

Every angler has his own whims and fancies about the most eligible sections of rivers and streams. For our own part, we like the districts of the Tay which lie between Dunkeld and Kenmore best, for general trout fishing. It is a pleasant section of the water altogether, and has within its range every form of the running watery element which ean interest the practical eye of the rod-fisher.

In the Dochart and Lochay are likewise fine angling streams. We have seen fine baskets of fish taken in this direction. Almost any kind of flies will prove tempting in this district. At Killin, sixteen miles west of Kenmore, there is a waterfall, which prevents salmon from getting higher up the stream. They are often collected in great quantities in this part of the river, and the country people take them with bare hooks tied together, and let down into the water by a plummet. There is likewise a 


\section{0}

waterfall on the Lochay about three miles from its junction with the Dochart.

Loch Tay, sixteen miles in length, contains fine large trout of six and seven pounds weight, as well as salmon, pike, and charr. This sheet of water is of great depth in many parts. The Lyon river enters the Tay at the east end of the loch, and has a run of forty miles. It is a capital fishing stream for both salmon and trout.

The Tummel is an important water, and runs through a wild and interesting part of the country. It rises in the moor of Rannoch, and is for some distance called the Gauer. About eight or ten miles down, it swells to a good sized stream, where there is excellent rod-fishing. It passes through Loch Batha and Loch Lydoch. In this locality the scenery around is wild and imposing. The trout here run small.

In the vicinity of Loch Lydoch, the Ericht river joins the waters of the Tummel. This stream springs from several lakes in the vicinity and is full sixteen miles in length. There are good sized trout in all these waters; and to those who like the dreary and sterile landscapes, they can have their fancy gratified to the full. The whole country for miles round has the most inhospitable aspect imaginable.

Loch Tummel contains large trout, and the angling is very good in it. The falls of the Tummel are about four miles below the loch; they are nearly twenty feet in height, but salmon have been known 


\section{1}

to get over them. There are fine yellow trout in the river below these falls.

The Garry, springing from Loch Garry, has a run of thirty miles, and the Erochkie, the Bruar, and Tilt, are its chief feeders. There is beautiful flyfishing in all these streams, and almost any kind of flies may be successfully used.

On the banks of the Garry stands the residence of the Duke of Athol. The house was once fortified, but is now a splendid modern building. There are charming walks in the vicinity, and deep glens finely wooded. The York cascade is a magnificent object, and is most appropriately situated in the midst of beautiful scenery. Five miles south of Blair Athol is the famous pass of Killiecrankie. It is very narnow, placed between two high mountains, with the river running below, through a dark and rocky channel, overhung with thick foliage, which imparts to the whole scene a tinge of the awful and horrid. Yet, a little beyond this, the landscape opens out like fairy land, and sheds a lively and cheerful feeling over the fancy and imagination.

It is a somewhat difficult path to pursue this river into its more elevated localities. Success, however, will amply repay the trouble. We see rocks picturesquely grouped, between which the winding stream rushes and breaks with great violence. The top of these rocks, in some places, and the more level banks of the river, are clothed with shady trees on one side, and on the other are broken into steeps and rugged rocks, which compose a 
varied and romantic picture, seldom to be surpassed in these mountainous countries. The angling in all these hilly districts is excellent; and in the deep pools, which are every way met with, if ruffled with a gentle curl from any point of the compass, fine large trout can be eaught with the fly. In such places, the fish are generally found in clear weather about the skirts of the pools, especially if there be large stones in their beds, or their sides be clothed with shaded trees or bushes.

Below Dunkeld there are a number of lakes connected with the Tay, which abound with trout, pike, perch, \&c. The principal of these are Loch Ard, Loch Craiglush, Loch of the Lows, Butterstone Loch, Loch Rotnel, Loch Oishnie, Loch Cluny, and Loch Drumellie. The stream called the Braan, springing out of Loch Freuchie, contains good trout.

The river Isla, which falls into the Tay, is a fine fishing stream, in all its localities. The feeders to this water are the Dean, the Ericht, and the Sunan. These are all first-rate rod-fishing waters.

There is good fishing in the Ericht, in the vicinity of Blair-Gowrie. The beautiful valley of Strathmere is about eleven miles long and about eight wide. The windings of the river are exceedingly interesting; for they seem peeping out from intervening objects, and resemble a number of small lakes scattered over the plain.

There are the remains of several Druidical temples in the parish. At the back of the manse, in 1796, 


\section{3}

there was a mote-hill, or circular mound, where, it is said, Earl Gowrie held his regality courts. There are also some cairns, in one of which, when opened, a small stone coffin was found at the bottom; and many tumuli run through the parish. Not far from the village, commanding a fine view of Strathmere, is Newton-house, built somewhat in the style of a castle, on the foundation of the old house, in a vault of which many gentlemen were saved while it was burned down. Two modes of catching salmon are practised on the Ericht, at this place. One is by poke-nets. Towards twilight, the fishermen throw into the stream, near the Keith Falls, where it runs through deep narrow channels among the rocks, large quantities of black mould, until the water becomes muddy. Nets, in the shape of pokes or bags, are then put in the narrowest parts of the stream, and in them the salmon are caught. The other method is by pikes, or poles, and iron hooks at the ends of them, with which the fishermen, on a dark night, strike the fish the moment they are attracted to the surface by the glare of torches held from the rocks above the dark part of the stream.

The Keith falls are surprising objects in themselves. They have hollowed out deep channels in the sandstone beds, of a circular form, and of considerable dimensions. Some of these holes are thirty feet in depth, and are called by the country people, "giant's kettles," from an absurd notion that they are the results of magic. In dry weather, the salmon may be seen piled upon one another to an 
amazing depth, waiting for a fresh in the river, which they instinctively avail themselves of to ascend further up the waters.

The Earn is divided from the Tay by no very great extent of land. It is a copious stream. On its banks are to be seen some of the most sublime and extensive prospects which Scotland affords. Moncrief Hill offers a most delightful view. You see the Firth of Tay, the rich Carse of Gowrie, and the populous northern coast of Fife. Westward appear upper Strath-Earn and Strath-Tay; the mountains behind which the ancient Celthe retired before the invading armies of Rome; wide heaths ; a variety of human habitations and tracts of wood, give to the whole a rich and splendid appearance. The Earn falls into the Tay below Perth.

On this river, six miles and a half from Ardoch, there are two Roman camps; one of them at Strageath, and the other in the neigbourhood of West Dealgin Ross, near the junction of the river Ruagh Huil with the Earn. Both these stations are interesting.

Loch Earn contains fine trout, is about six miles in extent, and is encircled with beautiful scenery.

The Teith and the Allan are, properly speaking, Perthshire rivers. The Teith is a considerable stream, with a gravelly bottom, and a good stock of salmon, salmon-trout, and common trout. It springs out of the high grounds of Balquhidder, and is divided into two separate streams. The one passes through Lochs Voil and Lubnaig; and the other 
through Lochs Katrine, Achray, and Vennachar. The junction of the two is near to Callender. The Keltie, a small stream, but well stocked with trout, falls into the main water, about four miles below this town. All the lochs which the Teith flows through are well provided with traut, some of which are often taken of gigantic size. There are pike and charr, but not numerous. Trolling in these still waters is a most successful mode of taking large fish. Besides the Keltie, there are the Bracklin Burn, Stanack Burn, Loch Watston, and Loch Maghaig; in all of which there is good angling.

The Allan is a fair trout stream, but not of any great note. What fish we have seen in it have been small, and likewise poor in quality.

Should the angler be rambling on the banks of the little river Knaig, which is a feeder of the Allan, he must turn aside to the village of Aidoch, where he will find the remains of a Roman station, the most perfect in Britain. It is supposed by General Roy to have been founded by Agricola, in one of his northern campaigns. In form it is rectangular, and its dimensions are about 500 feet by 430 within the entrenchments. There are five ditches and six ramparts. This is altogether a most interesting object to the antiquarian and intelligent rod-fisher. On the road to Crieff there are several other Roman camps, of different magnitudes.

Let us pass on now to Aberdeenshire. The angling in this district is good, both for salmon and trout. The chief rivers are the Dee, the Urie, the 


\section{6}

Don, the Deveron, and the Yethan. The best fishing grounds for the fly fisher in all these rivers are towards their sources. Larger fish are usually caught nearer the sea, but greater quantities are taken in more elevated parts of the waters. The angling is here decidedly more pleasant, both for throwing the line and landing the fish.

In the summer season, and when there has been a long drought, these waters become shallow and remarkably elear. At such a season the finest tackle must be used. Small red and black palmers are the best flies for the summer evenings, in bright weather.

The Dee, though a slender stream at its source, soon becomes a considerable river, and flows through a most interesting and delightful country. The trout in its streams are uncommonly numerous, especially about fifteen miles from its origin. In the still portions of the water, when there is a fair breeze, the largest fish will be found. After a summer fresh, I have known an angler fill his basket in a couple of hours, by the use of light-winged flies and red bodies.

Nature seems to have been very lavish of many of her treasures in the valleys of this mountain stream. They possess a fertile soil, a cold but salubrious climate, hills and plains well adapted to many kinds of cultivation; while the river swarms with the trout and the salmon, and the groves and forests with deer and various kinds of wild birds of game. Here also is excellent timber, and stone of the most magnificent dimensions and quality, fit not only for 


\section{7}

the building of barns and houses, but even of temples and palaces. Here might be raised, in quick time, Saint Peter's of Rome; and the immense blocks of granite, scattered with such profusion and picturesque negligence, might, with a feeble aid of the chisel, be raised to rival the pyramids of Memphis or Palmyra. How deeply, too, does the sauntering angler feel the stillness and solitude of the whole scene! Here Zimmerman or $\mathrm{La}$ Fontaine might in reality have painted solitude, with less speculative refinement, but with more truth. Perhaps, however, these distinguished authors would not have been so generally read and esteemed; for, in everything connected with human affections and emotions, fashionable caricature and simpering affectation, will, to some extent, always claim the preeminence over nature and simplicity.

The City of Aberdeen, now easily and speedily accessible by railway, is an excellent fishing station for the tourist, because it places him in the immediate vicinity of the two chief rivers of the county - the Dee and the Don. There are good turnpike roads, which run often parallel with these rivers for considerable distances, in various sections of their course; so that he can have every facility for transporting himself to any particular part where he wishes to commence his sport.

But should the angler be in the western districts of Perthshire, he has an easy access to the higher waters of the Dee, by travelling a few miles over the mountain country in the direction of Glen Carry 


\section{8}

and Marr Forest. He must cross the Grampian chain; and by keeping a north-eastern route from the Perthshire borders, he will arrive, after a walk of about fifteen miles, at Newton, which is just upon the first waters of the Dee. The mountain range, from which it springs, is here full four thousand feet above the level of the sea. The river has a range of about one hundred miles.

Before it arrives at Balliter, a most delightfully situated village, it has received the waters of the Clunie, Gairn, Muick, Geldie, and other rivulets of less note. There is a good stock of small trout in all these feeders ; but fair rod-fishing is unfailingly found in the neighbourhood of Balliter. There are likewise in this vicinity several lochs; among the number are Brodichan, Dhu, and Muick, all famous for trout The general scenery among these lochs and streams is of the most wild and interesting kind. It makes so deep an impression on the mind of a stranger, that it is seldom forgotten for years after. It was in this locality that Lord Byron lived in his early days, and where he

— "roved, a young Highlander, o'er the dark heath, And climb'd thy steep summit, 0, Morgen, of snow,

To gaze on the torrents that thunder'd beneath,

Or the mist of the tempest that gather'd below."

Lower down the main river, the Dinnet Burn enters it near to Aboyne; and the lochs Cannord, Leys, and Dawan, are in the same neighbourhood. These contain pike and perch, but few trout. The 
streams of the Dee from Balliter to below Aboyne, are among some of the very best for rod-fishing in the entire range of the river. There are only three or four small feeders which fall into it, between here and the ocean. The angler will find accommodation and refreshments at Castleton, Balliter, Aboyne, and Kirkardine O'Neil. These several places are excellent stations for a day or two's sport. There are good artificial flies to be had both at Aberdeen and at most of the small towns and villages along the banks of the Dee.

The river Don, which enters the sea at Old Aberdeen, has a higher reputation among anglers than the Dee. It has a range of sixty miles, and springs from the high country in the vicinity of Corgraff, where there are the remains of an old castle. The Bucket and Esset are two of its first feeders, besides several smail burns or rivulets. The fishing in the main stream is good, but the trout are small. The scenery in this locality is of the most wild and striking description. The glens through which the water rushes are deep and frowning, and, in some spots, densely overhung with birch trees. In some of the deep pools, fine yellow trout are sometimes taken of a very large size.

The Urr river, which has a range of twenty miles, joins the Don at the pleasant village of Inverury. This is a stream in high repute among rodfishers. Trout of five and six pounds are often taken out of it. Its chief tributaries are the Kellack, Cal- 
pie, Shevock, and Gady; in all of which there is sometimes good fishing with worm.

Salmon fishing with the rod, in the Don and its several dependent waters, was, a few years ago, much better than it is now; but when the streams are in good trim, there is still a tolerable field for sport with the monarch of the rivers. Monymusk, Alford, Inverury, and Kintore, are stations where the tourist can obtain his wonted comforts, and be in the vicinity of good fishing waters.

Speaking of the ordinary accommodation for angling tourists in the higher parts of the Don, we well remember, some years ago, falling in with a distinguished professor at Balliter, as well known for his wit as for his skill in the "gentle craft ;" when the conversation turned upon the general want of cleanliness, both in the personal habits of the people, and in the places of "entertainment for man and beast," in this district of Scotland. Our friend the professor, to our great amusement, handled the argument much in this fashion :- "The world has long been prejudiced and addle-headed on this question. We owe everything in the world to dirtreal wealth and true liberty, from the sweating miner to the oily blacksmith-from the sailor at work to the garret-inhabiting author. Nothing valuable comes from white kids and eau-de-cologne. I can prove my point from a thousand instances. What an immense phalanx-nay, a very galaxy of dirty eminence-can we not muster! The personal negligence and snuffy nose of Frederic the Great- 
the greasy flannel jacket of Suwarrow-the filth of Charles XII., who combed his hair with his fingers, and buttered his bread with his thumbs-the queer breeches of Napoleon, and the frequent three-weeks' unwashedness of his campaigns, walking or riding all day long, with a hat like a scavenger's, and a beard like a Jew's-and even Louis XIV., the most luxurious and sumptuous of sovereigns, was so attached to his soiled shirts, that Madame de Maintenon had often to get into a violent passion before he would have clean linen brought him. And similar illustrations can be brought from every walk of life-men of business - of letters-of the fine arts. You all know Nathaniel Bentley, of Leadenhall-street, otherwise Dirty Dick, the hardwareman, who, when somebody remonstrated with him for his dirty hands, made use of the observation that Dean Swift's servant made, 'It's of no use, sir ; if I wash my hands to-day, they will be dirty again to-morrow.' Who can forget George Morland, with his apartment like a pig stye, and himself like one of the pigs? Who is not mindful of Barry - the immortal Barry-buried up to the ears in dirt, and living in an immense house, like a spider enveloped in cobwebs? Savage was dirty enough, too, not to be miscalled by his surname. It was the love of dirt that caused Prior to be so fond of smoking his pipe with a soldier and his wife in Long-acre. The feeling caused Parson to be a constant visitor at the Cyder Cellar, in Maiden Lane, and that drove Kean to the Coal-Hole. Look at Doctor Johnson coming 


\section{2}

down stairs at 12 o'clock in the day, all steaming and shining with the sweat and grease of his protracted slumbers! Now, what does this great moralist of his age, and of all coming ages, say on the matter? These are his words: 'Cleanliness, sir, is the penance which folly pays for its obedience to fashion. This wig of curtailed dimensions, and this coat of antique cut, are covered with half a century's accumulated dust. But comfort does not flow from the constant powdering, combing, and curling of the hair; neither is it to be obtained from the perpetual rubbing of the clothes-brush, nor from the idle vanity of a weekly recurrence to the tailor. Neither broad cloth nor new curls give me half so much ease as the untouched dirt of my old coat, and the uncurled dishabille of my little wig.' So, gentlemen, is it with what we see around us here. We must not conclude that all that we see neat and precise is really useful, and contributes to real happiness ; nor all that may offend our tastes and senses is pernicious and useless."

In skirting along the north-east from Aberdeen, we meet with the Ythan, the Ituna of the Romans. It springs out of the parish of Forgue, and has a run of full twenty-five miles.' It is a capital salmon and trouting stream. Its chief tributaries are the Ebrie, Brony, and Foveran, in all of which there is good rod-fishing, and the country on and around their banks is very beautiful and interesting. Loch Muckle lies near its entrance into the ocean.

Further north, at the distance of about fifteen 


\section{3}

miles, the river Ugie enters the sea, in the vicinity of Peterhead. It is divided into two branches in a certain portion of its course, called the north and south Ugies. These join at Langside, about four miles from the sea. There is a fair quantity of trout in them, and some of good size. Loch Strathbeg, lying between Fraserburgh and Rattray, contains good red and yellow trout.

Banffshire is commonly associated with Aberdeenshire. We shall join a notice of its rivers with those of Morayshire, Nairn, and Inverness-shire. These counties, for angling rambles, are all tied or laced together, and afford a wide and interesting range for piscatory recreations.

The Devoran has its rise in the hilly parts of Aberdeenshire and Banffshire, and runs a course of about thirty-five miles to the sea. It is an excellent river for sport; both for salmon and trout fishing. It has several tributaries of importance. Proceeding from its higher waters, the first stream we meet with is the Bogie, of fifteen miles' extent. It joins the main river at Rothiemay. The streams of the Bogie, which lie between Gartly and Arnhill, are very prolific of fine trout. Below Rothiemay, the feeders called the Forgue Burn, Turriff, and King Edward's Waters, enter the Devoran, and are all highly esteemed as angling streams. Light coloured flies are killing in these waters.

Passing to the north and west from the Devoran, we come to the Spey, one of the principal rivers of Scotland, possessing all the characteristies, in a high 


\section{4}

degree, of a real Highland stream. It has become of great repute among fashionable anglers of late years; and it is unquestionably a very noble water for piscatory exploits. This wild and rushing river rises out of a sheet of water called Loch Spey, near to Badenoch and Genroy, in Inverness-shire. We are told by Colonel Thornton, that there was a pike taken out of this loch of the astonishing weight of one hundred and forty-six pounds, and that he himself caught one of forty-eight. The entire length of the Spey has been variously estimated from eighty to one hundred miles. For the first twenty miles of its course, it flows through a singularly wild and mountainous region, full of interest to the lover of this kind of scenery. Before, and in the vicinity of, the small village, where the angler can find rather roughish accommodation, called Kingussie, the Spey receives the waters of three feeders, Calder, Trium, and Tromie waters, the two latter of which spring from Lochs Quich, Vroltan, and Turlich, which abound with rich and large trout. These feeders are in summer often so low that rod-fishing is out of the question; but after rain, when the waters are subsiding, it is quite marvellous what quantities of fish can be taken out of them in two or three hours. Everything that bears the most distant resemblance to a fly, is greedily seized; indeed, one grows absolutely tired with the sport. We are apt to lie down on some heathy knoll, and gaze on the shadows chasing each other along the mountain's brow. How grand are some of the sky-views in this neigh- 


\section{5}

bourhood in the months of July, August, and September? How gorgeous and rivetting to the imagination? The sun, perchance, is wheeling behind the mountains. Already his broad shade begins to fall down upon the plain. The side of the hill is solemn and sad. Its ridges stand sharp against a fine bright sky. Here and there we espy, by a strained effort of vision, a shepherd and his dog skirting their way among the heath. In various directions of the heavens we see slowly sailing continents of magnificent fleecy mountains-Alps and Andes of vapour. One you see cast upon the breast of yonder hill far to the east, while the base is radiant with the sun. This, too, has its broad shadow. Another heavy mass is moving with slow and stately grandeur along the valley, and if we rise to a little more elevated platform, we shall see the brilliant landscape growing dull in its sudden obscuration on its forward line, and growing as suddenly bright upon its rear trace. How solemnly and majestically that shadow travels up those steep and precipitous mountain sides; how it scoops down the gorge and valley; how it moves along the plain! What a fine room for study this is; more glowing and inspiring than if we had had all the invaluable contents of the Vatican library at our elbow. We have forgotten all about the fish in the stream; about flies, and lines, and salmon, and trout, and pike, and charr. We have been fishing in the clouds, and brought home a full creel for an intellectual repast, at the end of the day's journey. 


\section{6}

The Spey passes through Loch Inch, and at a short distance is joined by another feeder called Fleshie Water, which springs from the hills in the neighbourhood of the Forest of Badernoch, and has a sweep of about fifteen miles. It is a good trouting stream in the summer months, when its waters are in order. In the immediate vicinity, and connected with the Spey, are Lochs Alvie, Morlich, Rothiemurcus, Pittenlish, and Garten, which contain trout and pike in considerablequantities. The streams of the Spey from Kingussie to Aviemore, where there is an Inn for the accommodation of travellers, are of a firstrate character for rod-angling. The banks of the river in this section of its course are exceedingly beautiful. We have every here and there stripes of well-cultivated land; while in the distant landscape the Grampian mountains tower with majestic grandeur, their bases being well clothed with dense forests of waving pine, and their summits present the most bleak and inhospitable aspect.

The Dulnain river pours its waters into the Spey about a mile and-a-half above Grantown. This tributary springs out of the mountains of Manash Lea, and has a trouting range of about twelve miles. On the Banff side of the Spey, we find another of its feeders, the Aven, which runs a distance of nearly forty miles, through a highly romantic and interesting locality. Its feeders are Livet, Crombie, and Tervie waters; besides, several small lochs are connected with it, in which there are both fine trout 


\section{7}

and pike. Loch Bulg is the most highly esteemed of these mountain tarns.

The Fiddich is another of the feeders of the Spey, and is a good fishing water. The stream called the Dullen runs into it. The angler will find ample and comfortable accommodation in all the lower sections of the Spey. Our own practice as to flies, we have generally used those of a gaudy colour.

The Lossie is a pleasant fishing river. It springs from the confluence of several small rivulets or burns in the heart of the county. It runs through Loch Trevie, and is likewise connected with Lochs Dallas, Noir, and Rheninver, in all of which there are fine trout. The entire range of the Lossie is twenty-five miles; and its chief tributaries are Glen Latteragh, and the Lochly and Lenoch Burns.

When the angler crosses the Lossie, and enters into the rich plain of Moray, he will obtain a delightful glimpse of the mountains of Ross and Sutherlandshire, and the magnificent entrance into the bay of Cromarty. This is a captivating landscape.

The scenery a little below this locality is also very magnificent. In looking down the river, in the softness of a declining sun in July, we see above us on the left a high hill, with its rocky points and wooded recesses. The light flows, gleaming and touching the ground, and here and there setting on the leafage of the trees which hang over the water. The tints over the hill, assuming a more aeriel form towards the summit, become more interesting and 


\section{8}

striking; and a church steeple, in a little secluded village, wrapped in sylvan retirement, lulls the fancy into a delicious reverie. The light and waving trees and shrubs, some with large, round, distinctly pencilled up-shootings, and others with pendant and taper leares, seem to hold communion with the waters-to be invested with vitality and life, and to be the smiling, living witnesses of their play and beauty, and listeners of their soothing music.

The Findhorn rises in Inverness-shire, and runs through Morayshire near its western boundary. Great quantities of timber are floated down streams from the extensive forests in the interior of the county. A considerable number of salmon are caught in this river, but the fishery is not near so valuable as that of the Spey. When the Findhorn is in good trim, it is no uncommon achievement to kill ten or twelve dozen of good trout in a few hours. The best flies for this river are light wings, and red and black bodies; but when the fish are taking, great nicety in this particular is not requisite.

The Findhorn has a range of sixty miles. To angle this river and its tributaries is a most delightful summer tour. It rises among the Monad group of mountains in Inverness-shire. It is a wild and dashing stream, with a rocky channel, and hemmed in with bold and rugged banks, which, in some localities, stand out from the river's sides, like high walls and towers. It is likewise subject to great and sudden inundations, which sweep all before them with irresistible devastation. 
We prefer the higher waters of the stream to those near the sea. The yellow trout are to be found in tolerable abundance in some particular sections of the river. Its feeders are the Moy Water, which flows from Loch Moy, and the Bruach, from Loch Bruach; in both of which streams and lochs there is good trout. A short distance from Dulsie Bridge, the Pallanshock runs into the Findhorn, and a little lower down the Darback, which springs from Loch-an-Darb, in the vicinity of which there is a cluster of small tarns, in which good trout and pike are occasionally found. The stream called Muckle Burn, situated at the mouth of the main river, has both salmon and salmon-trout in it; and in some states or conditions of the water, large baskets of fish are taken out of it.

The Nairn lies between the Findhorn and the Moray Firth, and is a good piscatory stream. It has a range of thirty-five miles, and springs from the neighbourhood of Cairn Gregor, in the county of Inverness. It has some small feeders, but the Cawdor Burn is the principal one. The common trout, the sea-trout, and the salmon, form the staples of its waters.

Supposing that an angling tourist wishes to confine his rod exploits to the varied waters directly connected with the route of the Caledonian Canal, we shall dot down one or two sentences for his especial guidance.

Loch Linnhe is bounded on one side by the rocky uminences of Appin, and on the other by the hills of 


\section{0}

Morven, and presents, in almost every direction, scenery of the most interesting and romantic description. The neighbourhood is studded with many gentlemen's seats, some of which possess considerable interest from historical associations. Caran Ferry divides Loch Linnhe from Loch Eil. When the angler arrives at Fort William, or at the village of Maryburgh, which is near to it, he will find the river Lochy, which, if he feels inclined, he can ascend, and he will be sure to meet with abundant sport in its streams, both for salmon and trout. In no part of Scotland can a day or two be more pleasantly and successfully employed in angling, than in a ramble along the banks of this river. Here, too, stands Ben Nevis-an interesting object to all lovers of Alpine scenery. On its northern side, this cele. brated Scottish mountain is divided into two divisions or terraces; the one situated at the height of nearly 1,800 feet, and the other from this point to its summit. At the top of this first division there is a lake or tarn, in which it is said fine trout have occasionally been caught. The higher parts of the mountain present a scene of rocky and wild desola. tion. The traveller's path is intercepted in every direction by huge granitic masses, which are often so wedged together that the ascent becomes difficult, and in some spots dangerous. Here all vegetable life seems extinct, with the exception of a few Alpine plants, which may be seen fringed around the borders of some pellucid spring. There is an awful precipice on the north-eastern side, of 
nearly 1,500 feet in height. Should the atmosphere be clear, the view from the summit of the mountain is grand and extensive. We see Ben Lomond, Ben Cruachan, Ben More, Ben Lawers, and a vast variety of other less aspiring elevations, which come within the range of the visible horizon.

The angler will find Loch Lochy and Loch Oich both fair sheets of water for angling. Very large pike are often taken out of these lakes. Trout are, however, not so plentiful here, as in some other lochs in this part of the kingdom. From Loch Oich the steamboat goes on to Loch Ness, which is twenty-four miles in length, and, upon the average, about a mile and a quarter in breadth. Opposite to Fort Augustus, the river Sirff falls into it, and the angler will find this an excellent stream for the rod. Its banks are in many spots singularly wild and romantic. About midway down the loch, the river Foyers empties its waters into it, and this, too, will be found a good fishing station. The falls of this stream have been long famous. The waters dash over a cataract of 212 feet in height, and send up a sheet of spray of dazzling whiteness. Nothing can be more grand and imposing. The banks of the river abound with the most wild and stupendous rocky chasms and eminences, many of which are beautifully ornamented with the birch and the ash.

Should the angler take the entire route of the Caledonian Canal, he ought to pay a visit to the chief mountains in the district-Ben Nevis, 4,370 feet in height, and Mealfourvonie, upwards of 3,000. 
The former is separated from the great chain of the Grampians by a wild and desolate tract called Moor Rannoch. The mountain is easily ascended by the western side; and at the height of fifteen hundred feet, the prospect opens out, and displays to the traveller's eye the Paps of Jura, and several of the Hebride islands. At two thousand feet all vegetation ceases; and near the summit the snow, in considerable depth, is found throughout the whole year. From its highest point, the visible horizon embraces an area of 120 miles. The mountain of Mealfourvonie is not near so high as Ben Nevis, but it stands in an imposing locality, and is a very sublime feature of nature. "The view from the summit is of vast extent, and highly impressive. We stand in the midst of an amphitheatre of hills, old as the creation, and command a view of the Caledonian Valley, or Great Glen of Albin. The whole course of the canal, with its chain of lakes-Loch Ness, Loch Oich, and Loch Lochy-were at our feet, extending in a direct silvery line of sixty miles. Six lakes, and numerous tarns, or pools, were in front; and in the gorge, through which the river Foyers rushes, the top of the fall was visible like a white streamer. Ben Nevis, and the mountains of Skye, Kintail, Strathglass, and round to Ben Wyvis, formed a sublime rampart. All of them were more or less covered with snow, and their variously shaped peaks and forms rose tier above tier, undulating against the sky, some clear and sunny, others dark and rugged. The coldness of the atmosphere 


\section{3}

at this elevation did not permit us to stay long, and we descended, not without danger, by the western side. Birds were singing about half-way down, but we saw only the gled, or kite, wheeling about."

Inverness-shire is an excellent district for piscatory rambles and sport. The chief rivers are the Oich, the Ness, the Dundreggan, the Foyers, the Beauly, and the Clannie. There is splendid angling in all these waters for salmon and trout.

The river Ness, which connects Loch Ness with the Moray Firth, is only about eight miles in extent, but it is an excellent piece of water, particularly for salmon fishing. Great quantities of this fish have been taken out of it of late years with the rod. It is commonly in the hands of private persons, who rent it for sporting recreations. The fish take so readily here, that all kinds of flies may be used with equal chances of success. There is good accommodation in the neighbourhood for travellers.

The Beauly is a favourite river for the angler. It springs from several feeders, the chief of which are the Farrar, the Glass, and the Cannich. All these separate streams are connected with lakes, through which they pass, or rise out of. The Glass communicates with Lochs Affraric and Benevian; the Cannich runs through Loch Moyley; and the Farrar is joined with Lochs Monar and Muille. There is abundance of fine trout in all these waters. Loch Bruiach is likewise highly in repute for its charr, and for no less than seven distinct species of trout. Near to this sheet of water is Loch Neattie, 


\section{4}

which contains pike, as well as charr and trout. Lochs Gorm, Lochnambrodarg, and Loch Carnabatan, are likewise fair fishing lakes.

The fall of Kilmarac, on the Beauly, is exceedingly interesting, both to the angler and lover of nature's charms. It is one of the finest salmon leaps in the kingdom. The mountain passes are magnificent, and the scenery around picturesque. The rocks by the sides of the stream rise to a great elevation, and their bases are shaded with native timber, of rich foilage and vigorous growth. Here the eagle perches his eyry, and the wood-cat and the otter take up their abode. The salmon run with such violence up this fall that they often kill themselves with their supernatural efforts. It was here that the Frazers of Lovat, lords of the manor, were wont to entertain their guests with a voluntarily cooked salmon. A kettle was placed on the south side of the fall, and kept full of boiling water. On a portion of the rock, left dry by the waters, tents were erected for the accommodation of the visitors. Here the party waited until a luckless salmon fell into the kettle, and was cooked in their presence.

The number of salmon in this locality is, in particular seasons of the year, quite astounding. The wild cats and otters destroy a great number. There are often seventy and eighty fish taken with a small net at one haul.

In spite of the fall, or we might say falls, for there are two of them, the one about nine, and the other twelve feet high, some salmon succeed in get- 


\section{5}

ting up to the higher localities of the main river, and its chief tributaries.

We have often wondered, whilst wandering by these rivers, what the ideas of the Romans could have been, as to the nature of Scotland south of the Grampians, relative to its rich store of fish-an article of such sumptuous luxury in Rome and other cities in Italy. We think they must have been both surprised and delighted at the quantities of their most expensive food, found in such raried and rich abundance in every rivulet and mountain lake. They must have had many a luxurious meal on the salmon and trout of the Tweed, the Forth, and the Clyde. They were, without exception, the most extravagant people, in regard to fish, of whom we have any record. The accounts of their Vivaria, or fish ponds, are, to this hour, matters of surprise, amounting almost to incredulity. To keep fish became quite a mania of the wildest kind among the nobility of the country. The most wealthy and distinguished characters wasted their time and fortunes on these childish and insane projects of stews or ponds, as we may learn from Cicero, who, ironically, calls Luculus, Hortensius, and Phillippus, the "Tritons of the fish ponds." The folly extended to such a pitch, that reservoirs for fish were constructed on the roofs of dwelling-houses; while others, again, not daring to soar so high, contented themselves with bringing river water into their dining-rooms, where ressels for the reception of fish were so made, 


\section{6}

as to enable the master of the house to pick them out a few moments before they were served up at table.

Varro relates some singular particulars about the love which Hortensius had for his fish. He acted with regard to them just as misers do with respect to their money, not daring to make use of it. The orator used to buy fish at the neighbouring towns rather than use his own. Not satisfied with sparing them, by prohibiting them to be killed for his own repast, he used to have them fed very plentifully and delicately. Nor was it enough that he did not eat of the fish of his own ponds, he himself feeding them very carefully. * * * Such was Hortensius's turn of mind, that he would sooner have given the mules out of his own stable than a mullet out of his fish pond. He was equally solicitous of the health of his fish as of that of his own servants, and when any one of these was sick, he was less anxious about his having fresh water than about the ordering it for his fish.*

This old Roman writer's account of his own speculations in fish-ponds has often struck us as containing something both curious and quaint. When he was in his eightieth year, he took to writing his book on rural affairs, and he dedicated it to his wife, as it pointed out haw she would be able to make something of their farm, when his head was laid low. He says, "We have no time, my dear, to loose; if man's estate be, as we are told it is, a soap bubble at the best, much it behoves an old fellow 


\section{7}

like me, whose eightieth birth-day is at hand, speedily to put his house in order, before he departs out of life." He then proceeds to descant on a variety of farming matters, and on the advantages to be derived from economic fish ponds.

Amorg the Romans the love of fish, as an article of food, was likewise quite a passion. Pliny tells us that the great epicures among this people preferred the scare to erery other kind of fish. The eel-pout, or lotos-liver, was the next in estimation. The red mullet was in high favour, from the fact, that when the scales are removed from this fish, it still retains a fine pink colour. "The fops of Rome having remarked that, at the death, this colour passed through a succession of the most beautiful shades, the poor mullet was served alive, inclosed in a glass ressel ; and the guests, attentive and greedy of emotions, enjoyed this cruel spectacle, which presented to them a gradation of colours which insensibly disappeared."* It is further stated, in reference to this fish, that "the greatest sensualists killed it in brine, and Apicius was the first who invented this kind of luxury. The brine most in use, in such cases, was made with the blood of mackerel, and that was one of the varieties of that famous garum, so highly praised by the Latin authors, and which was to them, at that period, what the fish sauces of the English are now." $†$

* Seneca. Quœet. Naturel, 3, 17, 18.

+ Soyer's Pantropheon, p. 213. 


\section{8}

Apicius offered a prize to any one who would invent a new brine, made with the liver of red mullets. Jurenal informs us that Asinius Celer offered sixty pounds for one of these fish which weighed six pounds.*

In the reign of Domitian, there was a prodigious large turbot eaught, such as had never before been seen. It was ordered to the imperial kitchen. The Emperor convoked the Senate to consider in what dish it should be cooked, and served up entire. The deliberation was long and stormy; all Rome was in a state of excitement by the debate; and the august body of Senators endeavoured to prove itself worthy of the confidence reposed in them by Crsar. They were unanimous in their resolutions that a dish should be made expressly for this enormous fish, since there were none large enough ready made; and also that a stove should be constructed sufficiently eapacious to allow the dish to be conveniently placed upon it. The Emperor, the city, and the whole court, applauded the singular sagacity of the Senate; and "le turbot fut mis a la sauce piquant."

Many of the Latin poets make allusions to these extravagant whims about fish.

"Grandes rhombi patinæque

Grande ferunt una cum damno dedecus."

HOR.

"Quamvis lata gerat patella rhombum, Rhombus latior est tamen patellas."

MART.

* Juvenal, 4, 11. 


\section{9}

"Great turbots and late suppers lead

To debt, disgrace, and abject need.

The border of the broadest dish

Lay hid beneath the monster fish."

In the southern sections of the county of Inverness, there are several lochs and small streams, more or less connected with them, in which there is an abundance of fish. The chief of these inland lakes are Loch Quoich, Loch Arkop, Loch Chinie, Loch Shiel, Loch Eylt, Loch Duich, Loch Marrer, Loch Hourn, and Loch Alsh. There are likewise a few small lakes and rivulets in the Isle of Sky, separated from the main land of Inverness-shire by the narrow strait called the Sound of Sleat, which will afford the tourist some sport. The seenery of the island, which is forty-five miles in length, and about five or six in breadth, is magnificent, and certainly not surpassed by any portion of the Highlands. Portree is the principal town, but the angler may obtain accommodation at Broadford, Stein, and Kyle-akin. We once saw a most splendid basket of red trout taken out of the streams in the vicinity of Portree, averaging upwards of three quarters of a pound each. They were all captured by gaudy flies.

When the angler is on the Beauly, he is little more than a stone throw from the rivers of Ross and Cromarty The chief of these is the Conan, which traverses a section of the county of five-and-thirty miles in extent. It springs out of a lake called Loch Roshk, or Chroisg, situated in the most wild and unfrequented part of this Highland district. 


\section{0}

The entire valley of the Conan presents a constant succession of splendid scenery-rapid and abrupt alternations of sublimity and beauty.

From the source of the river to where it is joined by the stream the Meig, a little below Upper Scatwell, the fishing is excellent, both in the main stream and in the lakes through which it passes. In this route the angler will come to a small lake called Loch Ledgowan, containing large trout and pike, and near to which is Loch Achin, in high repute among those anglers who delight in trolling for large fish. Three or four miles to the west of Straith Bran lies Loch Fannich, or Fannish, twelve miles in length, and abounding with large and splendid fish. The Conan runs through Loch Luichart, a sheet of water about six miles in extent, in which there is eapital angling. Not far below, there is a grand and imposing waterfall, which effectually prevents salmon from ascending any higher up the river. The Meig has a run of fifteen miles; it flows through Loch Benachan, and abounds with a vast multitude of smallish but rich trout. To designate its banks as wild and romantic, are but poor terms for conveying anything like an adequate conception of them. They must be rambled over to be known, and their varied beauties appreciated.

From the junction of the Meig to Mruirtown, there is a succession of fine stretches of angling water; and large fish are often taken out of them. The stream called the Rasay, or Black Water, enters the chief river a little below this place. It springs 
out of a stretch of country called Strath-Vaich, near to which Lochs Broom, Tolimuir, and Garragan are situated, in all of which there are good trout and pike. The stream itself forms several small lakes in its route, which abound with trout and pike of great size, and in which there is capital sport with the rod at almost all times of the fishing season. The Falls of Rossie, on the Rasay, are beautiful. Salmon, when the floods are great, can get above them, but this is not often. As the angler approaches near to the sea, the Conan affords a rich field for sport in finnocks at certain seasons, and in sea-trout and grilse. The fish take the fly very readily in these waters. We have seen all kinds of colours used.

The stream called the Orrin enters the Conan three miles below Contin. It is a good trout stream, has a run of fifteen miles, and springs out of the high grounds of Glen Orrin. Its banks are singularly romantic and interesting. The Peffery Burn, near Dingwall, the Ault-graad and Skiack, in the vicinity of Kiltearn, and the Balnagown and Alness Waters, are all more or less abundant with trout and salmon, and are much frequented by anglers in the neighbourhood. Loch Glass, about six miles long, and Loch Moir, about four, contain very large trout.

In the western parts of the county, in the parishes of Loch Carron, Applecross, Gairloch, and Loch Broom, there are fine sheets of water, well stocked with trout and pike, and some with salmon. The chicf of these fishing waters are Loch Ling, Loch Carron, into which the river Carron flows, after a 
run of twelve miles, through a hilly and wild district, Loch Taniff, Loch Maree, Loch Fuir, Loch-na Shallag, and Loch Broom.

There are good accommodations in the various localities of Ross-shire where angling tourists frequent. We remember of once getting some trout cooked at an inn at Stittingham, the deliciousness of which still lingers on theassociations of our palate, and nearly makes one in love with the Roman Catholic's forty days' penance on fish. By the way, what curious records of legislation these sumptuarylaws appear to us now-a-days, relative to the use of fish, and which were in full force for a long period both in England and in France? Under the reign of Edward II., certain fish never appeared in England but on the table of the king; they were prohibited to all others. In 1138, Stephen wanted to modify this exclusive right; but, after his death, it was again revived, and consideręd as a royal prerogative.

In former times there was a remarkable consumption of fish in England on the 4th July, the festival of St. Ulric. This is mentioned by Barnaby Gouge, in the following lines:-

\section{ST. HULDYCHE.}

"Wheresoever IIuldyche hath a place, the people there bring in

Both capes and pykes, and mullets fat, his favour here to win. Amid the Chureh there sitteth one, and to the aultar nie, That selleth fish, and so good cheep, that every man may buie;

Nor anything he loseth here, bestowing thus his paine, 


\section{3}

For when it hath been offered once, 't is brought to him againe, That twise or thrise he selles the same, vngodlinesse such gaine Both still bring in, and plentiously the kitchen doth maintaine. Whence comes this same religion newe? What kind of God is this?

Some Huldyche here, that so desires and so delightes in fishe."*

The sumptuary enactments of Edward VI. and Elizabeth were as stringent as in the days of Papal ascendency. The statutes of Edward (cap. 6) aim at maintaining with great rigour the better observance of Fridays and Saturdays, and other days of accustomed abstinenee; and likewise for other two purposes: that fishermen may be set to work, and that much flesh may be saved, and increased. In addition to Fridays and Saturdays, Elizabeth added Wednesdays, allowing, however, on this day, one dish of flesh, providing there were consumed at the same meal three dishes of sea-fish. At certain seasons this indulgence did not extend to beef or veal.

The sumptuary laws of France ordained (129t) that a meagre-dinner should consist of two herringpottages, and only one sort of fish. Louis XII., who was a great epicure, appointed six fishmongers to supply his table with fresh-water fish; Francis I. had twenty-two, and Henry the Great twenty-four. In the reign of Louis XIV., there was quite a mania about fish, chiefly from the circumstance that one of the royal cooks to the monarch had acquired the marvellous talent of cooking all kinds of fish so as to taste like the most delicate game. And we have a

* The Popish Kingdome, fol. 55. 


\section{4}

story grounded on this circumstance respecting Vatel, one of the most illustrious officers of the Prince of Conde. This Major-domo understood that a dinner without fish was a heartless and cheerless one. One day, when his noble master entertained Louis XIV. at a royal banquet, at Chantilly, which the genius of Vatel rendered more brilliant, the fish from the coast failed; he sent everywhere, but none could be procured. He was at his wit's end; he met his august master, whose kind words, full of benevolence, only served to increase his distress and bewilderment. He left him; ran to his chamber, took his sword, and three times pierced his heart! Shortly after fish arrived from all quarters; Vatel was called-no Vatel! He was sought for, and at last discovered-Vatel was no more!

The County of Sutherland presents a splendid range for the angler. It embraces an extent of between sixty and serenty miles in length, by nearly fifty in extreme breadth. To perambulate this distriet fairly and fully with the rod in hand, is the work of an entire fishing season. Where time and opportunity allow this to be done, it will prove one of the richest piscatory treats that a sportsman can meet with in any part of the world. To accomplish this task pleasantly, and really beneficially, there is nothing like walking; and next to this, a Highland Pony; - an assistant which gets you over the ground more rapidly, and diminishes the quantum of bodily fatigue. But it must be borne in mind that, with a horse of any kind, the 


\section{5}

tourist is oftcn prevented from exploring particular spots of the country possessing great attractions and beauties, and by the necessity he is under, of always looking after his stced, no matter what may be the bent of his movements, he is often compelled to go in one direction when his inclination leads him in another. A horse only bears our burden occasionally, but we have to bear his constantly.

In passing out of Ross-shire, we meet with the Oikel, which falls into the Darnoch Firth, and which is a first-rate angling water. It springs out of a district the perfect beau ideal of wildness, loneliness, and chaos;-out, in fact, of Loch Ailsh, which has itself fine trout and pike, and which is surrounded by some of the most striking scenery the eye of man can rest upon. The entire length of the Oikel is thirty miles. There is a good turnpike-road by its banks for full twenty miles of this distance, so that the angler has every facility for traversing its streams in any direction he pleases. The higher up the river, the better it is for trout fishing; and the number of salmon caught in its waters is often prodigiouscounted, in the language of Billingsgate market, by hundreds, and by tons weight.

Not far from the source of the Oikel, and in the vicinity of Ben More, is one of its tributaries called the Casley, which springs out of the high grounds in Assint, and has a run of about fifteen miles before it joins the main river. The Casley receives the waters of several burns or rivulets, which are themselves excellent fishing waters after summer floods. 


\section{6}

The stream is in high repute among scientific anglers, both for salmon and trout.

When the angler is in this district, it will save him time and labour to turn to the west corner of the county, and visit the singular group of lakes in this neighbourhood, all within a circle of perhaps thirty miles. These isolated and independent sheets of water amount to upwards of two hundred in number, varying in extent from one to fourtecn miles each. One of the most interesting is Loch Assint, seren miles long, and embellished with the most romantic and beautiful scenery. The lake is full of very large and rich trout, as well as of salmon, and the salmo ferox. This is a favourite trolling locality, and very heavy fish are taken by this mode with the assistance of a boat. But fine baskets of red trout can be rearlily obtained by fishing the edges of the lake, without any sailing aid whatever. This loch receives the waters of the rivers Loanan and Traligill, with those of some smaller burns. There is capital fishing in all these tributary waters. The river Inver flows out of Loch Assint, runs a distance of five miles, and then falls into Loch Invers. There is splendid rod-fishing here for both salmon and trout, the latter being of considerable size and of delicious flavour. The Kirkaig is a short stream, but full of fish.

Crossing the country from the vicinity of Loch Errard to Loch Ardvar, the angler will pass through among the most interesting of these numerous sheets of water. He may pass a whole week in this district 


\section{7}

with the rod, and not half exhaust the objects of interest which, to a real fisherman, it furnishes in every direction.

We have often wondered, in travelling through these Highland counties, whether there are any great number of traditionary songs on, or descriptions of angling sports among the Grlic race. Though we have occasionally mentioned the subject to persons likely to know something on the matter, yet our information has hitherto been very scanty. We have heard of one Gælic song which, in English, is to the following purport. It is said to be the production of the thirteenth century.

Oh ! set me down by the river's brink,

Which rushes along with giant speed;

Beneath yon rugged rock,

There the majestic salmon leaps.

There down the gushing stream he speeds

His way like king of fish ;

And hurries past yon ivied tower, And bends his way to ocean's bed.

When summer floods and rains fall, When summer suns shall warm the banks, The salmon spear shall again be used, To kill our noble game.

There are said to be some relics of Gælic songs which allude to one of the modes of fishing pursued by the monks in the priory of Augustines, situated in Loch Tay, and founded by Alexander I. in 1122. The mode of fishing in question was by the employ- 


\section{8}

ment of Geese as decoys. A modern writer describes this piscatory dodge in the following terms:-

"It was fishing with Geese. A line with a baited hook was tied to the leg of a goose, which, thus accoutered, was made to swim in water of a proper depth. A boat containing a party - male and female -lord and lady fair-escorted this formidable knighterrant. By and by, he falls in with an adventure. A marauding pike, taking hold of the bait, puts his mettle to the test. A combat ensues, in which, by a display on the part of both contending heroes, of much strength and agility, the sympathetic hopes and fears of the anxious lookers-on are alternately called into lively exercise, until, at length, the longnecked, loud-shouting, feather-cinctured, web-footed champion, vanquishing his wide-mouthed, sharptoothed, far-darting, scale-armed foe, drags him a prisoner in triumph. This merry doing of the good old times has, alas! gone out of fashion in this degenerate age."

The river Carron, which enters the Darnoch Firth at Bonar Bridge, is a good stream. It has its source from Loch Charrh, and other small sheets of water, all of which contain large trout. Lochs Culrain and Migdale are in the neighbourhood of Bonar Bridge, where there is a good Inn for the tourist's accommodation.

The river Shine is in great vogue among modern anglers, especially with those who visit it from the south. And indeed it is well entitled to all the commendations bestowed upon it. It has, as a river, 
only a run of seven miles, as it flows out of Loch Shine, a long sheet of water which has more than a dozen small feeders, or rivulets, and which contains fine trout, salmon, the salmo ferox, and charr. There are two falls in the Shine. The lower parts of the stream embrace the most favourite stretches of water for the salmon angler, and where, indeed, the larger kinds of trout are taken.

Loch Shine, twenty-four miles in length, is connected with a number of smaller lakes, which, except for a distance of a few miles, unite it with the ocean. By a walk from the head of the loch, or more properly from Loch Merkeland, the angler will reach Loch Mose, which is joined by a short stretch of running water, and from thence to Loch Laxford, a part of the Atlantic. There is splendid angling in all this watery expanse. It is chiefly by trolling, and the use of the boat, that the largest fish are captured. The two streams called the Tyrie, and Faig, which run into Loch Shine, are full of small trout, great quantities of which ean readily be obtained after summer rains. There is a small river called the Evlix, having a run of ten miles, falls into the sea at Darnoch, a royal borough, but a bleak and miserable looking place. There are salmon and trout in the stream.

It is in the Tyrie and Faig that the experiments have been recently carried on by Mr. Young, of Inverness-shire, of transferring the salmon spawn into localities where the fish is not formed. Those experiments have been partially successful. This mode 


\section{0}

of stocking rivers was practised two thousand years ago, by the Romans, and is largely treated of by Columella, and others. After a lapse of many centuries it has been revived again, and with great suceess, in France. Two fishermen of the Vosges, named Gehin and Remy, have sueeeeded in propagating salmon, carp, pike, tench, and perch, and they maintain that the plan is applicable to those fish which live partly in fresh water, and partly in the sea, as well as to those that live entirely in fresh water rivers and lakes. The streams and rivers over a large extent of France, have now been abundantly stocked with a variety of fish from this ancient process; more particularly in the vicinity of Allevard, Vazille, Pontcharra, Sessenage, Veary, Bourg D'Oisons Rivis, Pont-en-Royans, Paladru, Lemps, St. George, Avandon, La Buisse, Grenoble, and in many other departments of the Allier, the Lozere, the Meuse, the Meusthe, and Haut Laone.

At the moment we are perusing these lines, we eopy from the pages of a public Journal, that this mode of propagating salmon, is being adopted on the Tay, in Scotland, on a large seale. As the aecount must be interesting to all anglers, we make make no apology for transfering it here as it is given :-

"The Salmon Manufactory on the Tay.-The ponds for this purpose are situated on the river bank, near Storemountfield, the spawning-boxes being 16 feet above the summer level of the river. The water which supplies the ponds is taken from Storemountfield lake (but owing to the impurity of the Tay during spates, a supply is also to be taken from a 


\section{1}

neighbouring spring), by a pipe with a valve, into a filtering pond ; thence it is carried by a canal along the upper end of the spawning-boxes, through which it runs. These boxes are 84 feet long by ope foot six inches broad, and three deep. They are placed with a fall of six inches, so as to allow the water to flow freely through them, and are partly filled, first with a laying of fine gravel, next coarser, and lastly with stones somewhat coarser than road metal. In distributing the ova, it is gradually poured out of the vessel at the upper end of the box. The water flowing downwards carries it among the stones, under which it settles down, and by gently applying a few buckets of water at the upper end of the boxes the ova are taken down and distributed equally among the gravel. When the young fry are in a proper state, they are allowed to escape into a pond situate at a foot lower level than the boxes, where they will be fed, and allowed to remain, until such time as they are in a fit state to be turned into the river. This pond is not yet made, but will be finished by the time the fry are hatched. Great care has been taken to prevent any animal entering with the water that would prey upon the young fish. Mr. Ramsbottom, from Clitheroe (who has experimented successfully for the Messrs. Ashworth, on the Lough Corrib waters, in Ireland), has the sole management of the Tay ponds. Saturday was a remarkably fine day for the season, and we were privileged in being present at the operation of stripping the fish. When we arrived Mr. Ramsbottom had already got about 15,000 ova in round tin cans, and he showed us an ovalshaped tin box with a lid, which contained a small male fish. swimming in water, which, he said, was waiting for his mate. Presently the net was shot in the Tay at the mouth of the Almond, when two fine female fish ripe for spawning, from 18 to 20 pounds' weight, along with a small male fish, were caught. Mr. Ramsbottom having taken the largest female in his left hand, drew his fingers down both sides of the belly of the fish, when the ova flowed in a stream into the tin box formerly mentioned, in which there were a few inches of water. The 


\section{2}

fish was instantly returned to the river, and, after a short time, sailed off as if nothing had happened to it. After the ova had been washed, by water being poured on and off - care being taken never to allow it to be exposed to the airthe male fish was brought (which all this time had been in the river under a fold of the net), and manipulated in the same manner as the female, only a small portion of the milt being required. On the milt being shed a slight change was seen to take place in the colour of the ova, which became paler. Water was again poured on and off, when the operation was complete. The ova were then poured into round tin cases and carried to the ponds. When we left the river side upwards of 400,000 ova in fine condition had been obtained. We observed that a few of the ova, after impregnation, turned white, instead of being a fine salmon colour. Mr. Ramsbottom said they were barren ova. In the month of March the fry will have burst their shells, when we hope to report further."

The Fleet runs into Loch Fleet, an arm of the sea. It has only a range of twelve miles There is another stream which passes through Loch Buie, and which falls into the same estuary. There is good fishing in this locality.

The river Brora has a course of twenty miles, and rises in the vicinity of Ben Clibrig. It is joined by another considerable stream, called Strathbeg Water, or Black Water, which has its springs near to Loch Furan. Soon after their junction, they enter Loch Brara, and emerging from it, flow into the sea at the village of Brara. This loch, as well as Loch Tubernach, in the same vicinity, have both salmon and large trout, of delicious flavour. In dry seasons, the higher waters of the Brora and Black Water become very much diminished, and the angling with 
fly suffers then considerably. A ramble by the banks of these streams is, however, a great luxury, for the scenery in many parts of their course is wild and romantic beyond description.

The river Helmsdale is twenty miles in extent, and has its rise from Loch Macayn, then flows through Loch Baden, where a little below it is joined by the Ellec Water, which is itself connected with three mountain lochs, all of which are said to be well stocked with trout and pike-the latter of very large size. Lochs Leam-na-Clavan, Carr, and Loch-in-Ruar, contain fine trout and charr. The Helmsdale river, taken altogether, is an excellent one for general angling sports.

Going north a fow miles from the higher streams of the Black Water, we soon reach the springs of the Halladale, which flows into the North Sea. Its length is about twenty miles. Near to it are Lochna-Coorach, Loch-na-Sealy, and Loch Balligill; all containing fine red trout. In the same neighbourhood lies Loch Arron, likewise celebrated for its good trouting.

The river Strathy runs parallel with the Halladale, at only a few miles' distance. It is equally as large as the latter stream. It contains salmon, grilse, and fine large trout. The angling in the higher waters of the Strathy is excellent, when the waters are in full trim.

Keeping by the north coast, we soon, on leaving the Strathy, fall in with the Naver river, which springs from Loch Naver; a sheet of water seven 


\section{4}

miles long, and which contains salmon, grilse, and trout. The Naver is a favourite water for the rod, and the scenery on its banks is exceedingly beautiful. Its tributaries are the Mallart, Skelpick Burn, and Langdale Burn.

The Borgie river rises out of Loch Elam, and is connected with Loch Cragie, and Loch Looghal. There are salmon, grilse, and yellow trout in these waters, and, in general, very good rod fishing.

One of the richest treats which an angler, with any spark of sentimentality about him, can have in this district, is to ascend one of the lofty mountains in the vicinity, and take a look at the setting sun in the month of August or September. How splendidly does the luminary sink beneath the mighty waves of the Atlantic! The heavens melt into a magnificent softness.

"But lo! the day declines, and to his couch The sun is wheeling. What a world of pomp The heavens put on in homage to his power!

Romance hath never hung a richer sky, Or sea of sunshine, $o^{\prime}$ er whose yellow deep Triumphal barks of beauteous form career, As though the clouds held festival, to hail Their god of glory to his western home."*

What constant pleasures a man may derive from the contemplation of the sky! What wonderful pictures are daily-nay, almost momentarily, presented to his eye-pictures, in fact, which throw into the shades of utter insignificancy, the most

- Poems, by the Rev. Robert Montgomery. 1853. 


\section{5}

elaborate and finished productions of human genius and skill. Yet these splendid and ever gorgeous sights pass away unheeded and unrecognised by millions of our race. They cause neither surprise, nor emotion, nor sentiment, nor thanksgiving. They seem displays of artistic skill entirely thrown away upon the greatest number of mankind, either because they lack education towards such things, or lack a sensibility that developes itself without any education at all.

Were there an artist to come among us who could stand in Exeter Hall, in the presence of a living assembly, and work with such marvellous celerity and genius, that, in half an hour, there would glow from his canvas a gorgeous sunset, such as flushes the western Highlands in the autumn, and then, when the spectators had gazed their fill, should rub it hastily out, and overlay it in a twenty minutes' work, with another picture, such as we often see after sunset-its silver white, its faint apple green, its pink, its yellow, its orange hues, imperceptibly mingling into grays, and the black blue of the upper arch of the heavens, to be rubbed out again, and succeeded by pictures of clouds-all, or any of those extraordinary combinations of grandeur, in form and in colour, that makes one tremble to stand and look up,- - these again to be followed by vivid portraitures of more calm atmospheric conditions of the heavens, without form or vapour, and so on endlessly-such a man would be followed by eager crowds, his works lauded, and he himself called a god. He would be 


\section{6}

a god. Such is the Deity. So he fills the heavens with pictures, strikes through them with effacement, that he may find room for the expression of the endless riches of the Divine ideas of beauty and majesty.

The Kinloch, a short stream, runs into the Kyle of Tongues. The Rhians Burn contains a number of small trout.

The Hope and the Strathmore streams enter Loch Hope. The Grudie falls into the Kyle of Durness, a good fishing water for salmon and trout. The lochs in this vicinity are Dionard, Borralie, and Crosbole. The small streams called the Shinery and Kearvaig waters enter the ocean near to Cape Wrath, and are full of fish.

Turning to the west, we meet with several lakes in which there is first-rate fishing; but they all present the same leading features as those we have just mentioned. The entire range of coast in the western side of Sutherlandshire is one continued chain of angling waters. The chief of these are the Inchard river, Loch Loxford, Loch Stack, and Lochs Leadvuam, Dhu, and Cuil.

The benefits, in point of health, which an angler derives from his daily perambulations among the lakes and rivers in such a country as that we have just gone over, are incalculable. He grows stronger and stronger daily. He seems to get a new lease of his life; - to obtain a firmer grasp of his earthly tenure of office. The vital principle seems inspired with a renewed energy and vigour. By the way, what an active and mysterious agent this principle is, 
of which we are constantly talking, and pretending to regulate and direct. When we come to dwell upon it, we become dreadfully puzzled and perplexed, and are apt to think we are making use of a word to which there is attached no real meaningno material or tangible representative in the nature of things. But let us for a moment attend to a few of the many striking facts involved in the structure and constitution of man. There is no single object in this globe which contains such a collection of wonders as the frame of the meanest mortal. If any plant is a great problem-if any insect is a liviug mystery-if every animal is a riddle which no man can fully read, we might fairly assume that a structure where mind and matter were to meet; -where dust was for the first time to be fitted up as a mansion for spirit, would prove to be a stupendous prodigy of skill. And in whatever light we choose to regard it-whether as a complicated machine whose organs have been set for a run of three score years and ten;-or as a great laboratory in which chemical operations proceed with far more precision than in crucibles and glass retorts; this must be always our conclusion-that an apparatus which has been planned with so much wisdom,which has been designed for such a multitude of purposes-must be a perfect miracle in the flesh.

Let us for a moment glance at the materials of which the human body is constructed. We speak not of the simple nor the ultimate materials. If a chemist catch a man, and thrust him into a retort, 


\section{8}

and subject him to distillation, he would find that the patient consisted of some of the commonest elemonts which are to be found on the globe. It is the same with all human forms, from the loftiest to the lowliest. Dukes and Duchesses-coalheavers and washerwomen-might all be resolved into the same common-place elements. A Prince in a retort would yield the same produce as a clown, Differing as most men do in other particulars, in this there is no distinction. All are a compilation of the same sub. stances.

But though the ultimate elements of which humanity consists, are thus plain and ordinary, they are under the management and control of a subtle power, which, without knowing its true nature, we are accustomed to call the vITAL PRINCIPLE. There is something pervading the structure which does not belong to these elements in their inanimate uses and states. What this mysterious principle of life may be, in its intrinsic nature, it would be idle to surmise. But we may form some conception of its offices by remembering the changes which occur when the body has ceased to breathe. How is it that the frame be. gins then to dissolve? How is it that the elements of which it was compounded, then break into open insurrection, as it were, and dash off to the four winds of heaven? It is elear that all along they have been ruled by some powerful force-they must have been kept in a state of positive coercion by the principle of life. Just withdraw the principle of vitality, and a series of changes set in, which dissi- 


\section{9}

pate the body as certainly as a dew-drop is dried up in the fire of a midsummer day. The process of decomposition is no forced, artificial work; it is as much a matter of chemical routine as the withering of a leaf or flower. This singular property called vitality - which we cannot see, cannot weigh, cannot handle, cannot govern-this viewless something alone stands between man and downright decomposition.

A grand series of changes and fluctuations are constantly in progress among the materials of the human frame. This living principle has not only to keep down the conflicting affinities which may ever be on the watch for the mastery, but it has to preside over the incessant alternations which are occurring in the entire structure. These changes are twofold: first, those of growth ; and, secondly, those of repair or renewal. If we consider the body as a digestive and reconstructive apparatus merely, there is nothing in the whole compass of art which can be compared for a moment with this massive mystery. We shall in vain attempt to imagine any machine, the work of human hands, which can in any degree compete with this living prodigy. The ordinary duties of sustaining the frame, particle by particle, provision must likewise be made for peculiar emergencies. Suppose a bone to be fractured, the attention of the vital agent appears to be instantly called to the spot of danger; materials are hurried to the scene of the catastrophy; and if the damage be not excessive, very healing operations are straightway commenced for the restoration of the part. 


\section{0}

The most astounding feature in the digestive transactions is, that the very organs which are repairing and renewing the body, are able to repair and renew themselves. The receptacle in which the food undergoes all the necessary preliminary changes, must be renovated from the very aliment which it is its duty to elaborate and prepare. And this same renovation must be effected whilst the organs are in full activity. How wonderfully mysterious is all this!

The county of Caithness is an interesting district for the angler. It is not, however, so fruitful of bold and romantic scenery as other parts of the north of Scotland. It is comparatively level, presenting a great scarcity of trees and shrubbery, and, in some places, has the poverty-stricken appearance of a perfect desert. But a contemplative piscatorian can cull pleasure even from the sternest and most negative features of nature.

The constant succession of bold and rugged mountain scenery, in several of the counties we have just passed over, is one of the greatest sources of pleasure which an angler derives from a ramble among them. They present to his eye almost every possible variation; giving it numerous pathways to the summits of the hills, through gorges, ravines, or almost valleys. Mountains, which have the firmest features and the most fixed forms of nature, are yet of a more variable expression than anything in the world. Lakes, trees, meadows, and men, have moods and changeable expressions ; but mountains, beyond all other natural objects, are subject to moods. 'This is the result 


\section{1}

of lights and shadows. Every change of tempera. ture, every change of day, every change of cloud or sun, is reflected upon the mountains. They are the grand expositors of the atmosphere. Sometimes they stand in a dreamy mood-hazy, indistinct, absentminded. All irregularities seem effaced. The lines of depression or the bulges of rock, are lost, and they lie in airy tranquility, as if the Deity had sloped them from base to summit with an even line. Perhaps the next morning all reserve is gone. They have travelled up towards you. They seem close at hand, and look you right in the face. Every line is sharp, and there is no longer any dreamy expression, but one of solemn and earnest out-looking. There is a dark, dignified, and positive expression, as if they had come to judgment with you. They are the favourite grounds for shadows. They lie patiently still while clouds amuse themselves with painting every form and shape upon their huge and rugged sides, and they even choose to make their own shadows rather than have none. A mountain shadow, when the sun is in the west-a sombre sheet of transparent darkness, cast loosely and mysteriously down from cliff to base-is a very witch with the imagination. One's thoughts play with it-rushing in and out-like swallows in their summer evening sportings.

But no effects are finer than those which are sometimes seen at or near sunset, when the heavens are full of white-gray and blue-gray clouds. The light which reveals them is entirely reflected down from the 


\section{2}

clouds, and from different strata, and with different intensities. It is, of all other lights, that which gives the utmost distinctness in contrast with the most perfect obscurity. The nearest point to you will be black with purple darkness, and swell up unfamiliarly into a grandeur which effaces all your familiarity with it. Whether the mountain is a cloud, or the cloud a mountain-whether there is a change going on, and the rocky top is melting away and mistily exhaling, you cannot tell. But right out against this obscure stands another section, so astonishingly revealed that you can trace its anatomy almost to the minutest line. Every swell or scoop-all the ribs and bones - the petty ridges and hollows-the whole waving surface of a long slope-is as distinct as the wrinkles on one's own hands. Between these extremes, there is every possible gradation. Never long alike in any feature, but changing with the ever-changing cloud, you cannot but feel there is some mysterious connection between cloud mountains and earth and rock mountains. One's imagination sometimes seems to run wild on the subject; and we cannot help asking ourselves, if these airy hills are the spirit-forms which come into visible communion with their yet earthbound brethren? Do these things symbolise the communion of spirits embodied with spirits disembodied? And are these evanescent hues-these strange effects of light-these systems of opal-shadowsanalagous to all those openings and shuttings of the human heart, those lights and darknesses of imagination, which come upon us in the experiences of life? 


\section{3}

Keeping by the coast from the Sutherland side of the county, we meet with the rivers Langwell and Berridale, which join close to the sea, near to the village of Berridale. The Langwell has a fishing range of about eight miles, and is a good stream for salmon and trout at particular seasons of the year. The Berridale has a longer sweep, running fifteen miles, and even more if we make our calculation from its highest springs, situated in the vicinity of Bar Fin. About half-way of its course, it has a connection with Loch-na-Baranach, in which there are some good-sized trout.

In passing from these two rivers, and going north in the direction of the sea-coast, there are no streams of any note till we get to the Wick, with the exception of a few burns or rivulets not worth the angler's notice. The Wick has a run of about sixteen miles, and springs out of the high grounds in the vicinity of Loch Scarmelet, which it flows through, and then enters a large sheet of water called Loch Walter, in which there are a considerable portion of fine trout. The river then flows on for about ten miles, till it enters the British ocean, at the town of Wick.

Five miles north of Wick, is the Water of Wester, which flows through a loch of the same name, and is likewise connected, to the north, with Alterwall Loch, in which there are good-sized yellow trout, and pike of large dimensions. The Wester stream is of no great note. It enters the sea at Sinclair's Bay. Scarlet Loch, and Loch Yarrows, are in this vicinity, and contain good trout. 


\section{4}

The river Thurso, which enters the sea at the town of the same name, is rather a large stream, and stands high in the estimation of modern anglers. It springs out of the lofty grounds, and a series of lakes, situated in the parish of Halkirk, and has a range of full thirty miles. Most all the lakes connected with its higher waters contain trout, and some charr. Lochs More and Calder are the best known, and most frequented by piscatorians. The trout and salmon fishing in the main stream is good, and the accommodation for travellers convenient and respectable. Though the banks of the Thurso are destitute of wood, yet there are very interesting views from many parts of them. We see in the distance, in fine weather, the bright and tranquil ocean, and the variously coloured cliffs of the sea-side, which, when lighted up with the rays of a setting sun, give out forms and outlines of every degree of variation and interest. The sea, in one of its glassy moods is like an extended mirror, save where its surface is rippled by the rapid plunging of the sea-fowl, which, in some localities, are met with in surprising numbers.

The Forss is a good angling stream, of nearly eighteen miles in extent. The most celebrated lochs in the neighbourhood are those of Shurery, Cailm, Scirach, and Sleitile.

There are a few matters connected with an angling tour in the Highland counties, when undertaken on a systematic plan, which we think worthy of notice. What we shall say on the subject is grounded chiefly upon our own experience, with a suitable 


\section{5}

sprinkling of "the wise saws and modern instances" of others. First, we are enthusiastic admirers of pedestrian rambles, not keeping by formal routes, or fashionable places of angling resort, but diving into the nooks and recesses of the country, and going up hill and down dale, just as the crow flies. The greater the physical obstacles in the way the better. When people tell us, there is no road that way, we answer, "There was no road any where till it was made," and off we set. These obstacles call forth energy, and impart great pleasure on being surmounted. A man thinks himself, for a moment at least, a more important personage when he has overtopped a mountain a mile and a half in altitude, or made his way over ten or fifteen miles of dusky moorland, without hearing anything save his own voice-in a stillness which seems to smite his heart with something like fear. These are the kind of movements which brace up a man's nerves like fiddle-strings, and which make him afterwards relish his business or studies with a zest, which a mere lounging or sauntering through a country can never impart. Keeping away from fashionable hotels, or the favourite or pet waters of some particular locality, is the surest method of making an angling tour in such districts as these we have just gone over, both delightful and improving. The mind should be free and unfettered,-in perfect unison with the wild and unbounded scenes of nature around it.

A necessary element in all piscatory exercises and 


\section{6}

amusements is the free use of the limbs. Don't be afraid of them. They will grow every day stronger and stronger, if worked with ordinary judgment. If a man be healthy, pedestrian exercises can seldom be taken in excess. Even when great fatigue is felt, it is a fatigue which does not weaken the general system. On the contrary, a man feels himself strong and active after a severe day's toil. This, of course, is subject to certain conditions; and the true principle of these are,- - that he does not eat too much, nor is too free with his bottle. With respect to eating a full and hearty meal during a long walk, we have seen strong and robust men brought to a state of complete helplessness by such untimely indulgence. The fact is, nature will not bear this double tax on her resources; it is lighting the eandle at both ends. Erery angler will find this to be the case, when perambulating through such a country as the Scottish Highlands. When he has to walk twenty or thirty miles, he should, during his movements, take little solid food, till he has completed his task; and, even then, his meal should be light and spare. We have, ourselves, some twenty-five years ago, often been angling for eighteen hours at a stretch, with, perhaps, about an hour's rest in the interim, and we have been sustained by a little bread and cheese, or a cup or two of cold tea, and without the slightest injury to the body. Even bread alone, sipping (not drinking) water with it, has kept us in a vigorous state to the end of our journey. Of course, there are 
great constitutional differences among men,-some bear regular and systematic guzzling and stuffing better than others,-but, as a general rule, it will be found that nothing enables a man to sustain a fatiguing journey better than spare-very sparediet. This regimen keeps the principle of sensibility in all its pristine vigour; and this is an essential matter. Though we do not know what this principle is, in its abstract nature or essence, yet we all know when it becomes obtuse or blunted by material agencies. It is a principle which keeps soul and body together, and makes them act in complete harmony.

Drink is likewise an important item to be taken into account in pedestrian tours. An angler should never go into the Highlands without a portion of spirits, of some kind, with him; but it should be used as a medicine; - not as a mere stimulant. A man will walk a great deal easier to himself, and at far less wear and tear to his system, when he totally abstains from spirituous liquors. We have seen many scores of anglers, who were always out with their pocket-flasks, and sipping all the day long. This is a bad and senseless system. It deaderis the mind, and destroys its sensibilities to the beauties and sublimities of nature. The grand stimulant to all angling exertions, especially in such a district as the Highlands, should be a zealous cultivation of our tastes for natural and fine scenery. There is such a succession of interesting landscapes-of scenes that are fitted to engross and excite the contempla- 


\section{8}

tive mind-that it seems sadly out of place to drown its energies, and better sympathies and aspirations, with continual patations of stupifying drinks. We effectually, by such a habit, cut ourselves off from all participation in the real and refined pleasures which angling, as an "art, and in such a locality as we are now contemplating, is calculated to afford.

Another essential requisite to comfortable and successful angling tours in the Highlands, is to pay great attention to the feet. Thick shoes or boots, and warm woollen stockings, should be always used. Nathing facilitates a man's easy transit over a mountainous country, and along the rugged banks of streams, better than a sedulous attention to what is here recommended.

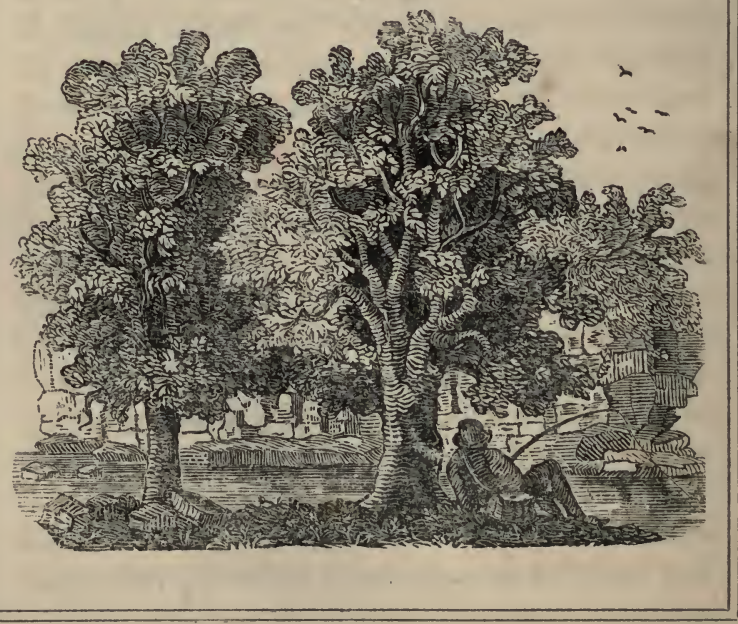




\section{PART IV.}

Treating of Several Angling Streams in Fifeshire, Forfarshire, ANGU,, KINCARDINSHIRE, \&C.

THIs Section of our small work embraces an angling tour of a more limited extent, and of a more tame and subdued scenic character, than that which we have just noticed in the preceding part. The ramble we are now, however, about to enter upon, is, nevertheless, full of natural beauties, and well fitted to impart a fair portion of piscatory pleasure to all who may have leisure time at command to undertake and prosecute it.

We shall take Glasgow, as we have hitherto done, as our point of departure. When we get our rod in hand, and basket on our back, and set fairly out in our journey, it is of moment that we should vigorously brace up our nerves, and freely open out all the arenues of the heart to the genial influences of external nature. This animates and quickens our footsteps, and fully prepares us for our task. Per- 
haps there is no one whose mind is awakened to the feeling of the beautiful and sublimein the external universe, who is fully aware of the depth and intensity of his love, if he have not, at some period of his life, been a denizen of one of our large trading or manufacturing cities. The imaginative power with which he is endowed, will never be more actively and agreeably exercised, than when he is fully placed under the direct influence of rural scenes and natural beauties. Wearied and exhausted in the busy hum of men-the eternal discordant noises of the crowded streets grating harshly on his ear, he will recur with tenfold delight to the recollection of the scenes of the country- to the cries of animals or the songs of birds - to the fall of waters, whether murmuring gently in the "trotting brooks," or dashing fiercely down the rock - to the sounds drawn forth by the winds in their endless courses, whether as sighing and whispering in the leafy woods, or whistling and roaring in all their strength and power. Indeed, a communion with nature is ever interesting. Even difficulties greatly heighten our enjoyments. We should make a point, therefore, on setting out in our fishing excursions, of placing ourselves under the cheering influences of all material objects The man who possesses a keen sensibility to external nature, may almost always say with the poet:-

"I care not, Fortune, what you me deny ;

You cannot rob me of free Nature's grace; 


\section{1}

You cannot shut the window of the sky,

Through which Aurora shows her smiling face;

You cannot bar my constant feet to trace

The woods and lawns, by living streams at eve;

Let health my nerves and finer fibres brace,

And I their toys to the great children leave;

of fancy, reason, virtue, nought can me bereave."

Starting by railway or otherwise from Glasgow, we must make our way to the north side of the Firth, and drop a line into the Carron, which is not, however, of any great value as a mere fishing stream. We have seen, nevertheless, some fine trout taken out of it; and it likewise contains both pike and perch. Its banks, in many spots, are very interesting. The tourist will see that the chain of the Campsie Hills is interrupted by the valley of the Forth. As we take a more northerly direction, it rises still higher into the Ochil Chain, the summits of which rise to above two thousand feet above the level of the ocean. This chain is broken by a narrow valley, through which the Earne and Tay make their way; but between these rivers the hill of Moncrief, and to the north across Angus, the hills of Kinnoul and Liedlaw, continue the chain, though at a very moderate elevation, to the sea at Red Lead. This mountainous tract is said by travellers to resemble very much the district of Auvergne, in the south of France, which is almost universally believed to be a district of extinct volcanoes.

Fifeshire is not a first-rate county for angling. The rivers are the Eden, the Leven, and the Orr; 


\section{2}

and they all flow from west to east, and enter the German Ocean between the Firth of Forth and Tay. It is very convenient to angle all these streams in going by land from Edinburgh to Dundee. In pursuing the main road, through the county, the tourist will cross all the rivers at right angles; and he can ascend such of them as he may find worthy of his attention. Small and middle-sized flies are the most suitable for these Fifeshire streams. Minnow is also a successful bait.

The Eden rises in the Lomond Hills, and flows throw the central vale of the county. It is a slow and languid stream, and the mills, that are situated on its banks, tend to derange the angling in its waters. There are, however, fine white and red trout in it; but they are more readily taken with the minnow than the fly. Pike and eels abound in the deeper parts of the stream, and a considerable portion of salmon are taken near its mouth.

The Leven issues from Loch Leven, and, after running an easterly direction, it receives the waters of the Orr, which spring out of Loch Fitty, and flow into the Firth of Forth at the Village of Leven. It has a course of twelve miles, and, in this short distance, turns forty-five mills for cotton and other things. There are many bleaching works upon its banks; and before these were so extensively established, the river was considered as the finest trout stream in the county. Its fishing capabilities are now, however, considerably impaired. But a fair day's sport may still be obtained, when the waters 


\section{3}

are in proper trim. There is a salmon fishery at its mouth, but the quantity of fish annually taken is not great. It is a curious sight to witness, in May and June, the eels ascending in countless millions up this river to Loch Leven and its marshes, where they remain for an unknown period of time.

The Orr is a tributary to the Leven, and contains very good trout, but they are not numerous. The lover of scenery will not, however, be disappointed by a ramble along its banks.

Loch Leven is a most beautiful lake. Its circumference is about ten miles. It contains two islands, of about two acres in extent, one on which the ruins of Loch Leven Castle stand, and the other called the Inch, where there had been formerly a monas. tery. The Castle is celebrated as being a place where Queen Mary was imprisoned. The fishing on the lake is rented. It abounds with trout of the richest kind, and with considerable quantities of pike, perch, eels, \&c. Trout of a very large size have beein taken out of this sheet of water, of the most extraordinary weight, some say, of eighteen and twenty pounds. These heavy fish have almost invariably been captured by trolling. The pike are also of a very great size; some have been taken of late years, weighing from forty to nearly fifty pounds.

Speaking of pike, we may notice, in passing, that the angling for this fish has become of late years much more general, both in England and Scotland, than formerly. Its history and habits have been 


\section{4}

objects of interest, for many centuries, both to naturalists and anglers;-and, we may add, to cooks likewise. It does not appear that the pike was known to either the Greeks or Romans;-at least Aristotle and Pliny do not speak of it. The first author who treats of it, is Ausonius, who flourished about the middle of the fourth century, and who does not appear to have entertained very favourable opinions of either the kindly dispositions, or gastronomic excellencies of the fish. He holds him forth in a poetic strain under the name of Lucius.

"Lucius obscurus ulva lacunas

Obsidet. His nullos mensarum lectus ad usus,

Fumat fumosis olido nidore popinis."

"The wary luce, midst wrack and rushes hid,

The scourge and terror of the scaly brood,

Unknown at friendship's hospitable board,

Smokes 'midst the smoky tavern's coarsest food."

The largest pike ever taken in Scotland, or in England either, is nothing eompared with the one which was caught in the vicinity of Manheim, in the year 1497. He weighed three hundred and fifty pounds, and measured nineteen feet. Besides this, he bore a Greek inscription appended to his muzzle, containing these words:- "I am the fish that was put into this pond by the hands of the Emperor Frederic the Second, on this $3 d$ day of October, 1262 ;"- -thus, making the age of the monster two hundred and thirty-five years. The skeleton of this fish is still to be seen in the Museum of Manheim. 


\section{5}

Lord Bacon maintained in his day, that the utmost limit of the life of a pike was forty years.

Of the ravenous habits of the fish much has been written. The author of British Fish and Fisheries says :- "Shrouded from observation in his solitary retreat, he follows with his eye the motions of the shoals of fish that wander heedlessly along; he marks the water-rat swimming to his burrow, - the ducklings paddling among the water-weeds, - the dab-chick aud the moor-hen leisurely swimming on the surface; he selects his victim, and, like the tiger springing from the jungle, he rushes forth, seldom indeed missing his aim;- there is a sudden rush, circle after circle forms on the surface of the water, and all is still again in an instant."

But though rapacious to a proverb, yet the pike has his own likes and dislikes;- - there are tasty bits of food that are said to be keenly relished by him. Among these, writers state the following:-A swan's head and shoulders, a mule's lip, a Polish damsel's foot, a gentleman's hand, and a lady's too, when very soft and plump, tender kittens before their eyes open, and the fleshy parts of a calf's head.

The opinions and practices relative to the pike as an article of food, have been various and conflicting. In some districts of France he is viewed with loathing, while at Chalons-sur-Saone, he is esteemed one of the first luxuries. In Italy pike are seldom touched, and the Spaniards entirely rejeot him. In Germany he has a high reputation in many districts. In England, in the thirteenth century, pike was so 
dear that few could purchase it; Mr. Yarrell says, it was double the price of salmon, and ten times higher than that of either turbot or cod. "In 1466, pike was one of the chief dishes in the High Church festivals given by George Neville, Archbishop of York. In Henry the Eighth's time those watery tyrants fetched as much again as household lamb in February, and a very small pickerel would sell higher than a fat capon."

The North Queich, and the South Queich, are the two chief feeders of Lochleven. There is good fishing in both these streams, except in very dry and sultry weather. We have found all kinds of winged flies, of a lightish colour, most successful in these waters.

The antiquities of Fifeshire are numerous, and its ecclesiastical remains and history interesting. There is a great number and variety of vestiges of the Caledonian and Pictish inhabitants, and of their Roman and Danish invaders. There are also many military forts, mounds of encampments, groups of Druidical lithoi, cairns, tumuli, barrows, stone coffins, skeletons, Celtic sepulchral urns, spears and arrow heads of flint, swords, and battle-axes of brass and bell-metal," crosses, fonts, beads, Roman coins, \&c. All these are very interesting to such anglers as have a taste for antiquarian researches.

Before the angler quits the rivers of Fifeshire, he should, if he have any taste for learning and philosophy, pay a visit to the University of St. Andrews. There is much to interest a reflective mind in this 
ancient seat of scholarship. Besides, there is a legend connected with the history of the "Gentle Craft," emanating from this celebrated place. In a work, published at Liege, in Belgium, 1689, called "The Lives of the Holy Fathers," we find an account given of a St. Malc, who visited St. Andrews about the tenth century, and who performed a great miracle upon the fish of the Tay, for the purpose of strengthening, among the rude inhabitants of the district, a belief in his divine mission to teach the truths of Christianity. There are accounts still extant of similar legends in other parts of Scotland, as well as in England. We have a notable story connected with one of our early English bishops-the Bishop of Chichester-which shows the common practice of early times of ascribing miracles to fish. The first bishop sent from Rome to this part of England, seeing the people eat greedily of the sandeels caught near the place, sent information to St. Peter's, that the people here eat serpents. This horrified the Holy See, and a message was sent back, that if they would refrain from such a repulsive and heathenish custom, they should for the future be amply supplied with real fish, and that of the very first quality. The people consented; the influence of the Holy Pontiff was immediately put into requisition, and a most sumptuous supply of fish of every kind was for a long period most miraculously served out to the benighted but faithful people.*

* History of Chichester. 


\section{8}

The Hermit's Fish-Pond, now remaining in a valley, near Glastonbury, exhibits the materials of a legendary tale about fish. In this pond there were three fishes, of which St. Neot had Divine permission to take one, and only one, every day, with an assurance that the supply should never be diminished. Being afflicted with a serious indisposition, his disciple, Barius, one day caught two fishes, and having broiled one, and boiled the other, placed them before him. "What hast thou done," exclaimed St. Neot, "lo! the favour of God deserts us; go instantly, and restore these fishes to the water." While Barius was absent, Neot prostrated himself in earnest prayer, till he returned with the intelligence that the fishes were disporting themselves in the pool. Barius again went and took only one fish, of which St. Neot had no sooner tasted than he was restored to perfect health.*

We have, indeed, multitudes of legends connected with fish and fishing scattered over the theological literature of France, Italy, Spain, and Germany. The legend of St. Anthony, of Padua, is, unquestionably, the most striking and ingenious of all the pious effusions of this kind. The sermon commences with, "My dearly beloved fish," and goes on, at great length, and with much eloquence, to show how fish had in all ages been the especial favourites of heaven; that they lived in an element which

* History of St. Neots, by the Rev, G. C. Graham. London, 1838. 


\section{9}

secured them from the many troubles and evils which befell terrestrial animals; that they had been the chosen medium through which many of the gospel rites and doctrines had been made known to mankind; and that now he had assembled them together for the purpose of teaching a great religious and moral lesson to the unbelieving and wicked people around him. And the saint concludes his discourse in the following words: "In what dreadful majesty-in what wonderful power-in what amazing providence, did God Almighty distinguish you among all the species of creatures that perished in the universal deluge: you only were insensible of the mischief that laid waste the whole world. All this I have told you, ought to inspire you with gratitude and praise. You cannot employ your tongues, nor express your gratitude in words; make at least some sign of reverence; bow yourselves according to the best of your capacity; express your thanks in the most becoming manner that you are able; and be not unmindful of all the benefits bestowed upon you."

We are told that St. Anthony had no sooner left off speaking than the fishes, as though they were moved by reason, bowed down their heads in profound humility, and manifested the most lively joy at his address. The story adds, that after many heretics, present on the occasion, had been converted, the saint gave his benediction to his finny auditory, and dismissed them.

Lady Morgan describes a picture in the Borghese 
Palace, at Rome, which represents St. Anthony delivering this address. Her Ladyship says, "The salmon look at the preacher with an edified face, and a cod, with his upturned eyes, seems anxiously looking out for new light." There is likewise a splendid picture on the same subject, by Salvator Rosa, now in the collection at Althorpe House, Northamptonshire.*

Saint Patrick is the patron saint in Ireland for fish and fishers. The legend tells us that the holy man having an irresistible desire for some flesh meat, obtained a piece of pork, and hid it. An apparition had its eye on his movements, and struck him with remorse of conscience. He repented; and, as a proof of the sincerity of his contrition, an angel turned this piece of pork into some fine rich fish!

On quitting Fife, the angler will cross the Firth of Tay, a most splendid inlet, nearly twenty-four miles in length, and from two to four in breacuth. When viewed from any commanding eminence, it is a most interesting sight; presenting the bold and rocky coast of Fifeshire on the south, and on the north the fine Carse of Gowrie, a rich plain that stretches from the Firth to the foot of the Leidlaw Hills, affording the tourist a magnificent landscape, comprehending the deep Bay of St. Andrews, and the churches of this ancient city, which are distinctly seen in the distance.

* This legend is but little known in England, even among Catholies; but it may be seen in every bookseller's window. in Rome, at the present day. 


\section{1}

The chief angling rivers in the county of Forfarshire are the North and South Esk, the Isla, and the Tay. The two last have been noticed under Perthshire. The North and South Esk are fine, clear, sparkling streams, and abound with a great quantity of trout, though not of very large size. The rivers have fine gravelly beds, and their rippling streams are most delightful to the fly-fisher. The salmon here are of excellent quality, and have, on some occasions, been caught of a most stupendous size. A gentleman in the neighbourhood, in 1829, killed one with fly, fifty-four pounds. The fish struggled hard for fire hours. Had not the streams been very favourably situated, his capture could not have been effected.

The North Esk issues from Lochlee, which receives its waters from the mountain torrents of the Grampians. The river flows south east, and is augmented in its progress by many smaller streams, all of which are full of fish, and afford excellent sport with the worm, in the hot and dry days of summer, when it is too clear for the fly in the main river. When the North Esk becomes the northern boundary of the county, and receives the West Water and the Water Cruick, it flows a south easterly direction, through a very fertile and delightful country, and falls into the sea about three miles north of the town of Montrose. It is subject to great and impetuous inundations; and, in every part of its course, you may see deep ravines in the bed of the river, produced from the overwhelming floods which pour 


\section{2}

down from the sides of the Grampian Mountains. As the waters dash from rock to rock, the effect is grand and romantic in the extreme; and nature has been greatly assisted by the artificial elegancies which Lord Gordon has introduced in many localities in the river.

The higher waters of the North Esk are composed of the streams called the Lee, the Mark, and the Brany. In its progress of fifty miles in extent, the waters of the Effock, Tarf, Turret, and Keeny, are poured into it. We have known very large trout taken out of some of these streams by trolling; and, when the fish are in a taking mood, any thing in the shape of a fly will satisfy them. All these streams flow through districts that are exceeding interesting and beautiful.

One of the striking features which marks a ramble among the rivers in this eastern section of Scotland, somewhat different from an excursion among the mountain streams of the Highlands, is the prevalence of copse-wood, hedge rows, and limited patches of ornamental timber. These relieve the general landscape mightily; and, what is of more moment, they afford places of shelter for several species of birds, whose notes fall upon the ear of the traveller with a ravishing sweetness. The notes and cries of the feathered creation have an especial adaptation to the localities they frequent. In the wild and solitary glens and morasses of the Highlands, how strikingly in unison with external nature, and one's own feelings, are the shrill whistle 


\section{3}

of the curlew, and the plaintive tenderness of the plover! Sounds of this kind, in such localities, make sadness pleasingly sad, and desolation more desolate. When we come into districts where copse and woodland covers prevail, we have the clear notes of the mavis and merle, which are in admirable keeping with the active and busy scenes of human life and industry, and with the blossoms, and flowers, and shrubs, which adorn the earth's surface, when subjected to the labour of man. Such sweet notes make rusticity more rustic, and give rise to the most soothing emotions which luxuriant nature can produce on our inward frame.

The South Esk issues from the north-west summit of the Grampians, out of a lake of the same name, situated in the parish of Clova. It is from sixty to seventy miles in extent, and falls into the sea at Montrose. Near to its source, are Lochs Wharral and Brany, which contain good trout, as well as pike and perch. Very large trout have been occasionally taken in those still waters by trolling, and some even with the fly. For the first twenty miles of South Esk, the generality of the fish found in it are small; and, in fine, clear, summer weather, the waters get too limpid, and too much reduced, for successful exploits with the rod. But after rain, there seems no end to the number of trout that can be taken in it. We have found the angling for about ten miles above the Town of Brechin, to be the best portion of this river. There 


\section{4}

are fine streams, and stretches of still water, where large fish are always to be met with.

The tributaries of the South Esk, are the Whitewater, the Carity, the Lemno, the Noran, and Pow waters. There is likewise the Prosen, which is a good stream, and has three feeders,- - the Lednathy, Glenoig, and Glenlogy, -in all of which there are countless numbers of small trout.

The Town of Brechin is a place worthy of the angler's notice. In the church-yard, near the Cathedral, is one of those round towers, which have excited among antiquarians so much discussion, and the origin and use of which have not yet been satisfactorily accounted for. Brechin Castle is situated at the top of a precipice, and is separated from the town on the east and west by a deep ravine; its south base is washed by the waters of the South Esk, which forms here a most enchanting piece of water. It was in this castle that Sir Thomas Maule defied the forces of Edward III., until he was killed by a stone thrown by an engine, when the garrison surrendered to the English.

A short distance from this place the river presents a lovely appearance, chiefly from the softening shades of aerial perspective, which opens to the view as we approach a little village by its banks. Every turn or bend of the waters presents a beautifully varied landscape. Elevated masses of rock, and here and there some old building perched on their summits, greatly enhance the natural beauties of the locality, and rivet us as by enchantment to the spot. 


\section{5}

The ecclesiastical and antiquarian remains are interesting in Forfarshire. Near to Forfar is a Druidical circle; monumental stones with curious sculptures; and cairns containing coffins and urns. Not far from Cupar-Angus is King Arthur's Stone or Monument, connected with a cairn which tradition affirms contains the bones of this legendary Prince. Here are Glammis, and Dunsinane, mentioned in Shakspere's tragedy of Macbeth, where he says,-

"By Sinel's death I know I'm Thane of Glammis."

This was the locality which witnessed the usurper's principal movements. On the hill of Dunsinane was the Castle of Macbeth, from which he sallied, when, in the words of the poet, he exclaims,-

"I will not yield

To kiss the ground before young Malcolm's feet, Though Birnam wood be come to Dinsinane, And thus opposed be of no woman born."

\section{"Lay on Macduff!}

And damned be who first cries hold, enough."

Two mounds of earth, called Duff's Know, and Bellie Duff, contain, according to popular tradition, the mortal remains of Macduff, and of his enemy Macbeth. At Glammis there is a large monumental stone, commemorative of the assassination of King Malcolm II.; whose murderers were drowned in making their escape in the night across the frozen loch of Forfar. There are also many curious Caledonian, Druidical, Scandinavian, Roman, and monastic antiquities, scattered over different parts of the 


\section{6}

county; such as stone coffins, urns in sepulchral cairns, battle-axes, swords, sculptured stones, Roman coins, and other similar articles of ancient times.

Lunan Water flows through three lakes, Restenet, Rescobie, and Balgavies. These sheets of still water contain only pike, and a few perch. The Vinny, which is a feeder of the Lunan Water, has a fair portion of trout in it, as well as its parent stream.

In Kincardinshire, the Bervie is a good red water, and has a run of about seventeen miles. There quantities of fine trout are taken out of it. The anglers who frequent the river give a decided preference to light-coloured flies, for the early months of the fishing season, and dark ones towards its close. The Carron and Towie waters are likewise fair streams for trouting. 


\section{N D EX.}

\begin{tabular}{|c|c|c|c|c|c|c|c|c|}
\hline \multirow{2}{*}{\multicolumn{2}{|c|}{ Allan Water, }} & \multicolumn{3}{|r|}{ PAGR } & \multicolumn{4}{|r|}{ PAGE } \\
\hline & & - & - & 30 & Bervidale, & - & *. & 173 \\
\hline Ale, & - & - & - & 31 & Balnagown Wa & ter, & - & 151 \\
\hline Almond, & & - & - & 39 & Brary, - & - & - & 192 \\
\hline Avon, & - & - & - & 54 & Chapelthorpe St & tream, & & 20 \\
\hline Annan, & - & - & - & 61 & Corse-cleugh St & tream, & - & 20 \\
\hline Ayr, & - & - & & 92 & Caalstone Wate & & 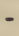 & 39 \\
\hline Auldhou & se Bur & & & 95 & Clyde, - & - & & 44 \\
\hline Allan, St & irling & hire, & - & 105 & Croak Burn, & - & & 44 \\
\hline Ary, & - & - & - & 106 & Culter Water, & - & & 46 \\
\hline Awe, & - & - & - & 109 & Crane Loch, & $\infty$ & & 49 \\
\hline Almond, & Argyl & shire & & 117 & Castle Loch, & L & & 64 \\
\hline Aven, & - & - & & 136 & Crawick Water & & & 69 \\
\hline Ault-gra & $\mathrm{d} \mathrm{W}$ & ter, & & 151 & Cluden Water, & - & & 73 \\
\hline Alness II & ater, & - & - & 151 & Cairn Water, & - & & 73 \\
\hline Biggar V & Vater, & - & & 10 & Cree Water, & - & & 87 \\
\hline Barthwic & $\mathrm{k} W \mathrm{a}$ & er, & & 30 & Coyle, - & - & 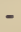 & 92 \\
\hline Blackadd & & - & - & 36 & Caaf Water, & - & & 95 \\
\hline Biel Wat & er, & - & & 39 & Cart, White, & - & & 95 \\
\hline Black Bu & $\mathrm{rn}$ & - & & 46 & Cart, Black, & - & & 95 \\
\hline Blandeno & $\operatorname{ch~W}$ & ter, & & 87 & Cona, - & - & & 114 \\
\hline Brother & Loch, & - & & 95 & Crenan, & - & & 114 \\
\hline Black Lo & ch, & - & & 95 & Clugh, & - & & 115 \\
\hline Buie Wa & ter, & - & & 114 & Coinich, & - & & 116 \\
\hline Braan, & - & - & & 122 & Col, & - & & 116 \\
\hline Buttersto & ne Lo & & & 122 & Carradale, & - & & 116 \\
\hline Bracklin & Burn, & - & - & 125 & Crossaig, & - & & 116 \\
\hline Bucket, & - & - & & 129 & Claonaid, & - & & 116 \\
\hline Brony, & - & - & & 132 & Clunie Water, & - & & 128 \\
\hline Bogie, & - & - & & 133 & Calpie, - & - & & 130 \\
\hline Bruach, & - & - & & 139 & Calder Water, & - & - & 134 \\
\hline Beauly, & - & - & - & 143 & Crombie Water & & & 136 \\
\hline Bervie, & - & - & & 196 & Cawdor Burn, & - & & 139 \\
\hline Brara, & - & - & & 162 & Clannie, - & - & 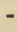 & 143 \\
\hline & ater, & - & & 162 & Carity, - & - & & 194 \\
\hline Borgie, & - & - & 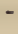 & 164 & Carron (Forfar) & & - & 196 \\
\hline
\end{tabular}




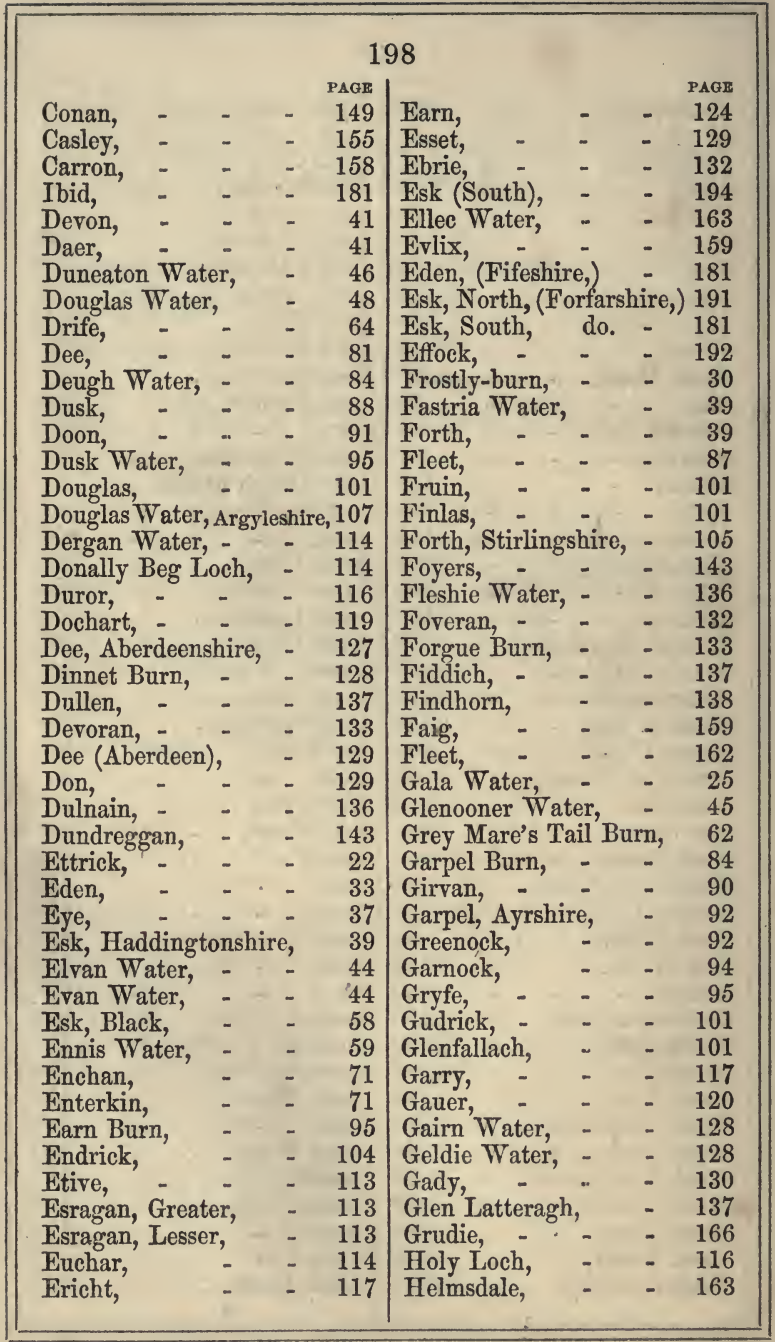


199

\begin{tabular}{|c|c|c|c|c|}
\hline & & PAGE & & PAGE \\
\hline Halladale, & - & 163 & Loch Houie, & 84 \\
\hline Hope, - & - & 166 & Loch Skae, & 84 \\
\hline Inveruglass, & - & 101 & Loch Cree, & 87 \\
\hline Isla, - & - & 122 & Luce Water, & 87 \\
\hline Inchard, & - & 166 & Loch Darnal, & 88 \\
\hline Inver, & - & 156 & Loch Maberry, & 88 \\
\hline Jed, & - & 31 & Loch Chirmony, & 88 \\
\hline Kale, - & - & 32 & Loch Moam, & 88 \\
\hline Kirtle Water, & - & 60 & Loch Doon, & 91 \\
\hline Kinnel, - & - & 64 & Loch Braden, & 92 \\
\hline Kello Water, & - & 70 & Loch Dercleugh, & 92 \\
\hline Ken, , - & - & 83 & Loch Findas, & 92 \\
\hline Kevach Burn, & - & 95 & Lugar, - . & 92 \\
\hline Kelvin, . - & - & 99 & Loch Kilbirnie, & 95 \\
\hline Keith, & - & 123 & Loch Castlesemple, & 95 \\
\hline Keltie, & - & 125 & Lugton, - - & 95 \\
\hline Knaig, & - & 125 & Loch Goin, & 95 \\
\hline Kelloch, - & - & 126 & Long Loch, & 95 \\
\hline King Edward' & s Wate & 133 & Levern Water, & 95 \\
\hline Kinloch, - & - & 166 & Loch Lomond, & 99 \\
\hline Kyle of Tongu & & 166 & Leven Water, & 100 \\
\hline Kyle of Durne & & 166 & Luss, - & 101 \\
\hline Kearving, & - & 166 & Loch Sloy, & 105 \\
\hline Kirkaig, - & - & 156 & Loch Arrochar, & 105 \\
\hline Keeny, - & - & 192 & Loch Ard, & 105 \\
\hline Lyne, & - & 11 & Loch Fin, - & 106 \\
\hline Leithen, & - & 14 & Loch Awe, & 108 \\
\hline Leader, & - & 26 & Loch Etive, & 108 \\
\hline Lymy-cleugh & Burn, & 30 & Liver, - & 113 \\
\hline Leet, & & 35 & Loch Crenan,- & 114 \\
\hline Leith, & & 39 & Loch Leven, & 114 \\
\hline Little Clyde, & & 44 & Loch Scauradale, & 114 \\
\hline Logan, & & 53 & Loch Trallaig, & 114 \\
\hline Liddal, & & 59 & Loch Nell, & 115 \\
\hline Locher, & & 66 & Loch Feochan, & 115 \\
\hline Loch Ưrr, & & 80 & Loch Killyheran, & 115 \\
\hline Loch Dee, & & 81 & Loch Lihnne, & 115 \\
\hline Loch Ker, & & 83 & Loch Eil, - & 115 \\
\hline Loch Grannoc & & 84 & Loch Sunart, & 115 \\
\hline Loch Darnal, & & 84 & Loch Shiel, & 115 \\
\hline Loch Lochinb & ck, & 84 & Laroch, - & 116 \\
\hline Loch Glentoo, & & 84 & Leven, & 116 \\
\hline Loch Roan, & & 84 & Loch Eck, & 116 \\
\hline Loch Brack, & & 84 & Loch Fad, & 117 \\
\hline Loch Barscobe & & 84 & Loch Ascog, & 117 \\
\hline
\end{tabular}




\begin{tabular}{|c|c|c|c|c|c|}
\hline \multicolumn{6}{|c|}{200} \\
\hline & & PAGE & & & PAGE \\
\hline Loch Jorsa, &. & 117 & Loch Trevie, & - & 137 \\
\hline Loch Tanna, & - & 117 & Loch Dallas, & - & 137 \\
\hline Loch Tay, & - & 117 & Loch Noir, & - & 137 \\
\hline Lyon, - & - & 117 & Lock Rheninver, & - & 137 \\
\hline Lacchay, - & - & 119 & Loch Moy, & & 139 \\
\hline Loch Batha, & - & 120 & Loch Bruach, & - & 139 \\
\hline Loch Lydoch, & - & 120 & Loch-an-Darb, & - & 139 \\
\hline Loch Ard, & - & 122 & Loch Linnhe & - & 139 \\
\hline Loch Craiglush, & - & 122 & Loch Lachy, & - & 141 \\
\hline Loch of the Lows, & & 122 & Loeh Oich, & - & 141 \\
\hline Loch Rotriel, & - & 122 & Loch Gorm, & - & 144 \\
\hline Loch Oishnie, & & 122 & Loch Nambrodarg, & & 144 \\
\hline Loch Cluny, & - & 122 & Loch Carnabatan, & - & 144 \\
\hline Loch Drumellie, & - & 122 & Loch Wharral, & - & 193 \\
\hline Loch Earn, & - & 124 & Loch Brany, & - & 193 \\
\hline Loch Voil, . & - & 124 & Loch Restenet, & - & 196 \\
\hline Loch Lubnaig, & - & 124 & Loch Rescobie, & - & 196 \\
\hline Loch Katrine, & - & 125 & Loch Balgavies, & - & 196 \\
\hline Loch Achray, & - & 125 & Loch Fleet, & - & 162 \\
\hline Loch Vennachar, & - & 125 & Loch Buie, & - & 162 \\
\hline Loch Watston, & - & 125 & Loch Furan, & - & 162 \\
\hline Loch Maghaig, & - & 125 & Loch Tubernach, & - & 162 \\
\hline Loch Brodichan, & - & 128 & Loch Brara, & - & 162 \\
\hline Loch Dhu, & - & 128 & Loch Macayn, & - & 163 \\
\hline Loch Muick, & - & 128 & Loch Baden, & - & 163 \\
\hline Loch Cannord, & - & 128 & Loch Leam-na-Cla & aven, & 163 \\
\hline Loch Leys, & - & 128 & Loch Carr, & - & 163 \\
\hline Loch Dawan, & - & 128 & Loch-in-Ruar, & - & 163 \\
\hline Livet Water, & - & 136 & Loch-na-Coarach, & & 163 \\
\hline Lossie, - & - & 137 & Loch-na-Sealy, & - & 163 \\
\hline Lochly Burn, & - & 137 & Loch Balligill, & - & 163 \\
\hline Lennoch Burn, & - & 137 & Loch Arron, & - & 163 \\
\hline Lemno, - & - & 194 & Loch Naver, & - & 163 \\
\hline Lunan, - & - & 196 & Langdale Burn, & - & 164 \\
\hline Lochy, - & - & 140 & Loch Elam, & - & 164 \\
\hline Loch Muckle, & - & 132 & Loch Cragie, & - & 164 \\
\hline Loch Strathbeg, & - & 133 & Loch Loaghal, & - & 164 \\
\hline Loch Spey, & - & 134 & Loch Dionard, & - & 166 \\
\hline Loch Inch, & - & 136 & Loch Borralie, & - & 166 \\
\hline Loch Alvie, & - & 136 & Loch Crasbole, & - & 166 \\
\hline Loch Morlich, & - & 136 & Loch Loxford, & - & 166 \\
\hline Loch Rothiemurcus & & 136 & Loch Stack, & - & 166 \\
\hline Loch Pittenlish, & - & 136 & Loch Leadvuam, & - & 166 \\
\hline Loch Garten, & - & 136 & Loch Dhu, & - & 166 \\
\hline Loch Bulg, & - & 137 & Loch Cail, & $1-$ & 166 \\
\hline
\end{tabular}




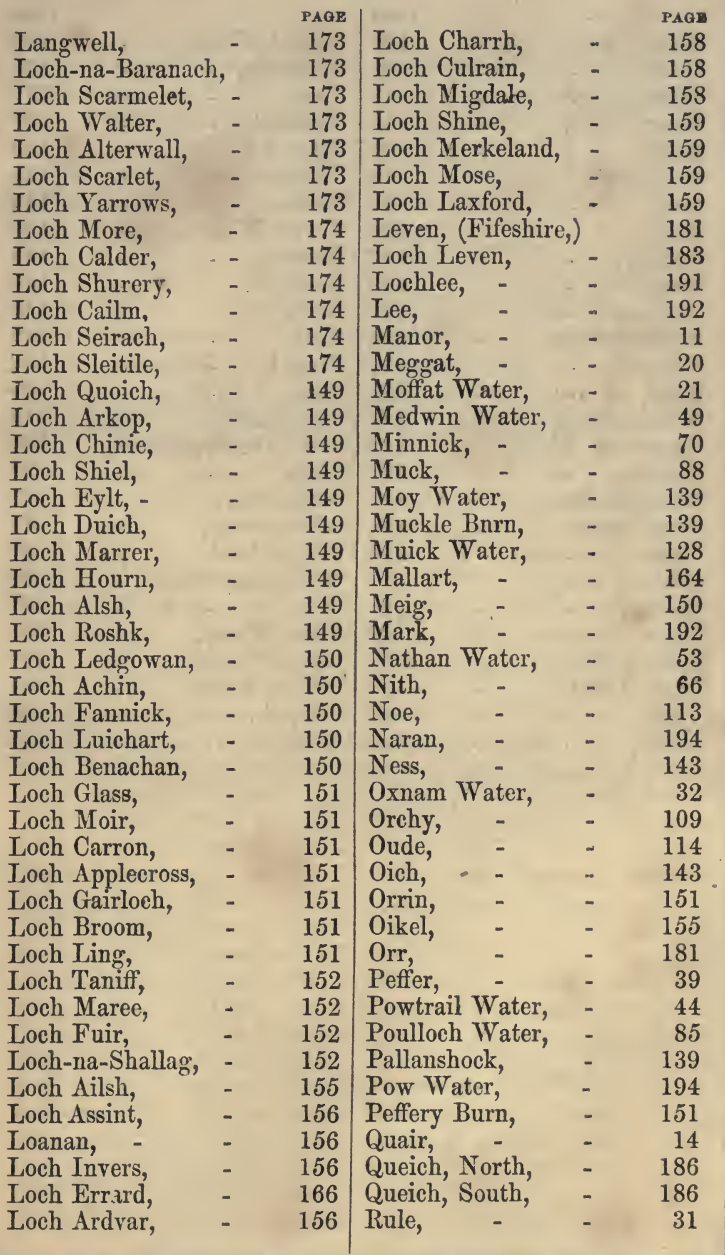




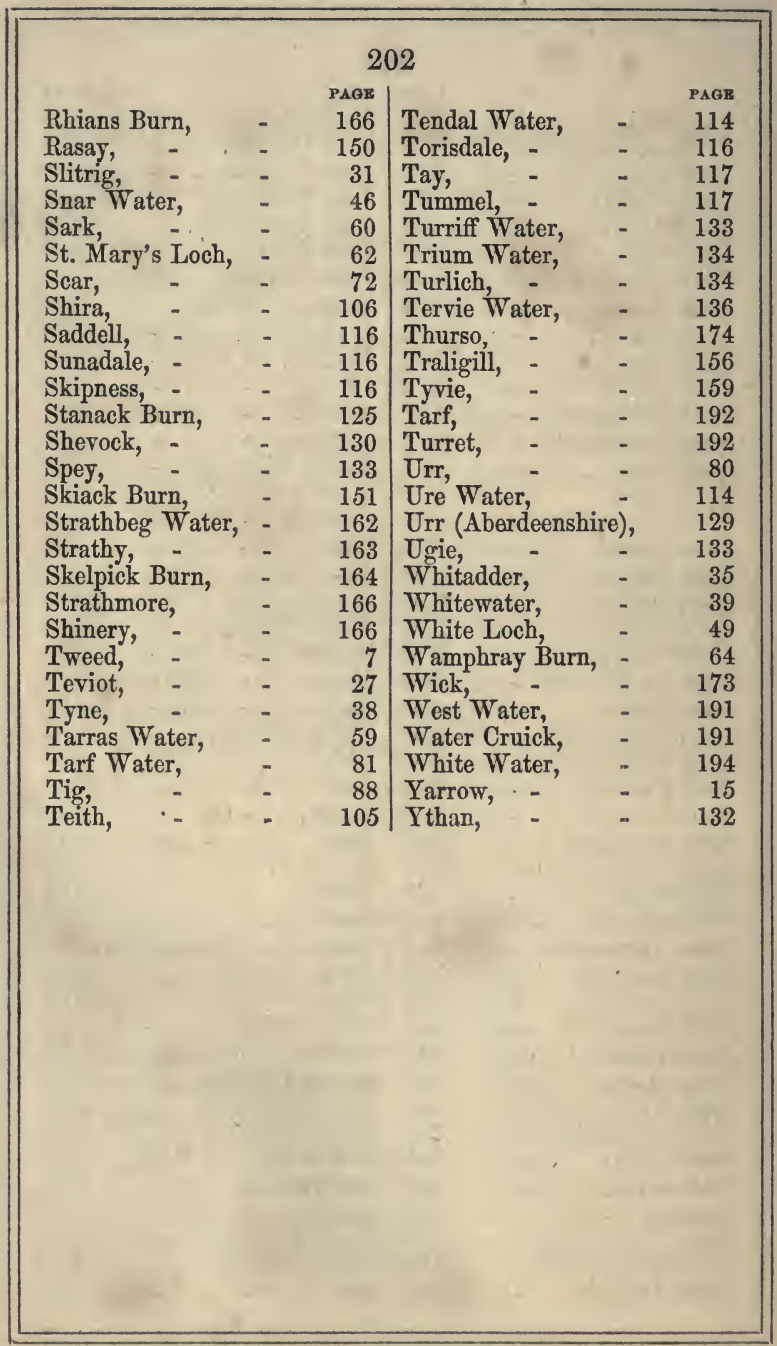




\section{3}

LIST OF FISHING-TACKLE DEALERS IN LONDON.

\section{Those marked with an * are also Mannfacturers.}

*Ainge \& Aldred, .....126, Oxford Street.

*Wm. H. Alfred, ..... .54, Moorgate Street.

John Anderson, ....... 71, Long Acre.

John Jas. Basin,....... 8, Dunean Place, London Fields.

*John Bernard, .......4, Church Place, Piccadilly.

John Billington,........93, Charlton Street, Somers Town.

*William Blacker, ......54, Dean Street, Soho.

*Geo. Bowness \& Son, .. 12, Bell Yard, Temple Bar.

*Geo. Bowness, Jun ... . 33, Bell Yard, Temple Bar.

Wm. Brain,...........Park Side, Knightsbridge.

Edw. Brander,........27, Wormwood Street, Bishopsgate.

*John Cheek, .........132 Oxford Street.

Robert Cove, ........5, Oakley Street, Lambeth.

*Joseph Clark,.........11, St. John's Lane, Clerkenwell.

*E. Creed, ...........33, Wilderness Row, Goswell Street.

* Joseph Cureton,.......48, Snows Fields, Bermondsey.

E. Davis ...........60, Hungerford Market.

H. Dixon,............172, Fenchurch Street.

Wm. Edmonds, .......15, East Road, City Road.

*Chas. Farlow,.......221, Strand.

*John Farlow, ........5, Crooked Lane.

Marco Fernandez,.......2, Devonshire Sq. Bish. Gut Mercht.

*Alfred Gould.........36, Great Marylebone Street.

*Chas. Holmes, .......115, Fetter Lane.

*John Spear Holroyd....59, Gracechurch Street.

Thos. Jackson, .........220, Bethnal Green Road.

*Mrs. Jones,..........111, Jermyn Street, St. James.

Henry Joy, .........6, Opera Areade, Pall Mall.

*Giles Little, .........15, Fetter Lane.

Barnett Myers, ........18, Crutchfriars.

*Samuel Roberts, ...... 10, Crooked Lane.

Thos. Roblow .........30, Upper Marylebone Street. 


\section{4}

John Sanderson.......9, Blackfriars Road.

*Henry Turpin, ........124, St. John Street Road.

*Ustonson \& Peters, ....48, Bell Yard, Temple Bar. George Eaton,........6 and 7 Crooked Lane, City. Wm. Bartlett \& Sons, ...37, Gresham Street, City. G. Chambers \& Co.,...14A, Gresham Street, City. J. J. W. Gutch \& Co.,...50,King WilliamSt. City, Hook Maker. Kirby, Beard \& Co.,....46, Cannon Street, City. James Mills........7, East Cheap. Abel Morrall,........134, Upper Thames Strect. James Pardow, ......44, Basinghall Street. Geo. Tarney,......... 106, Wood Street, City. Henry Wallur,....... Gresham Street, West.

\section{A FEW PROVINCIAL FISHING-TACKLE DEALERS.}

Murray, ............. Arran Quay, Dublin.

Martin Kelly, ..........Sackville Street, Dublin.

W. K. Rogers, Esq., .....Cork.

Hacket,........... Great George Street, Cork.

O'Shaughnessy, ........ Limerick.

J. D. Dougall, .........Argyle Arcade, Glasgow.

Forrest,...............Kelso.

Douglass, ........... Edinburgh.

Flinn, .............Worcester.

Frederick Alliers, ...... St. John's, Worcester.

John Edmondson, ...... Liverpool.

Mr. Spalding.......... Near the Bridge, Richmond, Surrey. Mr. E. Lees,......... At the sign of the Salmon, 5, Sussex Street, near Broadmarsh, Nottinghamshire.

Mr. Philip Pulman, .....Axminster.

Mr. G. P. R. Pulman, . . . Crewkerne.

Mr. Holroyd, ........ Cookham, Berks. 


\section{5}

WORKS PUBLISHED BY MR. BLAKEY.

THE ANGLER'S COMPLETE GUIDE TO THE RIVERS AND LAKES OF ENGLAND AND WALES. London, 2s., 1853. "An interesting little volume."-Sun. "An excellent guide."-John Bull. "The sons of patience will find this volume worth their perusal."-British Banner.

HINTS ON ANGLING; with an account of the Angling Rivers of France and Belgium, (under the signature of Palmer Hackle). London, price 9s. 1846. "The work is well written."-Athenaum. " A work of great literary abiliity."Morning Post. "An elegant and charming volume."-Tait's Magazine. "The author is a genuine brother of the craft; and his trips along the French rivers are full of picturesqueness and detail of life as well as Angling."-New Monthly Magazine. "A nicely got up book."-Literary Gazette.

HISTORY OF THE PHILOSOPHY OF MIND、 4 vols. 8vo. £3. London, Longman \& Co.

TEMPORAL BENEFITS OF CHRISTIANITY. 8vo., 9s. 1849. London, Longman \& $\mathrm{Co}$.

A HISTORICAL SKETCH OF LOGIC, London, 12s. Bailliere. 1851.

ESSAY ON LOGIC. London, 2d edition. 5s. 1848.

AN ESSAY ON MORAL GOOD AND EVIL; AND OF THE FREEDOM OF THE DIVINE AND HUMAN WILLS. L London, 2d edition, 8s. 1848.

HISTORY OF MORAL SCIENCE. 2 vols., London, $2 \mathrm{~d}$ edition, £1 1s. 1836.

LIVES OF THE PRIMITIVE FATHERS OF THE CHURCH, with Plates. London. 9s. 1842. 


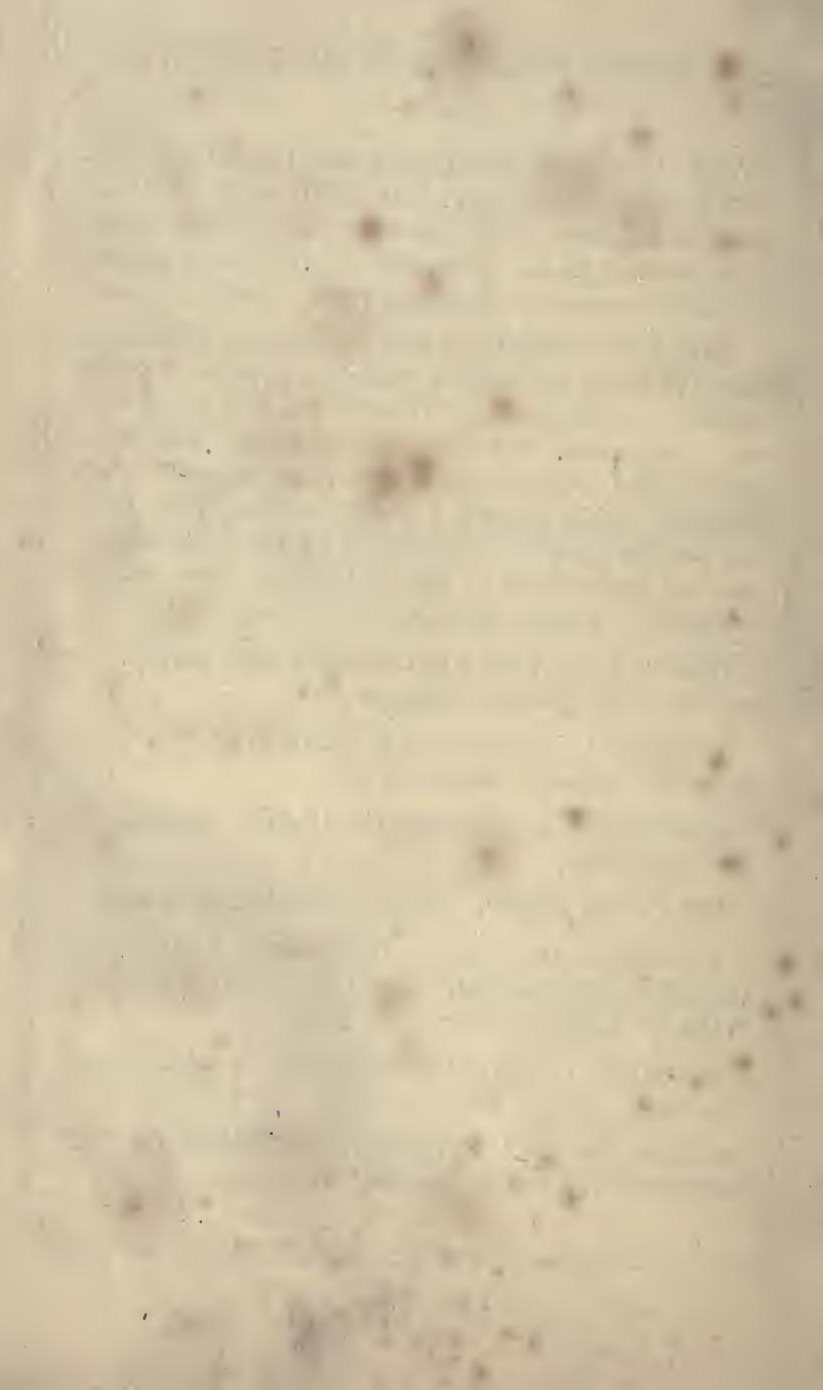




YB Ina7s 
